\title{
Estructura financiera del tribunal de la Inquisición de Teruel: La receptoría de Juan Claver (ejercicio 1487)*
}

\author{
Manuel Sánchez Moya** \\ Investigador Independiente \\ ORCID ID: https://orcid.org//0000-0003-1530-0906 \\ Miguel Ángel Motis Dolader*** \\ Universidad San Jorge \\ ORCID ID: https://orcid.org/0000-0003-2471-8335
}

En el presente artículo analizamos el primer Libro de la Receptoría de Juan Claver, del tribunal de la Inquisición del distrito de Teruel, relativo al ejercicio fiscal del año 1487 , cuyo balance refleja un equilibrio contable entre los ingresos y los gastos. Se estudian, en primer término, los bienes muebles e inmuebles subastados por el receptor, así como las rentas percibidas de los paterfamilias de dieciocho casas -de los que se realiza una breve semblanza biográfica-, incluyendo un epígrafe genérico sobre los condenados por herejía. Asimismo, se desglosan los gastos derivados de los salarios ordinarios, los servicios profesionales externos, las asignaciones asistenciales, los fondos destinados a la guerra de Granada, las mercedes regias y otros conceptos.

PALABRAS Clave: Inquisición; Teruel (España); hacienda; herejía; judeoconversos.

The Financial Structure of the Inquisitorial Court of Teruel: Juan Claver's ADMINISTRATION IN 1487.- In this article, we analyze the Book of the Receptoría of Juan Claver, of the Inquisition court of the Teruel district, related to the fiscal year of 1487, whose balance reflects an accounting balance between income and expenses. First, we study the movable and immovable property auctioned, as well as the income received from eighteen Judeoconvert families, and we write a brief biographical semblance of each one. Likewise, the expenses derived from the ordinary salaries, the external professional services, the assistance allocations, the funds destined to the war of Granada, the royal grants and other concepts.

KEYwORDS: Inquisition; Teruel (Spain); Treasury; Heresy; Judeoconverts.

* Ténganse en cuenta las siguientes abreviaturas: A.C.A. [Archivo de la Corona de Aragón, Barcelona]; A.D.Z. [Archivo Diocesano de Zaragoza]: A.R.V. [Archivo General del Reino de Valencia, Valencia]; A.H.N. [Archivo Histórico Nacional, Madrid]; A.H.P.T. [Archivo Histórico Provincial de Teruel]; A.H.P.Z. [Archivo Histórico de Protocolos de Zaragoza]; A.H.Prov.Z. [Archivo Histórico Provincial de Zaragoza]; y A.C.T. [Archivo de la Comunidad de Aldeas de Teruel, Mosqueruela].

**5877jma@comb.cat

***mamotis@usj.es

Copyright: (C) 2020 CSIC. Este es un artículo de acceso abierto distribuido bajo los términos de la licencia de uso y distribución Creative Commons Reconocimiento $4.0 \mathrm{In}$ ternacional (CC BY 4.0). 


\section{INTRODUCCIÓN}

Uno de los aspectos menos estudiados de la Inquisición en Aragón, en su período fundacional -no así en otras circunscripciones de la Corona como Valencia ${ }^{1}$-, se refiere a la tesorería del tribunal y a la administración de los bienes embargados, que racionaliza la gestión realizada por los magistrados en las distintas sedes, cuya normalización y unificación -a través de textos normativos como las Instrucciones ${ }^{2}$ - será más tardía ${ }^{3}$.

El tribunal de Teruel en este terreno adolece de notables carencias ${ }^{4}$. Salvo un estudio de R. Ferrer, referido al segundo Libro de Receptoría de Juan Claver del año 1488, apenas se ha avanzado ${ }^{5}$. De este modo, estudiamos en profundidad el primer Libro de Receptoría del referido titular, relativo al ejercicio fiscal 1487 -desde el 13 de noviembre de 1486 al 31 de diciembre de 1487-, año en el que actúa como inquisidor Martín Navarro, trasladado con posterioridad a Cala-

${ }^{1}$ Bernardo Tomás Botella, «En los orígenes de la hacienda inquisitorial valenciana: la inspección de las cuentas del receptor Joan Ram Escrivà (1482-1487)», en En el primer siglo de la Inquisición Española, coord. José María Cruselles Gómez (València: Universitat de València, 2013) págs. 251-272, y José María CRuselles GómeZ, «La primera contabilidad inquisitorial. El fondo del Archivo del Reino de Valencia (1482-1527)», en En el primer siglo de la Inquisición Española, coord. José María Cruselles Gómez (València: Universitat de València, 2013) págs. 221-250. Sin olvidar los estudios pioneros de Ricardo García CárCEL, «Las rentas de la Inquisición en Valencia durante el siglo XVI», Anuario de Historia de la Universidad de Granada 2-3 (1975-76) págs. 57-68.

2 Juan Carlos Domínguez Nafría, «Las Instrucciones como fuente del Derecho inquisitorial», en Intolerancia e Inquisición: Actas del Congreso Internacional de Intolerancia e Inquisición, coord. José Antonio Escudero (Madrid: Sociedad Estatal de Conmemoraciones Culturales, 2006) vol. 1 págs. 455-493: 464-475.

3 José Martínez Millán, La Inquisición española (Madrid: Alianza Editorial, 2009) pág. 240.

${ }^{4}$ Jaime Contreras y Jean Pierre Dedieu, «Geografía de la Inquisición española: la formación de los distritos, 1470-1820», Hispania 40 (1980) págs. 37-93: 52.

5 Ramón Ferrer Navarro, «Aspectos económicos de la inquisición turolense a fines del siglo XV», Ligarzas 7 (1975) págs. 275-302 y «Notas sobre la actuación económica de la Inquisición en el Reino de Mallorca a finales del siglo Xv (1489-1490)», Mayurqa 12 (1974) págs. 167-182. 
tayud, cuyas funciones se extenderán de modo interino a la diócesis de Segorbe-Albarracín ${ }^{6}$.

\section{RECEPTORÍA}

El titular de los recursos financieros es designado por el monarca y su gestión queda supeditada al control del Real Patrimonio ${ }^{7}$, donde la figura del maestre racional es nuclear ${ }^{8}$, pues no adquiere plena autonomía hasta mediados del siglo XVI. Fernando II propugna el control del organismo, la libre disposición de sus ingresos y una burocracia ágil ${ }^{9}$.

Su estructura precisa de medios personales que garanticen su gestión, ejecutividad y viabilidad, ya que se pretende que logre su autonomía financiera ${ }^{10}$. El receptor, en gran medida, es un funcionario externo al órgano inquisitorial -si bien los gastos ordinarios debe aprobarlos el magistrado («por mandamiento del inquisidor») ${ }^{11}$-, cuya importancia en el engranaje institucional se refleja en su salario, equiparado al de los jueces ${ }^{12}$.

Criado o ujier al cuidado de la armería del rey -ulteriormente embajador de los Reyes Católicos en Nápoles y Milán al inicio de las guerras de

${ }^{6}$ Cruselles Gómez, «La primera contabilidad inquisitorial», pág. 226.

7 Pilar Huerga Criado, «El inquisidor general fray Tomás de Torquemada. Una inquisición nueva», en Inquisición española. Nuevas aproximaciones, ed. Jaime ConTRERAS CONTRERAS (Madrid: Ariel, 1987) págs. 43-52: 43.

${ }^{8}$ Creado ex novo en el reinado de Alfonso el Magnánimo, siendo la primera mención explícita del 21 de marzo de 1420; $c f$. Beatriz Canellas Anoz, «Del oficio de maestre racional de la Cort en el Reino de Aragón (1420-1458)», Aragón en la Edad Media 16 (2000) págs. 145-162: 146-148.

9 Pilar Huerga Criado, «La Hacienda de la Inquisición aragonesa durante el reinado de Fernando el Católico», Revista de Historia Jerónimo Zurita 63-64 (1991) págs. 51-72: 51.

10 Bernardo José López Belinchón, «La hacienda del Santo Oficio», en L'Inquisition espagnole et la construction de la monarchie confessionnelle (1478-1561), coords. Raphaël Carrasco y Michel Boeglin (Paris: Ellipses, 2002) págs. 165-176: 165.

11 Vr. gr. A.R.V., Maestre Racional, reg. 8322, fols. 45r-v y 47v-50r.

12 Cf. Jordi Ventura i Subirats, «Contribució a l'estudi dels salaris a la Inquisició valenciana», Cuadernos de Historia Económica de Cataluña 1 (1968-69) págs. 185-189. 
Italia ${ }^{13}$, sus servicios fueron muy apreciados, recibiendo su nombramiento mediante provisión expedida en Salamanca, el 13 de noviembre de $1486^{14}$. Se le faculta para que aprehenda, inventaríe y secuestre los bienes muebles, raíces y demás efectos de los procesados («bienes muebles y raices y por si movientes»), una vez adscritos al fisco regio ${ }^{15}$. En cuando a su ejecución se inclina por la subasta en «publico encant» del mobiliario ${ }^{16}$, mientras que el patrimonio inmueble, solo si no hay otra opción, es arrendado de forma provisional. Asimismo, está facultado para percibir rentas y obligaciones, emitiendo los recibos que avalen dichas operaciones.

Días después se expiden dos nuevas provisiones, ampliando su gestión a la compraventa de todo tipo de bienes y enseres. Advertían que esos bienes podían ser onerosos por las cargas que mantenían sus dueños, y la necesidad de liquidez. En la nómina se incluyen «casas, viñas, campos, olivares, huertos, posesiones, heredades e otros cualesquier bienes, derechos, acciones y cosas de cualesquier especie que fueren y por cualquier nombre nombrados». Se exceptúan los censales, deudos y treudos (alquileres) derivados de aquellos ${ }^{17}$.

Se le asigna un salario de 4.000 sueldos, que computa desde que comienza a ejercer, luego de jurar su cargo («principiando del dia que començara a regir e exercer aquel en la dicha ciudat de Teruel, e fara el iuramento de bien y lealmente haverse en aquel») ${ }^{18}$. El hecho de no hacerlo de inmediato generará discrepancias en la peritación de las cuentas efectuada por los auditores Juan Riba y Bernat Dassió -vinculados años antes con las instituciones forales y municipales de la ciudad y el

13 Álvaro Fernández de CóRdova, «El "Rey Católico" de las primeras guerras de Italia. Imagen de Fernando II de Aragón y V de Castilla entre la expectación profética y la tensión internacional (1493-1499)», Medievalismo 25 (2015) págs. 197-232: 204.

14 Ferrer Navarro, «Aspectos económicos de la Inquisición», págs. 295-297.

15 En las Instrucciones de 1484 se pretende frenar los excesos cometidos por los inquisidores en Andalucía, que se negaban a aplicar los beneficios del Edicto de Gracia [Instrucciones de Sevilla de 1484, n. ${ }^{\circ} 13$ y 23-24]. Estas disposiciones no se cumplieron. Miguel JimÉNEZ Monteserín, Introducción a la Inquisición Española. Documentos básicos para el estudio del Santo Oficio (Madrid: Editora Nacional, 1980) pág. 163.

16 A.R.V., Maestre Racional, reg. 8322, fols. 15r, 20r, 23r y 29r.

17 A.R.V., Maestre Racional, reg. 8322, fols. 3r-4r.

18 A.R.V., Maestre Racional, reg. 8322, fols. 6v-7r. 
reino de Valencia ${ }^{19}$, ya que se asigna su retribución desde el 13 de noviembre, a su llegada a la ciudad, no habiendo prestado juramento hasta el 6 de diciembre ante el inquisidor, en presencia de su predecesor, el escudero Alonso de Mesa ${ }^{20}$. Intervienen como testigos los notarios Alfonso Daça y Luis Martínez Cano, expidiendo la escritura el fedatario del tribunal Juan Pérez ${ }^{21}$.

Su jurisdicción se acrecienta el 8 de enero, tras el declive del tribunal -las principales incautaciones se habían producido en sus primeros años de implantación-, al incorporar los obispados de Segorbe y Albarracín ${ }^{22}$. En compensación asume la administración del obispado de Valencia, atribuida el 31 de marzo $^{23}$, estableciendo unos emolumentos de 2.500 sueldos por su gestión en Teruel, además de 4.500 sueldos por la titularidad de Valencia ${ }^{24}$, de modo que sus ingresos ascenderán a 7.000 suel$\operatorname{dos} 25$.

Sus nuevas responsabilidades le obligan a viajar, delegando en terceros, que no llegan a ostentar el rango de lugartenientes, como es el caso del mercader de la ciudad Lucas Gregorio, que abona 68 sueldos a un correo enviado a Salamanca con una encomienda a la Corte Real ${ }^{26}$. Asimismo, se acredita un pago de 27 sueldos a Juan Rubio para adqui-

19 Cruselles Gómez, «La primera contabilidad inquisitorial», págs. 221-250.

20 En el tribunal de distrito de Monzón, el receptor Gil de Andrada, cuyo nombramiento se expide el 3 de febrero de 1487, no toma posesión hasta el día 22, en que se presentará ante el inquisidor Juan Crespo, a quien entrega la provisión «en paper escripta, e sellada con el sillo de su alteza», procediendo a tomarle juramento; $c f$. A.H.P.Z., Protocolo de Johan Fierro, Zaragoza, 1487, fol. 1r y Miguel Ángel Pallarés, Ápocas de la Receptoría de la Inquisición en la zona nororiental de Aragón (1487-1492) (Monzón: Centro de Estudios de Monzón y Cinca Medio, 1995), doc. 9.

21 A.R.V., Maestre Racional, reg. 8322, fols. 1v y 2v.

${ }^{22}$ A.R.V., Maestre Racional, reg. 8322, fols. 4v-5v y Cruselles Gómez, «La primera contabilidad inquisitorial», pág. 225.

23 A.R.V., Maestre Racional, reg. 12094-4, fol. 39v.

24 Bernardo Tomás Botella, Administración económica del distrito inquisitorial de Valencia: la receptoría de bienes confiscados (1482-1493). Tesis Doctoral, Universidad de Valencia, 2016, José María Cruselles Gómez (dir.), págs. 136-152 y 476-482. Disponible en $<$ http://hdl.handle.net/10550/54057> [Consultado: 23/12/2019].

25 A.R.V., Maestre Racional, reg. 8330-3, fol. 31v.

26 A.R.V., Maestre Racional, reg. 8322, fol. 49r. 
rir papel y el material de escritorio que el tribunal necesita para sus diligencias ${ }^{27}$.

La llevanza contable distingue dos grandes rúbricas: las receptas (ingresos) y las datas (gastos) ${ }^{28}$. Todos los actos están documentados, de modo que, en la mayoría de los asientos, al margen, se consigna que el desembolso se ha realizado en cumplimiento de una cédula suscrita por el inquisidor y el visto bueno del escribano de los secuestros ${ }^{29}$.

\section{INGRESOS (RECEPTAS): PATRIMONIO Y RECURSOS ${ }^{30}$}

Los ingresos se sustancian mediante compraventas, arriendos, ejecución de deudas y percepción de rentas ${ }^{31}$. Respetando su sistemática, desglosamos los ingresos de las familias o «casas» ${ }^{32}$, cuyas haciendas son ejecutadas, incluyendo una breve biografía ${ }^{33}$. Una segunda rúbrica

27 A.R.V., Maestre Racional, reg. 8322, fol. 55v.

${ }^{28}$ La tesis de que la monarquía pretendía enriquecerse expropiando los bienes de los conversos ( $c f$. Norman Rотн, Conversos, Inquisition and the Expulsion of the Jews from Spain [Madison, University of Wisconsin Press, 2002] pág. 222 y César Olivera SERrano, «La Inquisición de los Reyes Católicos», Clío y Crimen: Revista del Centro de Historia del Crimen de Durango 2 [2005] págs. 175-205: 198) ha quedado obsoleta, en especial después de los trabajos clásicos sobre la hacienda inquisitorial de José MARTínez MiLlán, «Estructura de la Hacienda Inquisitorial», en Inquisición española y mentalidad inquisitorial, ed. Ángel Alcalá (Barcelona: Editorial Ariel, 1984) págs. 147-173; «Estructura de la Hacienda de la Inquisición», en Historia de la Inquisición en España y América, dirs. Joaquín Pérez Villanueva y Bartolomé EsCandell Bonet (Madrid: Centro de Estudios Inquisitoriales, 1984) págs. 886-1076 y La Hacienda de la Inquisición (1478-1700) (Madrid: Consejo Superior de Investigaciones Científicas, 1984) págs. 59-82.

29 Salvo intervención directa del monarca no era posible efectuar ningún pago. A.R.V., Maestre Racional, reg. 8322, fol. 51v.

30 A.R.V., Maestre Racional, reg. 8322, fol. 8r.

31 José María Lahoz Finestres y Eugenio Benedicto Gracia, «Una relación de autos de fe celebrados en Aragón de 1485 a 1487», Revista de Historia de la Inquisición 15 (2011) págs. 13-25: 23.

32 Pilar Huerga Criado, «La familia judeoconversa», en Familia, parentesco y linaje: Nuevas perspectivas sobre la sociedad europea, eds. James CASEY y Juan HeRNÁNDEZ Franco (Murcia: Universidad de Murcia, 1997) págs. 141-163: 155.

33 Cf. María del Pilar RÁBADE Obradó, «El origen de los archivos del Santo Oficio: una aproximación al valor histórico de las fuentes inquisitoriales», en El Tratado de 
se refiere a los «deudos comunes» atribuidos a los «condempnados de Teruel».

\subsection{Jaime Martínez de Santángel, mayor}

Primogénito de mosén Jaime Martínez de Santángel, caballero, y Rita Ruiz de Santángel, para contraer matrimonio obtuvo dispensa papal, al igual que sus hijos Jaime y Violante ${ }^{34}$. Nacido en Teruel, vive en la Plaza Mayor, centro neurálgico de la ciudad ${ }^{35}$, siendo relajado al brazo secular el 7 de enero de $1486^{36}$. El ajuar doméstico y bisutería de plata, empeñados por particulares como medio de obtener dinero en momentos de crisis, son subastados, pesando en torno a 7,3 kilos de plata, tasada en 3.267 sueldos 7 dineros. Algunos se venden en Valencia por la ausencia de compradores (véase la tabla 1 del Anexo).

Es obvio que los 11.419 sueldos de los inmuebles -de los que en realidad se ingresan 10.429 sueldos, amén de 42 sueldos por los alquileres de unas casas en la puerta de Zaragoza y en la calle Zaragozadistan de expresar su patrimonio, porque las mejores fincas son adjudicadas después de recaer la sentencia, y en un buen número de ellas se abona solo uno de los plazos pactados con el comprador. Obsérvese, no obstante, que la explotación en Tortajada asciende a 3.500 sueldos, y que dos de sus viviendas, emplazadas cerca de la Puerta de Zara-

Tordesillas y su época. Actas del Congreso Internacional de Historia, coord. Luis Antonio Riвot García (León: Junta de Castilla y León, 1995) vol. 2, págs. 751-759.

${ }^{34} \mathrm{La}$ endogamia constituye una práctica eficaz para reproducir el orden social que garantiza la supervivencia de las señas de identidad culturales, étnicas o religiosas; $c f$. Pilar Huerga Criado, En la Raya de Portugal. Solidaridad y tensiones en la comunidad judeoconversa (Salamanca: Ediciones Universidad de Salamanca, 1994) págs. 67-69.

35 A.H.N., Sección Inquisición, Valencia, leg. 546/1, fols. 28r-33r. Pub. Manuel Sánchez Moya y Jasone Monasterio AsPiri, «Los judaizantes turolenses en el siglo XV», Sefarad 32 (1972) págs. 307-340: 325-332.

36 A.H.N., Sección Inquisición, Valencia, leg. 546/1, fols. 1r y 22r; cf. Fernando LóPez Rajadel, Crónicas de los jueces de Teruel (1176-1532) (Teruel: Instituto de Estudios Turolenses, 1994) págs. 304-305 y Manuel SÁNChez Moya y Miguel Ángel Motis Dolader, «Autos de fe celebrados por el tribunal del Santo Oficio en Teruel (1485-87)», Sefarad 77 (2017) págs. 315-351: 330-333. 
goza ${ }^{37}$, suman 2.000 sueldos. No se evalúa la explotación que posee en la Vega de Orrios, por haber sido donada al capitán Juan Garcés de Marcilla (véase la tabla 2 del Anexo).

Diversifica su capital invirtiendo en censales -un mínimo de 46.200 sueldos- emitidos por las corporaciones municipales, cada vez más endeudadas, lo que le reporta unos réditos de entre $5 \%$ y $6,5 \%$, esto es, una renta de 2.547 sueldos 4 dineros. La insolvencia de algunos titulares acumula impagos de dos o tres anualidades (véase la tabla 3 del Anexo).

Los préstamos responden a cantidades modestas, salvo en el caso de la Comunidad de aldeas o el Comendador de Villel, que obedecen a créditos financieros ${ }^{38}$. Los ingresos ascienden a 10.637 sueldos 10 dineros, de un total de 11.592 sueldos (véase la tabla 4 del Anexo).

La cesión del ganado se realiza a través de contratos parciarios ${ }^{39}$, donde el pastor, un moro «medianero» de Orrios, adquiere las reses por 100 sueldos. En el caso de Bartolomé Abad, vecino de Tortajada, explota la finca a medias, entregando 35 fanegas de trigo, 2 de ordio y 18 de espelta, eximiéndole de 4 fanegas de espelta y 2 de ordio destinados a la siembra ${ }^{40}$.

37 El eje viario principal de la ciudad nace en la puerta de Zaragoza, continuando por la calle del Tozal, plaza Mayor o del Mercado y calle del Salvador, desembocando en la puerta de Guadalaviar-San Salvador; $c f$. Miguel SAncho Mir, Agustín Hernández AJA y Jorge Llopis Verdú, «Hacia una nueva concepción del espacio público en el Teruel de la Edad Moderna: Desde el s. XVI hasta el inicio del s. XIX», ACE: Architecture, City and Environment 35 (2017) págs. 191-212: 192.

${ }^{38}$ La vinculación que tanto él como su padre mantienen con las aldeas, le permite percibir en 1460 una suma de 333 sueldos 4 dineros por los trabajos realizados. A.C.T. Sección Hacienda, doc. 2981. Pub. Francisco Javier Aguirre GonzÁlez, (dir.), Catálogo del Archivo de la Comunidad de Teruel (Mosqueruela) (Teruel: Instituto de Estudios Turolenses, 2005) pág. 1004.

39 Miguel Ángel Motis Dolader, «Régimen jurídico de los contratos pecuarios suscritos en Jaca durante el siglo Xv», en $X V$ Congreso de Historia de la Corona de Aragón (Zaragoza, Gobierno de Aragón, 1994) págs. 327-340 y Juan Manuel Berges SÁnchez, Actividad y estructuras pecuarias en la Comunidad de Albarracín (12841516), (Tramacastilla, Teruel: Centro de Estudios de la Comarca de Albarracín, 2009) págs. 654-656.

40 A.R.V., Maestre Racional, reg. 8322, fols. $11 \mathrm{v}$ y $12 \mathrm{v}$. 


\subsection{Casa de Juan Ruiz ${ }^{41}$, el Generalero ${ }^{42}$}

Casado con Donosa Ruiz - cuya efigie es incinerada el 30 de agosto de $1485^{43}$-, engendra al menos tres hijos, Pedro, Gonzalo, jurista, y Rodrigo Ruiz, presbítero, así como tres hijas, una de ellas maridada con Berenguer Ram ${ }^{44}$. Tiene un espíritu de linaje arraigado ${ }^{45}$, residiendo en la cuesta de San Pedro ${ }^{46}$.

Notorio judaizante ${ }^{47}$, su cadáver es incinerado el 17 de mayo de $1486^{48}$. Ello priva a sus descendientes varones, hasta segundo grado, y en primer grado por la línea femenina, «de toda sucession de bienes de los dichos sus padres e madres ${ }^{49}$.

En el primer asiento se señala el molino de La Torre, por el que puja 5.600 sueldos Bartolomé Maicas, vecino de La Puebla de Valverde. Entre tanto es arrendado a Pedro Mateo, molinero de la ciudad, a razón

41 A.R.V., Maestre Racional, reg. 8322, fol. 15r-v.

42 SÁnchez Moya y Monasterio, «Los judaizantes turolenses en el siglo XV», Sefarad 33 (1973) págs. 111-143: 99-100.

43 A.H.N., Sección Inquisición, Valencia, leg. 544/7, fols. 59r-63v, y SÁNCHEZ MoYa y Motis Dolader, «Autos de fe celebrados por el tribunal del Santo Oficio en Teruel (1485-87)», págs. 327-329.

44 Se pagará en «Carnes moliendas» de 1488 .

45 El término linaje aplicado a los grupos sociales urbanos a veces alude a agrupaciones más amplias sin vínculos de sangre. Máximo Diago Hernando, «Estructuras familiares de la nobleza urbana en la Castilla bajomedieval: los doce linajes de Soria», Studia Historica. Historia Medieval 10 (1992) págs. 47-71: 48.

46 A.H.N., Sección Inquisición, Valencia, leg. 543/7, fol. 21r. Allí se concentran hasta 27 familias de conversos en el primer tercio del siglo. A.H.P.T., Libro del Compartimiento de Teruel, 1429, fols. 13v-14r y Miguel Ángel Motis Dolader, «Transformaciones sociales de la aljama judía de Teruel en el reinado de Fernando I de Antequera», en El Compromiso de Caspe (1412). Cambios dinásticos y Constitucionalismo en la Corona de Aragón (Zaragoza: Gobierno de Aragón, 2013) págs. 522-567: 532-534.

47 A.H.N., Sección Inquisición, Valencia, leg. 543/7, fol. 23r y Miguel Ángel Motis DOLADER, «La comunidad judía y conversa de Daroca (Zaragoza) en el siglo Xv: refundación, vida cotidiana y círculos de sociabilidad», Hispania: Revista Española de Historia 76 (2016) págs. 617-643: 636-639.

48 Sánchez Moya y Motis Dolader, «Autos de fe celebrados por el tribunal del Santo Oficio en Teruel (1485-87)», págs. 337-338.

49 A.H.N., Sección Inquisición, Valencia, leg. 543/7, fols. 89r-91v. 
de 75 fanegas de trigo anuales. Durante la vigencia del contrato se genera una renta de 92 fanegas, de las que cuales aporta 73 fanegas, por las que se obtienen 372,5 sueldos. El trigo se vende en partidas de entre $4 \mathrm{y}$ 17 fanegas a particulares, cuyos precios apenas oscilan: 53 fanegas ( 5 sueldos/unidad), 10 fanegas ( 5 sueldos 3 dineros/unidad) y 10 fanegas (5,5 sueldos/unidad).

En sus proximidades posee una parcela, cedida en régimen de aparcería a Juan Calvo, labrador de Teruel, correspondiéndole en esa campaña 20 fanegas, que el receptor vende por 5 sueldos la fanega. Los dos huertos contiguos en el camino del Molino se adjudican a mosén Cabrero, canónigo de Teruel, por 1.100 sueldos. Es obvio que se efectuaron inventarios detallados, como se hizo con ocasión del destierro ${ }^{50}$, ingresándose 288,5 sueldos por los muebles, «segunt que por menudo parece en el inventario de los dichos bienes» ${ }^{51}$. De este modo, los ingresos reportan 5.171 sueldos.

\subsection{Casa de Pedro Ruiz}

Las referencias biográficas proceden de las causas incoadas a su mujer, Beatriz Martínez de Marcilla ${ }^{52}$ y a su tía María del Río, cónyuge de Gonzalo Ruiz, alias del Río ${ }^{53}$, quienes residían en Villalba Alta ${ }^{54}$. Hijo de Donosa y Juan Ruiz, el Generalero, vivió tanto de soltero como una vez contraído matrimonio en casa de sus tíos, observando ritos judaicos ${ }^{55}$.

La cantidad intervenida no es elevada, 2.152 sueldos 10 dineros, pero muestra fortaleza al suscribir un censal con el concejo de Sarrión, cuyo capital es superior al millar de sueldos (véase la tabla 5 del Anexo).

${ }^{50}$ Miguel Ángel Motis Dolader, La expulsión de los judios del reino de Aragón (Zaragoza: Gobierno de Aragón, 1990) vol. 1, págs. 102-133.

51 A.R.V., Maestre Racional, reg. 8322, fol. 15r-v.

52 A.H.N., Sección Inquisición, Valencia, leg. 542/10, fols. 9r-15r.

53 A.H.N., Sección Inquisición, Valencia, legs. 542/10 y 543/9; cf. Manuel SÁNCHEZ MoyA, «Los Marcilla y la Inquisición Turolense», Teruel 33 (1965) págs. 182-183 y «Los judaizantes turolenses en el siglo Xv», Sefarad 33, págs. 140-143.

54 A.H.N., Sección Inquisición, Valencia, leg. 543/9, fol. 22v.

55 A.H.N., Sección Inquisición, Valencia, leg. 543/9, fols. 2r, 6r, 20v-21r, 41r y 47v. 


\subsection{Casa de Francisco Martínez de Rueda, alias Tristán}

Nace en Teruel de padres conversos, bautizados a edad adulta ${ }^{56}$. Su progenitor es enterrado en el monasterio de Jesucristo, compartiendo espacio con su mujer, hermana de Mossé Najarí. Acoge a su hermano Açach Abenrodrich ${ }^{57}$, llegado de Zaragoza ${ }^{58}$, viviendo en la casa paterna de la judería, aunque más tarde se desplaza a sus proximidades. Desde su vivienda se oyen los cánticos de la sinagoga, reprochándoles que el «rabi que agora teneis no tiene buena voz» ${ }^{59}$.

Enviuda en tres ocasiones. Gracia, hija de Berenguer Besant, falleció hacia 1460; Francisca Beltrán, muere hacia 1470; y Leonor Besant, es enterrada en 1477. Su primogénito Francisco procede de su primer enlace; Angelina, Pedro y Juan, jurista, nacieron en el segundo; y fruto del último consorcio, alumbran a Luis y Gabriel ${ }^{60}$. Enjuiciado por el inquisidor Çolivera en Cella, el 17 de julio de 1484, es conducido a las cárceles episcopales tras descubrirle «escondido en un entresuelo o falsa cubierta muy secura» ${ }^{61}$, procediéndose a su relajación al brazo secular en enero de 1486.

Sus intereses laneros son relevantes, como avala una sentencia emitida por el inquisidor y micer Jaime Mora, donde se condena a Miguel Pérez Arnal, vecino de Teruel, a pagar por esta materia prima 2.520 sueldos. Asimismo, un vecino de Visiedo le adeuda 19 fanegas de trigo que totalizan 98 sueldos 2 dineros. Sin embargo, el principal apunte contable se refiere a 7.000 sueldos de renta sobre la ciudad de Teruel de un censal que había suscrito en origen el Canciller de Navarra ${ }^{62}$.

\footnotetext{
56 Sánchez Moya y Monasterio, «Los judaizantes turolenses en el siglo XV», Sefarad 32, págs. 307-312.

57 A.D.Z., Registro de Actos Comunes y de Órdenes, 1423, fol. 32r-v y 1437, fols. $39 \mathrm{v}-40 \mathrm{r}$.

58 A.H.N., Sección Inquisición, Valencia, leg. 542/9, fol. 62v.

59 A.H.N., Sección Inquisición, Valencia, leg. 542/9, fols. 36v-37r, 52v-55v y 62r.

60 A.H.N., Sección Inquisición, Valencia, leg. 542/9, fols. 36v, 40v y 63r-64r.

61 A.H.N., Sección Inquisición, Valencia, leg. 542/9, fols. 32v-33r.

62 A.R.V., Maestre Racional, reg. 8322, fol. 17r.
} 


\subsection{Casa de Gil Ruiz ${ }^{63}$, el Dentudo}

Hermano de Gonzalo Ruiz, mayor ${ }^{64}$, contrajo matrimonio con Violante, hija de Jaime Santángel, mayor, precisando dispensa papal, siendo su progenitor Gil Ruiz, mayor, heredero de Mossé Najarí ${ }^{65}$. Posee un fuerte carácter, a veces colérico, pues amenazó con un cuchillo al nuncio del inquisidor en la Plaza Mayor ${ }^{66}$. En su condición de mercader viajaba con frecuencia, siendo acompañado por un asistente judío que se ocupaba, entre otras cosas, de degollar los animales que comía, lo que provocó que fuera excomulgado ${ }^{67}$.

El proceso se incoa el 11 de octubre de 1484, retomándose el 25 de marzo de 1485, cuando se establece el tribunal en la ciudad, logrando huir con nocturnidad, gracias a la protección de su pariente García Garcés de Marcilla ${ }^{68}$. El matrimonio es relajado en efigie el 30 de agosto de ese año ${ }^{69}$ (véase la tabla 6 del Anexo).

Los bienes son heterogéneos, aunque por su entidad -1.875 sueldos 2 dineros, de los que ingresan 1.629 sueldos 2 dineros- parte de su patrimonio ha sido ya enajenado, pues solo se consigna el resto de un pajar en el arrabal de Teruel, algunos contratos inespecíficos, dos anualidades de un censo sobre el concejo de Mezquita y una modesta cantidad de vino.

${ }^{63}$ SÁnchez Moya y Monasterio, «Los judaizantes turolenses en el siglo XV», Sefarad 33, págs. 124-131.

${ }^{64}$ A.R.V., Maestre Racional, reg. 8322, fol. 18r.

65 A.H.N., Sección Inquisición, Valencia, leg. 546/6, fol. 92r-v.

${ }^{66}$ A.H.N., Sección Inquisición, Valencia, leg. 533/18, fols. 16r-17r. Pub. Miguel Ángel Motis Dolader, «Proceso contra los oficiales del concejo de Teruel por obstrucción al Santo Oficio: "ante se dexarian espedaçar que acoger a los inquisidores, porque vienen contra sus libertades"», Iberia Judaica 6 (2014) págs. 127-152: 132.

67 A.H.N., Sección Inquisición, Valencia, leg. 546/6, fol. 3r.

68 A.H.N., Sección Inquisición, Valencia, leg. 533/14, fol. 27r.

69 A.H.N., Sección Inquisición, Valencia, leg. 546/6, fols. 104r-108v. 


\subsection{Casa de Francés de Puigmija}

Viudo de Francisca Martínez ${ }^{70}$, hija de Rossel Martínez, es procesado el 24 de octubre de 1484 en la iglesia de La Magdalena de Alfambra. Desde hace cuatro décadas reside en la carrera de la Puerta de Zaragoza, cuyas casas están próximas a la sinagoga. Posee unos viñedos que visita los sábados para pagar a sus jornaleros ${ }^{71}$.

Personaje contradictorio, es hombre piadoso que recita constantemente los salmos, contenidos en un libro de Horas, así como un salterio en romance $^{72}$. No siempre es honesto con sus empleados ${ }^{73}$, creando resentimiento («que si los inquisidores vinian, como la ora se sonava, que por ella no cessaria de lo fazer quemar») ${ }^{74}$. Jugador empedernido, gusta apostar a los dados ${ }^{75} \mathrm{y}$ realizar pequeños préstamos sábados y domingos ${ }^{76}$. Su carácter le granjeó numerosos enemigos ${ }^{77}$ (véase la tabla 7 del Anexo).

Ejerció como regidor del concejo en 1482-83, cuando el oficial eclesiástico lanzó anatema a los cristianos que se proveyeran de las carnicerías judías $^{78}$. Es confiado al brazo secular el 7 de enero de

70 Sánchez Moya y Monasterio, «Los judaizantes turolenses en el siglo XV», Sefarad 33, págs. 111-114.

71 A.H.N., Sección Inquisición, Valencia, leg. 542/40, fols. 32r, 53v-54r y 72r-73r.

72 A.H.N., Sección Inquisición, Valencia, leg. 542/40, fols. 15v, 20r-21r y 47v.

73 A María de Tramacastiel le vendió un mulo viejo por 100 sueldos en pago de su soldada, cuando no valía más de 40 sueldos. A.H.N., Sección Inquisición, Valencia, leg. 542/40, fols. $29 \mathrm{r}$ y $74 \mathrm{v}$.

${ }^{74}$ A.H.N., Sección Inquisición, Valencia, leg. 542/40, fols. 29r y 75v.

75 Algunos vecinos que apuestan «a dados, naypes, taulas e otros juegos [...] blasfeman e reniegan de nuestro senyor Dios e de sus santos». A.H.P.T., Sección Concejo, Actos Comunes, 1471-72, fol. 115v.

76 A.H.N., Sección Inquisición, Valencia, leg. 542/40, fols. 19r y 62r.

77 A.H.N., Sección Inquisición, Valencia, leg. 542/40, fols. 70v, 71v-72r y 74v.

78 A.H.N., Sección Inquisición, Valencia, leg. 542/40, fols. 32r y 63r-v. El problema se suscita ya en el año 1453, en que los rectores de la ciudad «atendientes el abuso que se faze por algunas gentes que son christianos en el comprar e comer de las carnes que matan et desfazen los jodios e los moros». La multa de 5 sueldos no debió ser disuasoria, pues unas semanas más tarde duplican la sanción «que como por ley divina e estatutos de la santa madre Iglesia e alias, a todo fiel christiano sia prohibido e vedado comer carnes que desfazen e trasmescan los jodios e moros». La situación persiste, 
$1486^{79}$. El dinero ingresado alcanza 675 sueldos, perteneciendo algunos deudores a la familia Besant. Una viña yerma y unas casas son adquiridas por el monasterio de San Francisco. Trafica con pequeñas partidas de trigo.

\subsection{Casa de Gonzalo Ruiz y su hijo Gil de Gonzalo}

Es nieto de mosén Gil Ruiz Najarí, otrora Samuel Najarí, judío muy relevante de la aljama ${ }^{80}$. Padre de tres hijos ${ }^{81}$, a quienes gusta tener próximos ${ }^{82}$ : Gil de Gonzalo, limosnero del rey ${ }^{83}$-regentan la tiendaalmacén donde se proveen los aldeanos-; Gracia, casada con su primo Jaime Santángel, menor ${ }^{84}$; y Violante, casada con Martín Ruiz ${ }^{85}$. Tanto él como su primogénito son relajados en efigie el 30 de agosto de $1485^{86}$.

$\mathrm{Su}$ hija Gracia aporta en los capítulos matrimoniales dos censales de las Generalidades del Reino, con una renta cada uno de 500 sueldos, uno de los cuales es gestionado por Juan Ruiz, receptor de la Inquisición de Zaragoza ${ }^{87}$. Dos casales, ubicados en la calle del Chopo ${ }^{88}$, son

obligando en 1470 a elevarla a 30 sueldos. A.H.P.T., Sección Concejo, Actos Comunes, 1453-54, fols. 45r-46r y 1470-71, fol. 19v.

79 A.H.N., Sección Inquisición, Valencia, leg. 542/40, fols. 77r-79v.

${ }^{80}$ Los Marcilla emparentaron con los Ruiz, Ram y Santángel con el propósito de consolidar su poder, en unos momentos en que la sociedad estaba polarizada entre este linaje y los Sánchez Muñoz; $c f$. Germán Navarro Espinach, «Muñoces, Marcillas y otras familias dominantes», Anuario de Estudios Medievales 32 (2002) págs. 723-776.

81 Sánchez Moya y Monasterio, «Los judaizantes turolenses en el siglo XV», Sefarad 33, págs. 111-123.

82 A.H.N., Sección Inquisición, Valencia, leg. 544/11, fols. 51r, 61r y 68r.

83 A.H.N., Sección Inquisición, Valencia, leg. 544/11, fol. $1 \mathrm{v}$.

84 A.H.Prov.Z., Sección Inquisición, Zaragoza, leg. 3/5, fol. 48r.

85 A.H.N., Sección Inquisición, Valencia, leg. 543/7, fol. 11r.

86 A.H.N., Sección Inquisición, Valencia, leg. 544/11 y leg. 546/4.

87 A.R.V., Maestre Racional, reg. 8322, fol. 20v.

${ }^{88}$ En una cédula remitida el 3 de agosto de 1487 el soberano establece: «donat poder a mossen Johan Clauer que ensemps ab los reverents inquisidors o inquisidor e no sens aquells puixen de les coses e drets alguns que seran demanats per algunes per- 
retornados a su dueño, el pregonero Juan Gil ${ }^{89}$ (véase la tabla 8 del Anexo).

Afloran deudas contraídas por dos cristianos que las confiesan en el sacramento de la reconciliación («los quales uno le manifesto y dio en confesion»), de ahí que sean los inquisidores o los frailes de San Francisco quienes lo entreguen. Posee cierto número de cabezas de ganado en Bronchales, con parte de las cuales, así lo deducimos de las dos vacas, dos novillos y tres becerros que le corresponden al rey de un contrato a medias -que venderá por 295 sueldos-, suscribió acuerdos de explotación parciaria. Si atendemos a la declaración del encargado del diezmo -se le abonan 10 fanegas de trigo «por el plegar de la primicia ciertos anyos que los tuvo»-, había recaudado 128 fanegas de trigo, 41 fanegas de centeno y 13 fanegas 2 cuartales de cebada, de los cuales el receptor enajena 18 fanegas de trigo, a razón de 5,5 sueldos $^{90}$. Englobando sus fincas rústicas y urbanas -las casas en la calle del Chopo son tasadas en 500 sueldos-, así como el resto de los bienes, sus activos montan 3.566 sueldos 4 dineros, si bien los adeudos son superiores, teniendo en cuenta la producción del diezmo y las prórrogas de algunos pagos.

\subsection{Casa de Berenguer Ram e hijos}

Mercader ${ }^{91}$, sobrino de Mossé Najarí ${ }^{92}$, cuando irrumpe el Santo Oficio se encuentra en plena senectud. De complexión débil y enfermiza («tenia mal de colica passio») ${ }^{93}$, no siempre frena su tempera-

sons sobre les bens confiscats fermarne compromessos e ferne pactes e altres qualsevol avynençes». A.R.V., Maestre Racional, reg. 8322, fol. 4r-v.

89 A.R.V., Maestre Racional, reg. 8322, fol. 20r.

90 A.R.V., Maestre Racional, reg. 8322, fol. $21 \mathrm{v}$.

91 SÁnchez Moya y Monasterio, «Los judaizantes turolenses en el siglo XV», Sefarad 33, págs. 330-337.

92 A.H.N., Sección Inquisición, Valencia, leg. 546/5, fol. 59v.

93 A.H.N., Sección Inquisición, Valencia, leg. 546/5, fols. 48v y 53r. Lo mismo aduce como atenuante Isabel de Santángel, viuda de Ximeno de Crabillas, mercader, ciudadano de Tarazona; $c f$. Miguel Ángel Motis Dolader, «La atenuante de enajenación mental transitoria en la praxis inquisitorial: el tribunal de Tarazona a fines del siglo XV», Aragón en la Edad Media 14-15 (1999) págs. 1125-1150: 1138-1142. 
mento ${ }^{94}$. Su casa, próxima a la judería, es centro de reunión de judaizantes, en especial en la celebración del Quipur ${ }^{95}$. Iniciándose las diligencias el 14 octubre de 1484, su efigie es relajada al brazo secular el 30 de agosto de 1485. La misma suerte correrán sus hijos Fernando y Juan ${ }^{96}$.

El patrimonio inmueble está integrado por fincas residenciales y comerciales en puntos neurálgicos de la ciudad, al punto de que el complejo de una casa con su bodega, junto a la Puerta de Zaragoza, es subastada por 2.560 sueldos, mientras que otra casa con una botiga y un corral alcanza los 3.900 sueldos, cantidades inasequibles para muchos habitantes de la ciudad. El hecho de que el ajuar sea de 147 sueldos 10 dineros permite sospechar que los objetos más valiosos habían sido enajenados (véase la tabla 9 del Anexo).

La familia es titular de unos censales que le permite obtener una renta de 4.960 sueldos 8 dineros, lo que se traduce en un capital de 85.000100.000 sueldos, calculado a una media ponderada del 5-6\%. Se trata de una inversión segura, aunque el tipo de interés es moderado y no especulativo ${ }^{97}$. Su almacén de distribución está muy cotizado, en cuanto que el mercader Juan Ram había aportado 1.200 sueldos en concepto de aval $^{98}$ (véase la tabla 10 del Anexo).

Su hijo Juan Ram arrienda la cosecha de azafrán de la localidad de Munébrega durante «ciertos anyos»-acaso un quinquenio-, del que obtiene 10.077 sueldos. El concejo desembolsa 2.506 sueldos, aplazando el resto en tres entregas, en la Navidad de 1488-9099 (véase la tabla 11 del Anexo).

94 Siendo descubierto mientras escuchaba la oración de la sinagoga, «con muy gran enoxo le dixo que fuese en toda mal ora por a la puta que le havia parido». A.H.N., Sección Inquisición, Valencia, leg. 546/5, fol. 50v.

95 A.H.N., Sección Inquisición, Valencia, leg. 546/5, fol. 66v.

96 A.H.N., Sección Inquisición, Valencia, legs. 543/6 y 543/8.

97 Miguel Ángel Motis Dolader, «Estructura financiera de la comunidad de aldeas de Teruel en el siglo Xv», en Jornadas de estudio sobre los Fueros de Teruel y Albarracin (Teruel: Instituto de Estudios Turolenses, 2000) págs. 109-128.

98 A.R.V., Maestre Racional, reg. 8322, fol. 24r.

99 A.R.V., Maestre Racional, reg. 8322, fols. 24v-25r. 
Se implica en el tráfico de cereales, cuyo precio depende de la calidad: trigo ( 5 sueldos/fanega), centeno y ordio (2,5-3 sueldos/fanega), y espelta ( 2 sueldos/fanega). Comercia con cantidades respetables. Así, 171 fanegas 3 cuartales de trigo, 60 fanegas de centeno, 38 fanegas 3 cuartales de ordio y 16 fanegas 3 cuartales de espelta. El sumatorio de los conceptos contemplados en la tabla indicada -incluyendo los derechos del azafrán y la explotación del almacén de distribución- ascienden a 14.354 sueldos 8 dineros, si bien el receptor ingresa 6.514 sueldos 8 dineros, de modo que recauda un $45,4 \%$ de lo previsto.

\subsection{Casa de Pedro Pomar}

Mercader de profesión y padres judíos, mantiene una relación tormentosa con su hermano Jaime ${ }^{100}$. Según confiesa -el proceso se inicia el 30 de noviembre de $1484^{101}$, , se hizo cristiano a los catorce años en Montalbán «por su propia voluntat» ${ }^{102}$. Los testigos avalan que es buen cristiano, pues asiste con regularidad a misa y milita en la cofradía de San Jorge, lo que no obsta para que tenga enemigos («le menazaron que le farian perder la vida»). Es apresado en Murviedro y ejecutado el 7 de enero de 1486, pese a la defensa de sus abogados Jaime Cabrero, canónigo, y Pedro Alfonso ${ }^{103}$.

Las viviendas, linderas con los herederos de Pedro Besant, soportan un censo anual de 15 sueldos, siendo adquiridas por el tejedor Gaspar García por 250 sueldos. Cantidad modesta si se compara con los 200 sueldos en que se tasa una mula, subastada a Juan de Lamata, que

100 A.H.N., Sección Inquisición, Valencia, leg. 543/4, fol. 25r.

101 SÁnchez Moya y Monasterio, «Los judaizantes turolenses en el siglo XV», Sefarad 33, págs. 345-348.

102 A.H.N., Sección Inquisición, Valencia, leg. 543/4, fol. 25r. La aljama se disuelve en 1415; $c f$. Miguel Ángel Motis Dolader, «Actividad judicial del Santo Oficio en Montalbán (Teruel): ritos de la comunidad conversa a fines de la Edad Media», Stvdivm. Revista de Humanidades 5 (1998) págs. 141-188 y La comunidad judía y conversa en Montalbán (siglos XIV y XV) (Teruel: Comarca de Cuencas Mineras, 2006) págs. 55-60.

103 A.H.N., Sección Inquisición, Valencia, leg. 543/4, fols. 17r, 21v, 54r, 56r, 62v, $72 \mathrm{r}, 75 \mathrm{r}$ y $78 \mathrm{v}-81 \mathrm{r}$. 
abonará en el acto 82 sueldos ${ }^{104}$. El receptor ingresa un total de 332 sueldos.

\subsection{Casa de Luis Martínez de Santángel}

Hidalgo e hijo de Jaime Martínez de Santángel, mayor, y Aldonza Maçana $^{105}$. Casado con Brianda Besant, quien confiaba la lactancia de sus hijas a nodrizas judías, residió en Valencia cinco años, para trasladarse después a Teruel ${ }^{106}$. Se presenta de modo voluntario al Santo Oficio ${ }^{107}$-el proceso se inicia el 11 de octubre de 1484-, acordándose su confinamiento en la ciudad ${ }^{108}$. Era «jodio de coraçon», pues «estar en casa deste mi amo nunca parece, sino que estoy en una juderia». Apreciando que su declaración es insincera, es declarado «erege y apostata» el 27 de marzo de $1486^{109}$ (véase la tabla 12 del Anexo).

Los inmuebles que se subastan son residuales, al tratarse de una casa en la judería, adquirida, como exige la legislación, por un judío, Mossé Maçot ${ }^{110}$; otras casas en Allepuz y un huerto cuyo emplazamiento no se aclara, todo ello estimado en 610 sueldos (véase la tabla 13 del Anexo).

Sus intereses frumentarios ascienden a 262 fanegas de trigo (5-5,5 sueldos), 33 fanegas de ordio (2,5 sueldos), 30 fanegas de cebada ( 2 sueldos) y 75 fanegas de espelta (2-2,2 sueldos). Si a ello sumamos las deudas -englobadas en el crédito de consumo-, este capítulo se evalúa en 2.760 sueldos 6 dineros, de los que restan por pagar 158 sueldos.

104 A.R.V., Maestre Racional, reg. 8322, fol. 28v.

105 A.H.Prov.Z., Sección Inquisición, Zaragoza, leg. 3/5, fol. 37r y A.H.N., Sección Inquisición, Valencia, leg. 544/23, fol. 18r.

106 A.H.N., Sección Inquisición, Valencia, leg. 544/23, fols. 18r, 23r-v, 25v y 26v; cf. SÁnchez Moya y Monasterio, «Los judaizantes turolenses en el siglo xv», Sefarad 32, págs. 332-336.

107 Pilar SÁNChez MoYA, «Carta autógrafa de San Pedro Arbués a los Inquisidores de Teruel», Teruel 17-18 (1957) págs. 341-351: 342-344 y 350-351.

108 A.H.N., Sección Inquisición, Valencia, leg. 544/23, fols. 1r y 16r.

109 A.H.N., Sección Inquisición, Valencia, leg. 544/23, fols. 2r, 28r-v, 65r y 68v.

110 Mossé Maçot es adelantado en 1479. A.H.P.T., Sección Concejo, Actos Comunes, 1479-80, fol. $50 \mathrm{v}$. 


\subsection{Casa de Juan Sánchez Exarch, alias el Royo}

Se inicia su procesamiento el 24 de octubre de $1484^{111}$. Conocedor de la rendición del consejo de Teruel, huye a Daroca, abandonando su domicilio en la carrera de la Puerta de Zaragoza ${ }^{112}$. Hijo de Tolosana de Puigmija, negocia con ganado a pago diferido, aplicando intereses («vende bestias a espera y por mayor precio por razon de la espera») ${ }^{113}$.

Nada pudieron hacer sus abogados, Jaime Cabrero, bachiller, y Pedro Alfonso, jurisconsulto, pues es abocado a la hoguera el 7 de enero de $1487^{114}$. El receptor anota 62 sueldos 8 dineros del mobiliario, «segunt que por el inventario de los dichos bienes por menudo» que, a juzgar por la cuantía, era modesto ${ }^{115}$.

\subsection{Casa de Diego de Toledo}

Natural de Mirabete del Arzobispo, y nacido en torno a 1420, residió en Fababuix con sus padres, Juan y Rita de Toledo. Hacia 1462 se traslada a Teruel, cerca de la judería, cuya vivienda linda con la de Berenguer Ram. En 1483 se empadrona en Daroca, donde reside uno de sus hijos ${ }^{116}$. La almoneda de su ajuar textil alcanza 1.326,5 sueldos, mientras que los préstamos ascienden a 740 sueldos. La recaudación alcanza 2.106 sueldos 6 dineros (véase la tabla 14 del Anexo).

Aficionado a la caza, son notorias sus disputas -con el servicio doméstico o su actitud inflexible en el cobro de sus préstamos-, lo que le

111 Sánchez Moya y Monasterio, «Los judaizantes turolenses en el siglo XV», Sefarad, 33, págs. 126-130.

112 A.H.N., Sección Inquisición, Valencia, leg 544/17, fols. 22v-23r y 27r.

113 A.H.N., Sección Inquisición, Valencia, leg. 544/17, fol. 34v y Antonio FLORIANO Cumbreño, «El tribunal del Santo Oficio en Aragón. Establecimiento de la Inquisición en Teruel», Boletín de la Real Academia de la Historia 86 (1925) págs. 579-581 y 87 (1925) págs. 213-216.

114 A.H.N., Sección Inquisición, Valencia, leg. 544/17, fols. 39r, 55r y 97r-100v.

115 A.R.V., Maestre Racional, reg. 8322, fol. 31v.

116 A.H.N., Sección Inquisición, Valencia, leg. 545/15, fols. 23r y 47r-48r, doc. inserto y leg. 546/3. 
granjea enemistades. Se incoa proceso el 15 de octubre de 1484, siendo condenado el 7 de enero de $1486^{117}$.

\subsection{Casa de Juan de Toledo}

Hijo de Diego de Toledo, contrae nupcias con Violante, hija de Francés de Puigmija, siendo indiciados después de huir de Teruel. Tras reiteradas citaciones, son ejecutados en efigie el 19 de abril de 1486, en la Plaza Mayor ${ }^{118}$. Sus casas en la calle de Domingo Sadornyl, linderas con las de Berenguer Ram, tributaban 10 sueldos a los canónigos de Santa María, siendo adquiridas por 600 sueldos por el monasterio de San Francisco ${ }^{119}$.

\subsection{Casa de Martín Ruiz}

Su difunto padre, Antón Ruiz, fue exhumado y su cadáver incinerado, privándole de toda expectativa sucesoria -le impedía invertir sus bienes en deuda pública emitida por el General de Aragón ${ }^{120}$, al igual que sucedía con sus hermanos Alonso, Antón y Gil. Su mujer, Violante Ruiz, aprovechaba que sus maridos iban a la feria de Daroca para acudir junto a otras conversas a la huerta y observar el ayuno del Quipur («vinian laxas, non pensando en mal ninguno») ${ }^{121}$. Sus muebles son rematados por 365 sueldos 3 dineros ${ }^{122}$.

117 A.H.N., Sección Inquisición, Valencia, leg. 545/15, fols. 18r-v, 43r-44r, 70v, 78r y 79r; $c f$. SÁNChez Moya y Monasterio, «Los judaizantes turolenses en el siglo XV», Sefarad 33, págs. 337-340.

118 A.H.N., Sección Inquisición, Valencia, leg. 542/43, fols. 4v, 10v, 17r-v y leg. 545/16; $c f$. SÁNChez Moya y Monasterio, «Los judaizantes turolenses en el siglo XV», Sefarad 33, págs. 340-342.

119 A.R.V., Maestre Racional, reg. 8322, fol. 32v.

120 A.R.V., Maestre Racional, reg. 12091, fols. 27r y 28r.

121 A.H.N., Sección Inquisición, Valencia, leg. 543/7, fol. 11r y leg. 546/2, fol. 2v.

122 A.R.V., Maestre Racional, reg. 8322, fol. 32v. 


\subsection{Casa de Aldonza Besant}

Casada con el médico micer Pedro Belver - uno de los cinco regidores del concejo que lidera la oposición al Santo Oficio-, nace en el seno de una familia numerosa, pues sus padres, Clara Puigmija y Belenguer Besant, prohíjan diez vástagos ${ }^{123}$. Sus hermanas - Donosa, mujer de Antón Ruiz; Brianda, mujer de Luis de Santángel; y Rita, mujer de Jaime de Santángel, mayor-, siendo todavía doncellas, observan ceremonias judaicas ${ }^{124}$.

Figura la venta de unas casas con su heredad en Concud, gravadas con un censo de 26 sueldos tributados al monasterio de la Merced y a la iglesia de San Miguel, adquiridas por 2.620 sueldos, de cuya cantidad el comprador desembolsa en el acto 1.600 sueldos ${ }^{125}$.

\subsection{Casa de Gracia Ximénez, alias Ram}

Viuda de Fernando Ram, y originaria de Calatayud, fallece a los 85 años ${ }^{126}$. Condenada como «heretica judayzada y apostata» el 7 de enero de 1486, el proceso arrancó el 15 de octubre de 1484, cuando se había fugado («una noche se la levaron de casa en una azemila dos hombres») ${ }^{127}$. El Registro consigna la renta de un censal de la aljama mudéjar de Teruel por 229 sueldos 9 dineros, cuyos miembros abonan 189 sueldos 3 dineros del año $1486^{128}$.

123 SÁnchez Moya y Monasterio, «Los judaizantes turolenses en el siglo XV», Sefarad 33, págs. 138-140.

124 A.H.N., Sección Inquisición, Valencia, leg. 535/14, fols. 33r-35r y leg. 535/13, fols. $34 \mathrm{r}$ y $39 \mathrm{v}$.

125 A.R.V., Maestre Racional, reg. 8322, fol. 33r.

126 A.H.N., Sección Inquisición, Valencia, leg. 5312/24, fols. 46v, 54r y 56r-60v y leg. 546/8, fol. 46v; $c f$. SÁNCHez Moya y MonASTERIO, «Los judaizantes turolenses en el siglo Xv», Sefarad 33, págs. 327-330.

127 A.H.N., Sección Inquisición, Valencia, leg. 546/8, fols. 21v y 50r.

128 A.R.V., Maestre Racional, reg. 8322, fol. 33v. 


\subsection{Casa de Donosa Gracián}

Hija de Luis Gracián, natural de Gerona, y de Donosa Ruiz, vecina de Teruel, tiene ascendencia judía. Nació en Mora de Rubielos y casó en Segorbe con Jaime de Esplugás, asesinado en Teruel en $1464{ }^{129}$. Presenta un perfil ambivalente pues, aunque recita oraciones cristianas -su hermano es capellán-, y asiste a misa, donde comulga, mantiene las ceremonias judaicas que le enseñó su madre ${ }^{130}$. Su vástago regenta una tienda de paños y otras mercaderías escenario de altercados ${ }^{131}$.

Presta dinero a un $8,3 \%$ de interés a algunas judías, «e no lo tiene por pecado pues la Yglesia lo da ad aquel precio» ${ }^{132}$; no en vano, es el rédito que percibe el hospital parroquial de San Juan Bautista ${ }^{133}$. Pese a abjurar, es condenada el 18 de marzo de 1486 a cárcel perpetua y al secuestro de sus bienes bajo el mandato de Alonso de Mesa ${ }^{134}$.

Cuenta con un notable nivel de vida, como muestra el ajuar de plata -estimada en 1,875 kilogramos- la indumentaria -insignia de poder social ${ }^{135}$

129 A.H.N., Sección Inquisición, Valencia, leg. 540/13, fols. 19r-22v y 67r; cf. SÁNChez Moya y Monasterio, «Los judaizantes turolenses en el siglo XV», Sefarad 32, págs. 318-320

130 A.H.N., Sección Inquisición, Valencia, leg. 540/13, fols. 21r y 55r.

$131 V r$. gr. «Hovo grandes differencias e hovieron feas palabras», «Dio huna cuchillada al dicho Acach Maçot», «Descalabro al dicho judío Cara de Toro», etc. A.H.N., Sección Inquisición, Valencia, leg. 540/13, fols. 13r, 20r-v, 43v-44r y $57 \mathrm{v}$. Este último judío protagoniza una brega con un vecino de Torres: «echome mano a los pechos e rasgome la camisa, segunt veyes, e echome mano a la cara, daronme de buenas bofetadas e carrilladas». A.H.P.T., Sección Concejo, Actos Comunes, 1455-56, fol. 39r.

132 A.H.N., Sección Inquisición, Valencia, leg. 540/13, fol. 21v.

133 En general, 8 sueldos 4 dineros por un capital de 100 sueldos; $c f$. Esther Tello HERNÁNDEZ, «La actividad crediticia de un hospital turolense a través de la compra de censales (1482-1517)», Aragón en la Edad Media 26 (2015) págs. 293-320: 307. No obstante, en el ámbito del reino de Valencia el interés fluctúa entre el 7 y el 30\%, dependiendo de las circunstancias; $c f$. Juan Vicente García MARsiLLA, «La formació d'un mercat del crèdit: Origens i difusió del censal en la societat valenciana (segles XIII-XIV)», Butlletí de la Societat Catalana d'Estudis Històrics 12 (2001) págs. 135-144: 139.

134 A.H.N., Sección Inquisición, Valencia, leg. 540/13, fols. 16v y 69r-71v.

135 Juan Vicente García MARSILlA, «La moda no es capricho. Mensajes y funciones del vestido en la Edad Media», Vínculos de Historia 6 (2017) págs. 71-88: 73 y 86 y 
y los complementos, de probable procedencia mudéjar ${ }^{136}$. Son adjudicados solo algunos lotes - por lo común las correas y cinturones tienen una salida más difícil, no así los picheres ${ }^{137}$ y los zafiros de coral-, por los que se obtienen 2.185,5 sueldos. El mobiliario se cifra en 665 sueldos (véase la tabla 15 del Anexo).

Por último, Amador Aliaga restituye 655 sueldos 2 dineros que había tomado de sus enseres. Asimismo, el receptor ingresa 800 sueldos de las rentas de cuatro años (1484-87) de un censal sobre la aljama mudéjar de Gea ${ }^{138}$. El receptor ingresa 3.515 sueldos 8 dineros.

\subsection{Casa de Donosa Ruiz}

Mujer del jurista Antón Ruiz ${ }^{139}$, e hija de Antón Ruiz y Alfonsina, cuyos cadáveres fueron incinerados el 17 de mayo de 1486, vive en un entorno judaico ${ }^{140}$. Se anota un censal de $12.687,5$ sueldos de capital y 787,5 sueldos de renta $(6,2 \%)$, sobre el concejo de Villel ${ }^{141}$, por la dote que aportó al matrimonio ${ }^{142}$. Se ingresan 393 sueldos 9 dineros de las

María Martínez Martínez, «Indumentaria y sociedad medievales (ss. XIII-Xv)», En la España Medieval 26 (2003) págs. 35-59: 45-46 y 49-53.

136 Utilizaban depuradas técnicas en artículos de guarnicionería, aplicando el labrado de oro en distintas prendas de vestir. $c f$. María Martínez Martínez, «Influencias islámicas en la indumentaria medieval española», Estudios sobre Patrimonio, Cultura y Ciencias Medievales 13-14 (2012) págs. 187-222: 219.

137 El picher es común en la cerámica del servicio de mesa, según avalan las excavaciones de la judería; $c f$. Antonio Hernández Pardos, «La cerámica feudal entre mediados de los siglos XIII y XIV, según el repertorio de la plaza de la Judería de Teruel», Arqueología y Territorio medieval 21 (2014) págs. 177-206: 196-197.

138 A.R.V., Maestre Racional, reg. 8322, fols. 34v-35r.

139 A.R.V., Maestre Racional, reg. 8313, fol. 27v y reg. 12091, fol. 30v.

140 A.H.N., Sección Inquisición, Valencia, leg. 543/7, fols. 34r, 36v y 93r.

141 A.R.V., Maestre Racional, reg. 8313, fol. 2r.

142 A.R.V., Maestre Racional, reg. 12091, fol. 30v. En la Valencia bajomedieval las dotes se articulan según los siguientes segmentos: 10-20 libras (artesanado humilde); 20-50 libras (artesanado medio-bajo y pequeños comerciantes); 50-150 libras (artesanado medio-alto, profesiones liberales y comerciantes de entidad); y los potentiores, en el rango superior a las 150 libras (3.000 sueldos); $c f$. José Luis Luz CoMPAÑ y Ana María Gómez Soriano, «Papel de la mujer judía/conversa en la Valencia de finales del s. XIV 
pensiones impagadas, porque el inquisidor había detraído ciertas cantidades para alimentar a su familia, en especial a sus hijas («para dar de comer a la casa de Anton Ruiz, pues todo lo suyo sta tomado a mano nuestra») ${ }^{143}$.

\subsection{Condenados por herejía ${ }^{144}$}

Este capítulo es misceláneo -se incluyen miembros de familias consignadas con anterioridad, que por motivos no aclarados se insertan aquí y no en su rúbrica (Gil de Gonzalo Ruiz, Diego de Toledo, Luis de Santángel, Berenguer Ram, Ferrando de Toledo y Manuel de Puigmija)contemplándose, por lo común, deudas colectivas que agrupan a cierto número de vecinos que deben satisfacerlo «simult et in solum» ${ }^{145}$, en ocasiones en distintas entregas («en diversas jornadas» ${ }^{146}$ ), o personas jurídicas, léase, aljamas o concejos (véase la tabla 16 del Anexo).

Se advierte un elevado índice de impagos, lo que le obliga al receptor a acordar, por lo común, una demora fijada en dos plazos, primando Carnestolendas y el Corpus Christi, mientras que la Navidad se señala en los últimos asientos. Sobre un volumen total de 56.537 sueldos 8 dineros, se abona una suma de 27.283 sueldos 6 dineros. Asimismo, se verifica una apreciable dispersión de intereses que afecta a la Comunidad de aldeas de Teruel y Daroca, lo que demuestra su presencia territorial.

\section{Gastos y expensas (Mesadas)}

Los gastos se desglosan en dos grandes rúbricas: los salarios de ministros y funcionarios del tribunal, tenidos por ordinarios, organizados

e inicios del s. XV», en Historia de la mujer e historia del matrimonio, eds. María Victoria López-CoRdón CoRTezo y Montserrat CARBonell i Esteller (Murcia: Universidad de Murcia, 1997) págs. 87-97: 89-91.

\footnotetext{
143 A.R.V., Maestre Racional, reg. 8322, fol. 35v.

144 En el Registro se agrupan bajo la rúbrica de «los condempnados de Teruel».

145 A.R.V., Maestre Racional, reg. 8322, fols. 37v-38r.

146 A.R.V., Maestre Racional, reg. 8322, fol. 38v.
} 
por rangos; y el resto de las expensas, desglosadas por mensualidades, tenidas por extraordinarias, para atender conceptos diversos, de ahí el término «mesadas», tales como mercedes reales, conquista de Granada, mercancías adquiridas por conversos, servicios profesionales externalizados o abono de derechos a terceros (soldada del servicio doméstico, censales, etc.).

\subsection{Salarios y suplidos}

Uno de los principales obstáculos que hubo de sortear el monarca fueron los propios inquisidores, que se negaban a poner en riesgo el pago de los salarios ${ }^{147}$. No en vano, una de las funciones del receptor consiste en satisfacer los honorarios a inquisidores y ministros.

Los ingresos principales de los oficiales se sustancian en dicho salario, sobre una base de cómputo anual, amén de una asignación a título de «ayuda de costa», que cubría las dietas, actuaciones periciales, etc. dependiendo del rango y el tiempo invertido ${ }^{148}$. Además, existen pagos adicionales, que se incorporarán paulatinamente, derivados de los privilegios del cargo, como la percepción de frutos beneficiales, canonicatos y prebendas ${ }^{149}$.

147 Huerga Criado, «La Hacienda de la Inquisición aragonesa durante el reinado de Fernando el Católico», pág. 59.

148 Como indica su autora, «topamos con una Inquisición ideológicamente aséptica, desprovista de condicionantes religiosos y predispuesta a solucionar desde sus despachos ciertos problemas de carácter social», respecto a sus ministros y oficiales; $c f$. María Jesús Torquemada SÁnchez, «Las funciones tuitivas del Santo Oficio», Anuario de Historia del Derecho Español 67 (1997) págs. 1435-1448: 1435-1436.

149 María Luisa De Miguel GonzáLez, «Características económicas de la Inquisición aragonesa desde 1506-1516», en Inquisición española. Nuevas aproximaciones, ed. Jaime Contreras Contreras (Madrid, Siglo XXI de España Editores, S.A., 1980) págs. 53-75: 70. Los principales problemas entre los Cabildos y el Santo Oficio se suscitaron por motivos económicos, como sucedía en el tribunal de Palma de Mallorca, cuando debían allegarse recursos de las rentas de las canonjías; $c f$. Albert CASSANYes RoIG, «El Cabildo catedralicio de Mallorca y la política de Fernando II el Católico», Espacio, Tiempo y Forma. Historia Medieval 30 (2017) págs. 193-220: 205. 
En una provisión expedida en Salamanca, el 18 de enero de $1487^{150}$, se fija la tabla salarial de los «padres Inquisidores y otros ministros y trabajantes en el dicho Sancto Officio», por importe de 19.000 sueldos, si bien, como comprobamos al cotejar los desembolsos, se despachan solo 16.173 sueldos 11 dineros (véase la tabla 17 del Anexo).

Consta en primer lugar el inquisidor Martín Navarro, vicario de la iglesia parroquial de Cella, advirtiéndose que el titular se reunió con Alonso de Mesa para finiquitar los pagos del ejercicio anterior, que ascendían a 500 sueldos. Sus honorarios se desembolsan en partidas sucesivas. Según los apuntes contables ingresa además 2.320 sueldos 8 dineros ${ }^{151}$.

El estipendio acordado con el alguacil García Rebolledo, desde el 19 de enero hasta la conclusión del ejercicio, se cifra en 3.500 sueldos. De conformidad con las anotaciones realizadas recibe 3.179 sueldos 9 dine$\operatorname{ros}{ }^{152}$.

En el pago de sus emolumentos, el receptor invoca el nombramiento del 19 de noviembre de 1486, con una dotación de 4.000 sueldos, al que se agrega el 31 de marzo de 1487 el tribunal de Valencia ${ }^{153}$. Tras el declive de aquel, la retribución se reduce a 2.500 sueldos en el caso de Teruel, y se fija en 4.500 sueldos el de Valencia. Retiene en su poder 1.455 sueldos 4 dineros del período comprendido entre el 19 de noviembre y el 31 de marzo, así como 1.875 sueldos hasta fines de diciembre, esto es, un total de 3.330 sueldos 4 dineros ${ }^{154}$.

150 A.R.V., Maestre Racional, reg. 8322, fol. 6r-v; pub. Ferrer NAVArro, «Aspectos económicos de la Inquisición turolense a finales siglo xv», págs. 298-299.

151 A.R.V., Maestre Racional, reg. 8322, fol. 62r-v.

152 A.R.V., Maestre Racional, reg. 8322, fol. 63r-v.

153 Los resultados del tribunal de Valencia desde fines del siglo Xv hasta los inicios del siglo XVI, atendiendo a la residencia de los procesados, sobre 3.059 personas, arroja estos datos: Valencia (77,44\%), Teruel (5,23\%), Gandía (3,1\%), Játiva (2,84\%), Tortosa $(2,29 \%)$ y Segorbe $(1,6 \%)$; $c$. Patricia BANEREs, «Prosopografía de los conversos valencianos en el tránsito de los siglos XV-XVI. La problemática de las fuentes inquisitoriales», en En el primer siglo de la Inquisición Española, coord. José María CRUSELLES GómeZ (València: Universitat de València, 2013) págs. 273-294: 291.

154 A.R.V., Maestre Racional, reg. 8322, fol. 67r. El receptor alega «que la intençio del senyor Rey fouch que ell hagues dit salari el dia que fou provehit del dit offici en 
Alonso Daça desempeña la función de escribano real de la receptoría. Contabilizando los ingresos parciales suman 2.650 sueldos 4 dineros, pero se advierte que se le adeuda hasta el 31 de enero un remante de 358 sueldos 8 dineros. En algunos momentos se señalan los vencimientos, que se producen al finalizar enero, abril, mayo, julio, octubre, diciembre, con periodicidad bimensual ${ }^{155}$.

El asesor Jaime Mora recibe un adelanto de 200 sueldos «de sus trebaios», pues el rey no había fijado todavía su retribución («el rey nuestro senyor le mando servir del dicho su officio, e assi de palabra le mando le ayudasse d'algo, ata tanto que por su magestat le fuese consignado su salario») ${ }^{156}$. El notario Domingo Alcacer percibe 500 sueldos, distribuidos en dos partidas, en julio y septiembre ${ }^{157}$ (véase la tabla 18 del Anexo).

Juan Pérez embolsa 2.500 sueldos en condición de notario. Tenía pendiente 843 sueldos hasta el 13 de diciembre, que le serán resarcidos en febrero y julio: 1.354 sueldos (6,5 meses) y 625 sueldos ( 3 meses). Además, señala que los 520 sueldos 10 dineros corresponden al período del 30 de septiembre hasta el 15 de diciembre, «que fueron despedidos los inquisidores de Teruel pora hir a Calatayut» ${ }^{158}$.

El jurista micer Gil Gracián, procurador fiscal, engrosará 150 sueldos, pues «havia de haver y merecia de sus trebaios que passa del dicho su officio», mostrando una corta ejecutoria ${ }^{159}$.

Cuando no se contaba con suficiente numerario se recurrió a préstamos. Así se consigna el 26 de abril de 1487, en que se restituye a Pedro Garcés de Marcilla, habitante en La Puebla de Valverde, un total de 3.000 sueldos que desembolsó para necesidades del tribunal, garantizados con la plata decomisada a Jaime Martínez de Santángel, mayor ${ }^{160}$.

avant, e ques mostra evidentment esser axi e aço per quant als inquisidors ha manat pagar del dia que partia de llurs cases en avant». Ibídem, fol. 79v.

155 A.R.V., Maestre Racional, reg. 8322, fol. 64r-v.

156 A.R.V., Maestre Racional, reg. 8322, fol. 66r.

157 A.R.V., Maestre Racional, reg. 8322, fol. 66v.

158 A.R.V., Maestre Racional, reg. 8322, fol. 65r-v.

159 A.R.V., Maestre Racional, reg. 8322, fol. 67v.

160 A.R.V., Maestre Racional, reg. 8322, fol. 45r. 


\subsection{Asignaciones asistenciales}

Las asignaciones realizadas por parte del rey ${ }^{161} \mathrm{o}$ de los magistrados muestran el estado de postración en que se encuentran algunas mujeres y sus hijos cuando a los progenitores o cónyuges les han embargado sus patrimonios ${ }^{162}$, lo que supone la caída en desgracia del resto de sus miembros ${ }^{163}$. Los casos que se insinúan en el Registro -cuya partida supone 472 sueldos 6 dineros-, reflejan sus carencias, en especial si estaban privados de libertad (véase la tabla 19 del Anexo).

A la viuda Rica de Toledo, el 27 de mayo, se le entrega un cofre de trigo por valor de 29 sueldos, además de 8 sueldos, «para ayuda del sostenimiento de ella y de sus fijos» ${ }^{164}$. Estas gestiones palian sus necesidades en un breve intervalo, lo que obliga a los magistrados, en septiembre, a entregarle otro cahíz de trigo, tasado en 27 sueldos, «para comer a ella y a sus fijos, visto que los bienes della eran confiscados y no tenia de que sustentar su vida», y poco después otros 27,5 sueldos para una provisión de trigo ${ }^{165}$.

A Tolosana, mujer de Alonso de Santángel, se le entregan 100 sueldos para que rehaga su vida en Valencia -donde las interrelaciones son

161 De ello queda constancia en las anotaciones marginales destinadas a los interventores: «Son pressos en compte en virtut de la letra del senyor rey registrada». A.R.V., Maestre Racional, reg. 8322, fol. 54v.

162 Perecidas mercedes son otorgadas por las autoridades eclesiásticas, como el arzobispo de Zaragoza, en favor de los hijos de Leonart de Jaime Eli, «heretico, condempnado e al braço secular relaxado por el crimen de eregia e apostasia e a la camara e fisco de su alteça confiscados», dado que «quedays destituidos de los dichos bienes e soys constituidos en grandissima inopia e necesidat, segunt la condicion vuestra no podeys sustentar la vida humana». A.D.Z., Registro de Actos Comunes y de Órdenes, 1492-97, fols. $9 \mathrm{v}-10 \mathrm{v}$.

163 En el señorío de Cazorla fueron donados a su titular, el cardenal Mendoza. A su muerte los receptores los retornaron al Real Patrimonio, hecho que generó demandas judiciales por parte de los vecinos; $c f$. María del Mar García GuZmán, «Los conversos del señorío de Cazorla a fines de la Edad Media», Estudios sobre patrimonio, cultura y ciencias medievales 13-14 (2012) págs. 109-121: 112-119.

164 A.R.V., Maestre Racional, reg. 8322, fol. 47r.

165 A.R.V., Maestre Racional, reg. 8322, fol. 57r. 
fluidas ${ }^{166}$, en otras palabras, «para que se fuese a Valencia a ganar su vida», probablemente porque allí tenía parientes ${ }^{167}$, como tantos otros conversos, que podrían acogerla y permitirse un modus vivendi ${ }^{168}$.

La delicada situación de Alba, una de las hijas de Jaime Martínez de Santángel, es tal que se consignan dos partidas para atender necesidades básicas de vestido y alimento. La primera, por valor de 121 sueldos, se le entrega al mercader Pedro Díez, por «cierto panyo que dio pora a vestir», mientras que la segunda, estimada en 170 sueldos, se destina para unas camisas y su sustento ${ }^{169}$; de otro modo estaba abocada a la mendicidad.

\subsection{Financiación de la conquista de Granada}

Para el monarca es prioritario atender las urgencias monetarias que demanda la rendición del reino nazarí ${ }^{170}$, no dudando en obtener la mayor cantidad de recursos, incluidos los procedentes de la Inquisición ${ }^{171}$.

166 José Ramón Hinojosa Montalvo, «Actividades comerciales de los judíos en Valencia (1391-1492)», Saitabi: Revista de la Facultat de Geografia i Historia 29 (1979) págs. 21-42: 24; «Los judíos del Reino de Valencia durante el siglo XV», Anales de la Universidad de Alicante: Historia Medieval 3 (1984) págs. 143-182: 169; «Los judíos en el Reino de Valencia: testigos de una historia secular», Anales de la Universidad de Alicante: Historia Medieval 15 (2006-2008) págs. 7-46: 19; «Judíos extranjeros en el reino de Valencia durante la Baja Edad Media», Sefarad 70 (2010) págs. 69-115: 82, «Sederos judíos y conversos en la Valencia medieval», Anales de la Universidad de Alicante: Historia Medieval 18 (2012-2014) págs. 187-224: 203 y «Mudéjares y judíos: minorías en contacto en Aragón y Valencia», en Bajar al Reino: relaciones sociales, económicas y comerciales entre Aragón y Valencia: siglos XIII-XV, coord. Esteban SARASA SÁNCHEZ (Zaragoza: Institución Fernando el Católico, 2017) págs. 223-247.

167 Jesús Villalmanzo Cameno, «La Valencia de Luis de Santángel», en Lluís de Santàngel: Primer Financiero de América, ed. Kathleen E. LeMieux (Valencia: Generalitat Valenciana, 2008) págs. 339-348.

168 A.R.V., Maestre Racional, reg. 8322, fol. 50r.

169 A.R.V., Maestre Racional, reg. 8322 , fols. $50 \mathrm{v}$ y $54 \mathrm{v}$.

170 Miguel Ángel Motis Dolader, «La expulsión de los judíos de la Corona de Aragón y el fin de la tolerancia confesional a fines de la Edad Media», en Poblacions rebutjades, poblacions desplaçades (Lleida: Pagès Editors, 2019) págs. 175-207: 201.

171 Los monarcas, además de acentuar la presión fiscal, exploraron nuevas formas de obtener dinero para proseguir con los esfuerzos bélicos; $c f$. Manuela FernándeZ 
Así, una vez que es operativa, se asientan las transferencias producidas en 1486, en que envía a su repostero, Amador de Aliaga, para que recaude cuanto sea posible de los bienes decomisados ${ }^{172}$. Una nueva solicitud se cursa en 1489, durante el cerco de Baza ${ }^{173}$, «donde pocos dineros se fallavan para tomar», autorizando el envío de 650 florines 11 sueldos 10 dineros valencianos (10.411 sueldos 10 dineros ${ }^{174}$. A lo largo de un quinquenio Juan Claver le entregará un total de 162.400 sueldos. Estos fondos suplen las contribuciones que en otros momentos recaerían sobre las aljamas ${ }^{175}$. Se consignan en este ejercicio fiscal las siguientes cuantías: 23.000 sueldos (17 de marzo), 16.000 sueldos (3 de agosto) y 30.000 sueldos (24 de diciembre) ${ }^{176}$.

\subsection{Servicios profesionales y personal auxiliar}

El tribunal contrata los servicios de diversos profesionales de la ciudad o miembros auxiliares del tribunal para distintos menesteres, cuyo

RODRÍGUEZ, «Guerra y cambios institucionales en el contexto europeo del reinado de los Reyes Católicos», Revista de la Inquisición: intolerancia y derechos humanos 18 (2014) págs. 129-158: 151-152 y Enrique ToRIJA RodríGuEZ, «El subsidio eclesiástico para la guerra de Granada (1482-1492). Aportación, ingresos y gastos en el arzobispado de Toledo», Medievalismo: Boletín de la Sociedad Española de Estudios Medievales 22 (2012) págs. 217-238.

172 A.C.A., Real Cancillería, reg. 3684, fols. 206r-207r y José Ángel SeSma MuÑoz, El establecimiento de la Inquisición en Aragón (1484-86) (=Fuentes Históricas Aragonesas 15 [Zaragoza: Institución Fernando el Católico, 1987]) doc. 197.

173 El cerco de Baza, una de las operaciones más complejas de la guerra, comenzó el 20 de junio de 1489, y no concluyó hasta el 4 de diciembre, gracias a la artillería castellana y su sistema logístico, cobrándose 16.000 bajas. Su pérdida permitió la entrega de Almería a los Reyes Católicos; $c f$. Leandro MarTínez PeÑas y Manuela Fernández RoDríGuEz, La guerra y el nacimiento del Estado Moderno: Consecuencias jurídicas e institucionales de los conflictos bélicos en el reinado de los Reyes Católicos (Valladolid: Asociación Veritas, 2014) págs. 87-98: 96 y Miguel Ángel LAdero QuesadA, «Milicia y economía en la guerra de Granada: el cerco de Baza», Péndulo. Papeles de Bastitania 15 (2014) págs. 45-98.

174 A.R.V., Maestre Racional, reg. 3330-3, fol. 17r.

175 Miguel Ángel Ladero Quesada, «Un préstamo de los judíos de Segovia y Ávila para la Guerra de Granada, en el año 1483», Sefarad 35 (1975) págs. 151-157.

176 A.R.V., Maestre Racional, reg. 8322, fols. 44r, 53v y $61 \mathrm{r}$. 
importe asciende a 5.220 sueldos 3 dineros. Así, la reparación de un molino propiedad de Juan Ruiz, que precisaba restituir unos álabes; el arriendo de un almacén en El Pobo, donde se depositó la cosecha de cebada de las fincas de Luis de Santángel; la estabulación de yeguas; la poda de heredades de Juan y Pedro Ruiz; obras en casas de Jaime Martínez de Santángel, mayor, etc. ${ }^{177}$

Se activan las legaciones para aflorar las deudas («manifestar las deudas que se devian a los condemnados») que los vecinos de la Comunidad de Teruel y Daroca ${ }^{178}$ mantenían con los conversos, área de influencia económica de la ciudad. En ese sentido, se registran diversas comisiones de servicio, como la encomendada a Juan de Heredia, para que investigue deudas ocultas en Daroca, remuneradas con un tercio del capital rescatado ${ }^{179}$.

Los haberes que recibe el notario Francisco Pérez son superiores, dados sus desplazamientos por las aldeas y las dificultades que entrañaba aflorar los débitos, ya que por treinta días ingresa 178 sueldos 8 dineros. Asimismo, las indagaciones se extienden a Valencia. A juzgar por los quince días que permaneció Juan Rubio presentando provisiones, por los que percibe unos 4 sueldos por jornada, el nivel de transacciones era considerable.

Otros se refieren a la escenografía que rodea los Autos de $\mathrm{Fe}^{180}$. En un asiento, fechado el 19 de julio, figura el abono de 24 sueldos a mosén Guarín, clérigo de la ciudad, por la confección de cuatro estatuas «para

177 A.R.V., Maestre Racional, reg. 8322, fol. 47r.

178 La aljama judía local muestra cierta incapacidad de atender el crédito de su mercado interior; $c f$. Miguel Ángel Motis DolADER, «Estructura socio profesional de los judíos de Daroca en la Baja Edad Media», en Actes: Ir. Col·loqui d'Historia dels Jueus a la Corona d'Aragó (Lleida: Institut de Estudis Ilerdenses, 1991) págs. 261-282.

179 A.R.V., Maestre Racional, reg. 8330-3, fol. 32r y reg. 12492-4, fol. 39v. Ocasionalmente, cuando existe relación de consanguinidad, donde el hijo se mantiene en la observancia cristiana, la cuota ascendía a la mitad, al modo en que le sucedió a Juan Martínez de Santángel, en relación con su progenitor. A.R.V., Maestre Racional, reg. 8313 , cautela n. 11 , de 15 de enero de 1488 .

180 Deducimos que corresponden a Beatriz Martínez de Marcilla, el capellán Gil Ruiz de la Cabra, Violante Ruiz y Alfonso Santángel; $c f$. SÁnchez Moya y Motis DoLADER, «Autos de fe celebrados por el tribunal del Santo Oficio en Teruel (1485-87)», págs. 338-339. 
quemar de condenados» ${ }^{181}$-acaso actúa de intermediario-, a razón de 6 sueldos por efigie. Ese día se libran a los fusteros Miguel de Vera y Martín López 16 sueldos por un cadalso para los inquisidores ${ }^{182}$. El 4 de septiembre se paga 12 sueldos a Ferrando Ucaña por cuatro estatuas «que pinto pora quemar» ${ }^{183}$ (véase la tabla 20 del Anexo).

La contratación de correos (Pedro Martínez, Juan Berbete, Juan de Torremocha y Andrés de Valdezebro) se efectúa para diversos fines: entrega de despachos al monarca, por lo común en Salamanca, o al Inquisidor General; correspondencia epistolar con el tribunal de Zaragoza (solicitud de sumarios ${ }^{184}$, dispensación de cartas de comandas); viajes al tribunal de distrito de Calatayud. Cuando no es posible, se delega en los vicarios y presbíteros de las parroquias locales para que entreguen despachos del inquisidor, por lo común cartas citatorias y mandatos. En otras ocasiones se consigna: «sobre cosas fazientes a la Inquisicion» o «cosas necesarias al officio de la Inquisicion».

Amador de Aliaga detendrá a los responsables de la ocultación de bienes a modo de testaferros de los conversos (García Marcilla y Francisco Garcés de Marcilla), y el traslado de testigos para declarar ante el tribunal (Domingo Valero y su hija, vecinos de Mezquita).

\subsection{Soldada del servicio doméstico}

Un cierto nivel de vida comporta la contratación por cuenta ajena de personal externo («moça de servicio», «moça de soldada» o «moça» ${ }^{185}$ ) para las tareas del hogar ${ }^{186}$. Las familias conversas de clase media no tenían elección, porque el mero hecho de carecer de él resultaba com-

181 A.R.V., Maestre Racional, reg. 8322, fol. 51r.

182 A.R.V., Maestre Racional, reg. 8322, fol. 51r.

183 A.R.V., Maestre Racional, reg. 8322, fol. 55v.

184 Jaime Martínez de Santángel, menor, será enjuiciado en Zaragoza, tras recluirlo en la Aljafería, en un largo proceso. A.H.Prov.Z., Sección Inquisición, Zaragoza, leg. 3/5, fol. 88 r-v.

185 A.R.V., Maestre Racional, reg. 8322, fols. 50r, 52r-54r y 57r-58r.

186 Por lo común, la mano de obra aldeana no presenta ningún grado de especialización; cf. José Manuel AbAD AsEnsio, «Obras en el Alcázar y en los Aljibes de 
prometedor; si no había criadas cabía especular que se practicaba el criptojudaísmo y que sus moradores no deseaban ser descubiertos ${ }^{187}$. Alguno de los conversos, tal es el caso del ciudadano Berenguer Ram, mantuvo contratados en su vida adulta a diversas personas, unas en su condición de mercader y otras laborando en su casa ${ }^{188}$.

Estas personas desempeñan una función destacada en el entramado de delación de sus amos ${ }^{189}$, cuya relación es desigual, con cierta tendencia a la incriminación - unas veces de buena fe y otras guiadas por la enemistad-, habida cuenta de que conocen los hábitos cotidianos de sus amos y dueñas ${ }^{190}$.

Diego de Toledo recusa a Olalia, oriunda de Alfambra, «porque la castigaban de algunas malezas que fazia», o Catalina Valero, vecina de Monteagudo, «porque no le acabo de pagar la soldada» ${ }^{191}$. Con Francisco Navarro la malquerencia nacía de que «no le quiso pagar la sol-

Teruel en la segunda mitad del siglo XIV», Aragón en la Edad Media 18 (2004) págs. 337-388: 353.

187 Miguel Ángel Motis Dolader, «Vida cotidiana de los judíos de Teruel en el siglo xv: sintaxis social y geometría punitiva», en Mundos Medievales: Espacios, sociedades y poder (Santander: Universidad de Cantabria, 2012) vol. 2, págs. 1633-1646: 1637-1639.

188 Gonzalo Asensio, habitante en Jabaloyas (5-6 años); Palanciana, mujer de Pascual de Torrezilla, vecino de Teruel (8-9 años); Catalina del Villar, mujer de Pedro Días, vecino de Villel (4 años); María Justa, mujer de Juan López, menor, vecino de Camarena (7 años 8 meses); Catalina Valero, mujer de Pascual Valero, vecino de Castralvo (2,5 años). A.H.N., Sección Inquisición, Valencia, leg. 546/5, fols. 4r, 46v, 50v, 51v y $61 \mathrm{v}$.

189 Juan Antonio BARRio BARRIo, «Los conversos de judío en la ciudad de Xátiva: creencias y prácticas religiosas (1439-1490) a través de la visión del "otro"», Medievalismo: Boletín de la Sociedad Española de Estudios Medievales 23 (2013) págs. 61-99: 64-98 y "'Saben moltes coses contra molts convessos de Xàtiva e de València". Converted Jews in the Kingdom of Valencia: Denunciation and social Betrayal in Late 15th century Xàtiva», Imago temporis. Medium Aevum 10 (2016) págs. 245-265: 251-259.

190 El Manual de inquisidores advierte que el testimonio de la servidumbre debe usarse con circunspección, porque suelen ser maledicentes, si bien constituyen una fuente de información inagotable; $c f$. Ana Benito, «Inquisition and the Creation of the Other», en Marginal Voices. Studies in Converso Literature of Medieval and Golden Age Spain, eds. Amy Aronson-Friedman y Gregory B. Kaplan (Leiden: Brill, 2012) págs. 50-52.

191 A.H.N., Sección Inquisición, Valencia, leg. 545/15, fol. 18v. 
dada», aduciendo que su progenitor la adeudaba cierta cantidad ${ }^{192}$. Su honorabilidad es subrayada por Juana Ramo, vecina de Ababuj, «que estovo moça con el e sallio apalabrada pora esposarse de su casa, e le pago muy bien su soldada, e quedaron muy buenos amigos» ${ }^{193}$.

Catalina, mujer de Bartolomé Izquierdo, vecino de Monteagudo, al servicio del matrimonio durante nueve años, atestigua que comían carne los sábados, así como en el Quipur, en que coincidía con la festividad de san Mateo, «la embiavan a una parte o a otra o por escobas de fuera», absteniéndose de tomar alimento hasta la noche ${ }^{194}$. A ella se suma la declaración de Martín Valero, habitante en Mirabete de la Sierra, que convivió con ellos cinco meses, cuyas costumbres culinarias provenían de tierras de Castilla, de donde eran originarios. Paralelamente, María, mujer de García Fortún, vecino de La Puebla de Valverde, presenció que con motivo de la boda de su hija un judío degolló las aves del ágape nupcial, mientras que «los otros moços christianos [las] pelaban» ${ }^{195}$.

Los inquisidores, fruto de las reclamaciones, abonan los haberes pendientes ${ }^{196}$. Pese a que salvo en una ocasión -indican genéricamente «por lo que havia servido» ${ }^{197}$ - se expresa que la soldada se refiere a una anualidad $^{198}$, atendiendo a la escasa fluctuación de las cantidades, es posible que se trate de los salarios referidos a un período análogo, salvo en supuestos semestrales, aunque es obvio que depende de su cualificación. El desembolso por este concepto es de 1.105 sueldos (véase la tabla 21 del Anexo).

Considerando que, siendo menores de edad, los contratos son firmados por sus progenitores, tutores o curadores, podemos deducir su pro-

192 A.H.N., Sección Inquisición, Valencia, leg. 545/15, fol. 55v.

193 A.H.N., Sección Inquisición, Valencia, leg. 545/15, fol. 58r.

194 A.H.N., Sección Inquisición, Valencia, leg. 545/15, fol. 23r-v.

195 A.H.N., Sección Inquisición, Valencia, leg. 545/15, fols. 24v y $26 \mathrm{r}$.

196 La modalidad de pago depende de los gremios afectados, por ejemplo, los maestres y peones que trabajan en las obras del Alcázar y los aljibes de Teruel reciben sus haberes en metálico por jornada de trabajo, mientras que los mudéjares venidos de Valencia computan por semanas; $c f$. ABAD AsEnsio, «Obras en el Alcázar y en los Aljibes de Teruel en la segunda mitad del siglo XIV», pág. 343.

197 A.R.V., Maestre Racional, reg. 8322, fols. 52r-52v y 54r.

198 A.R.V., Maestre Racional, reg. 8322, fol. 52r. 
cedencia del ámbito rural, como medio de procurarse una futura dote y un mínimo adiestramiento en las tareas del hogar; en el supuesto de no indicarse entendemos que su familia reside en Teruel ${ }^{199}$.

\subsection{Mercancias}

Cuando existen disparidades en las cantidades adeudadas, en aras de abreviar el procedimiento, se acude a la vía arbitral. Ambos acuerdos, consignados el 9 de septiembre, se rubrican con titulares de una botiga $^{200}$. El primero, Sancho Pérez, que regenta un almacén de especias, conviene en recibir 600 sueldos de un total de 1.600 sueldos $(37,5 \%)^{201}$.

Por su parte, el mercader Lucas Gregorio, ciudadano de Teruel, proveedor de «panyos de su botiga» para una amplia clientela de judeoconversos $^{202}$, sobre unas mercancías tasadas en 640 sueldos, obtiene un líquido de 400 sueldos, logrando un acuerdo más ventajoso $(62,5 \%)^{203}$.

\subsection{Censales sobre inmuebles}

Existen inmuebles sobre los que pesan alquileres en favor de eclesiásticos -el poder urbano lo integra el concejo, el rey, el cabildo, los

199 En la Córdoba bajomedieval, una de cada cuatro mozas de servicio tenía esta condición; $c f$. Josefa Leva Cuevas, «El papel de la mujer en la Baja Edad Media. La Dote ¿impulsora del nuevo hogar o yugo para las mujeres?», Ámbitos 19 (2008) págs. 6990: 72 .

200 En el catastro de Florencia de 1427 el vocablo «bottega» alude por extensión al piso inferior de la vivienda dedicada a la actividad manufacturera y comercial; $c f$. Teresa IZqUIERDO ARANDA, «Nuevas consideraciones en torno a la iconografía del obrador de san José carpintero a partir de las evidencias documentales de la carpintería valenciana entre 1400 y 1530», Revista Digital de Iconografía Medieval 9 (2017) págs. 67-84: 79.

201 A.R.V., Maestre Racional, reg. 8322, fol. 56r.

202 Fernando II incrementa las medidas restrictivas respecto al comercio de mudéjares y judíos con el mercado potencial cristiano. A.H.P.T., Sección Concejo, Actos Comunes, 1479, fol. 1r.

203 A.R.V., Maestre Racional, reg. 8322, fol. 56r. 
conventos, los conversos y los judíos ${ }^{204}$-, circunstancia que obliga a sucesivos desembolsos -410 sueldos de unas veinte fincas-, lo que demuestra que no siempre eran titulares del inmueble, y que las instituciones religiosas, en especial la iglesia de San Martín y San Pedro, disponían de cierto patrimonio (véase la tabla 22 del Anexo).

\subsection{Mercedes regias}

El monarca dispone de total discrecionalidad sobre los bienes confiscados, beneficiando a personas próximas a su círculo. Dada la alta estima de que gozaba el receptor Juan Claver recibe una donación de 1.000 florines, «en contemplacion de matrimonio», de los que ingresa 9.600 sueldos ${ }^{205}$. Paralelamente, las resoluciones atienden los problemas de tesorería de otros tribunales, abonándose 1.000 sueldos a Jaime Millán, baile de Castelfabib, en virtud de su salario como escribano del tribunal de Barcelona ${ }^{206}$.

Asimismo, micer Juan Navarro, criado de su casa, percibe 3.145 sueldos, a tenor de una cautela regia consignada por el Maestre Racional. Además, y en favor del difunto Gómez Manrique, procurado por Francisco Guerra, y del prior del monasterio de San Bernardo de Toledo, albaceas testamentarios de Luis Manrique, establece una suma de 200 florines, esto es, 3.200 sueldos. Por último, 80 sueldos son entregados a Brianda de Campos, heredera de Francisco de Campos, sin especificar los motivos 207 .

${ }^{204}$ Alejandro Ríos CONEJERo, «El poder de la oligarquía urbana de Teruel», Aragón en la Edad Media 27 (2016) págs. 271-297: 279.

205 Constan dos partidas por importe de 3.200 sueldos [17 de marzo de 1487] y 6.400 sueldos [7 de enero de 1488]. A.R.V., Maestre Racional, reg. 8322, fols. 59r y $60 \mathrm{v}$.

206 A.R.V., Maestre Racional, reg. 8322, fol. 45r. La economía de esta sede fue muy precaria, y los salarios inferiores; $c f$. Joan BADA I EliAs, «El Tribunal de la Inquisición en Barcelona, ¿un tribunal peculiar?», Revista de la Inquisición 2 (1992) págs. 109-120: 115-116. En contrapartida, la Inquisición de Teruel necesitó de una provisión de fondos efectuada por Joan Ram Escrivà, receptor de Valencia, el 5 de mayo de 1484, por importe de 3.000 sueldos. A.R.V., Maestre Racional, 8323-2, fol. 39r.

207 A.R.V., Maestre Racional, reg. 8322, fols. 51r y 60r. 


\section{Auditoría INTERnA}

Tanto las partidas de ingresos como de gastos son intervenidas ${ }^{208}$. En cuanto a los gastos, antes de traducir su equivalente en sueldos jaqueses, se desglosan por monedas: 90.907 sueldos; 3.370 sueldos barceloneses [3.145 sueldos 4 dineros]; 10 fanegas de trigo [55 sueldos]; 1.220 florines [19.520 sueldos]; 7 ducados [154 sueldos] y 1 sueldo castellano [28 sueldos]. Totalizan de este modo 113.449 sueldos 4 dineros. Así, los ingresos ascienden a 113.724 sueldos 2 dineros, de modo que, atendiendo a estas cifras se logra un equilibrio contable, con un leve superávit de 274 sueldos 10 dineros ${ }^{209}$.

Los auditores exigen el inventario de los bienes confiscados y las compraventas realizadas, autenticado por los notarios Alfonso Daça y Luis Martínez Cano, acreditación en el cargo, facturas de los bienes y efectos vendidos, así como todo aquello pendiente de percibir asentado en el Libro de Notamientos. Tras elevar consultas al monarca, Juan Riba, maestre racional de Valencia, y Bernart Dasio, notario ${ }^{210}$, contrastada la documentación presentada y cumplidos los requerimientos sobre las sumas no cobradas y los haberes diferidos, entregan certificación favorable en Valencia, el 25 de enero de $1489^{211}$.

\section{BALANCE Y REFLEXIONES FINALES}

Las siguientes reflexiones se centran en un ejercicio económico de la receptoría de Juan Claver, que adquirirán mayor dimensión cuando culminemos toda su ejecutoria concerniente al período $1487-91^{212}$. No obstante, es un referente válido para trazar unas líneas directrices (véase la tabla 23 del Anexo).

208 CRuSelles Gómez, «La primera contabilidad inquisitorial», págs. 236-237 y Tomás Botella, «En los orígenes de la hacienda inquisitorial valenciana...», págs. 256-257.

209 A.R.V., Maestre Racional, reg. 8322, fols. 68v-70r.

210 Nombramiento efectuado el 15 de enero de 1488. A.R.V., Maestre Racional, reg. 8322, fol. $1 \mathrm{r}$

211 A.R.V., Maestre Racional, reg. 8322, fols. 78r-81r.

212 Sobre las fuentes existentes, $c f$. CRUSELles GómEZ, «La primera contabilidad inquisitorial», pág. 223, nota 4 . 
La fiscalidad concejil distingue tres tramos: la mano mayor (caballería villana, con caballo y un arnés valorado en 200 sueldos); la mediocre (mercaderes, notarios, artistas y otros grupos profesionales) y la menor (menestrales y agricultores) ${ }^{213}$. En parecidos términos los vecinos de las aldeas con un patrimonio superior a 800 sueldos tributan una pecha completa; entre 400 y 800 sueldos (1/4 de pecha); entre 100 y 200 sueldos (1/8 de pecha); estando exentos los que no alcanzan 100 sueldos ${ }^{214}$. En el primer tercio del siglo, los conversos, nacidos de la Disputa de Tortosa, se agrupan en tres segmentos: los que tributan más de 40 sueldos $(35,5 \%)$, los que aportan entre 25 y 40 sueldos $(22,6 \%)$ y los que abonan entre 2,5 y 25 sueldos $(41,9 \%)^{215}$.

Entre los conversos se advierte también una gran diversidad patrimonial, tal y como se observa en la tabla, donde reflejamos la tasación de los bienes y los ingresos efectuados en ese ejercicio económico ${ }^{216}$. La relación de bienes muestra la solidez de algunos linajes -Jaime Martínez de Santángel, Francisco Martínez de Rueda y Berenguer Ram e hijos-, en parte desarticulados por las incautaciones ${ }^{217}$.

213 Antonio Gargallo Moya, El Concejo de Teruel en la Edad Media (1177-1327) (Teruel: Instituto de Estudios Turolenses, 1996) págs. 802-803.

214 Antonio Gargallo Moya, Los orígenes de la Comunidad de Teruel (Teruel: Instituto de Estudios Turolenses, 1984) págs. 54-56, doc. 4 y Motis DOLADER, «Estructura financiera de la comunidad de aldeas de Teruel en el siglo XV», págs. 109-128. Este esquema es similar al adoptado en la Comunidad de Albarracín; $c f$. Eloy Cutanda PÉREZ, La Comunidad de Albarracín en los siglos XVI y XVII (Hacienda, élites y poder) (Tramacastilla, Teruel: Centro de Estudios de la Comarca de Albarracín, 2008) págs. 43-45.

215 Motis Dolader, «Transformaciones sociales de la aljama judía de Teruel...», págs. 252-267.

216 En el inventario de los bienes incautados en la Inquisición de Barbastro se delimita: una oligarquía muy rica; un segmento medio-alto que tiene medios de vida y propiedades cotizadas; una mayoría, que posee una hacienda razonable; una parte vulnerable, que afronta el día a día con dificultad; y los que viven de la caridad; $c f$. Miguel Ángel Motis Dolader, «El linaje de los Santángel de Aragón: mentalidad y estructura socioeconómica», en Lluís de Santàngel: Primer Financiero de América, ed. Kathleen E. LeMieux (Valencia: Consellería de Educación, Investigación, Cultura y Deporte, 2008) págs. 99-143: 139-140.

217 Los inquisidores no pretendían su desaparición física, sino la extirpación de su influencia social mediante su inhabilitación, infamia e inoperancia económica, lo que les condenaba al ostracismo social; $c f$. Motis Dolader, «La expulsión de los judíos de la 
Las familias más relevantes diversifican su patrimonio, viviendas o locales comerciales en las arterias más cotizadas, e invierten tanto en préstamos domésticos y comerciales como financieros, donde la deuda pública (aljamas mudéjares, concejos y Generalidades) les permite percibir ingresos seguros, aunque con intereses no muy elevados $(5-6,5 \%)$. Los ajuares de orfebrería o complementos -Jaime Martínez de Santángel y Donosa Gracián- reflejan su estatus social y un mercado más soterrado como es el del empeño (véase la tabla 24 del Anexo).

La economía de algunos compradores, o el importe de ciertas adquisiciones, explica que el fisco ingrese un $70 \%$ de lo previsto, remitiendo el resto al ejercicio siguiente, puesto que responden a un espectro social amplio, no advirtiéndose una transferencia de capitales hacia la oligarquía ciudadana o la nobleza villana.

Su implantación en el mercado crediticio -la actividad de la aljama judía declina en paralelo con la emergencia de esta nueva microsociedad, lo que creará tensiones ${ }^{218}$, es notable, si bien sus clientes no se centran en la ciudad, sino que se extienden por la Comunidad de aldeas de Teruel y Daroca, de modo que el flujo de capitales, no superior a los 300 sueldos, estimuló la actividad económica. De hecho, el recurso del préstamo impregna todos los sectores de la población, contribuyendo a la cohesión social ${ }^{219}$.

La producción de cereal se mantiene equilibrada -el Almudí ejerce de mecanismo regulador-, a tenor de la tasación de las diversas variedades -trigo ( 1 fanega $=5-5,5$ sueldos), centeno $(1$ fanega $=2,5-3$ sueldos $)$, ordio ( 1 fanega $=2,5-3,3$ sueldos $)$ y cebada ( 1 fanega $=2$ sueldos $)$, que en época de carestía se triplican ${ }^{220}$, llegándose a prohibir en 1474 su co-

Corona de Aragón y el fin de la tolerancia confesional a fines de la Edad Media», pág. 190.

218 Motis Dolader, «La comunidad judía y conversa de Daroca (Zaragoza) en el siglo XV», págs. 636-639.

219 Esther Tello Hernández, «La actividad crediticia de un hospital turolense a través de la compra de censales (1482-1517)», págs. 304-305 y Juan Vicente GARCía MARsilla, «La formació d'un mercat del crèdit: Origens i difusió del censal en la societat valenciana (segles XIII-XIV)», Butlletí de la Societat Catalana d'Estudis Històrics 12 (2001) págs. 135-144: 138.

220 Germán Navarro EsPINACH, «Sociedad y economía medievales», en Historia de la ciudad de Teruel, eds. Montserrat Martínez GonzÁlez y José Manuel Latorre (Teruel: Instituto de Estudios Turolenses, 2014) págs.157-184: 164-165 y Fernando D. 
mercialización e importándose de Zaragoza 1.500 fanegas de trigo ${ }^{221}$. Sus intereses agropecuarios son secundarios, pactándose contratos parciarios.

La política matrimonial anterior a la Inquisición es endogámica, tendiendo a la unión con la prima por parte paterna o materna -aunque se requiera licencia eclesiástica-porque consolida el linaje ${ }^{222}$. En su genética los enlaces muestran cierta movilidad geográfica, con predominio de la virilocalidad, creando relaciones socioeconómicas, reconstruyendo patrimonios o frenando procesos de desestructuración ${ }^{223}$ (véase la tabla 25 del Anexo).

A tenor de los gastos, la discrecionalidad del monarca es notoria, al punto de que casi seis de cada diez sueldos ingresados se destinan a financiar la guerra de Granada. Si englobamos las donaciones regias a terceros, el capítulo de libre disposición se eleva al 75\% de los ingresos. No obstante, el celo del receptor y una política de austeridad, permiten un equilibrio financiero, criterio, acaso, que frenó las apetencias de la Hacienda Real, que no podía generar un déficit que repercutiría a la postre en sus propias cuentas.

Los salarios ordinarios y los servicios profesionales de miembros auxiliares y externos apenas alcanzan el 14,26\%. El resto, amén de amortizaciones de un préstamo para poner en marcha el tribunal $(2,64 \%)$, obedece a expensas generadas por los inmuebles arrendados por los conversos, mercancías impagadas, soldadas del servicio doméstico y manutención de personas caídas en la indigencia, tan apenas un 2,63\%. En suma, la gestión de Juan Claver concluye con un leve superávit de 274 sueldos 10 dineros.

Recibido: 11/11/2019

Aceptado: 27/02/2020

Zulaica Palacios, «Evolución de los precios y salarios aragoneses entre 1300-1430», Aragón en la Edad Media 12 (1995) págs. 123-152: 144-149.

221 A.H.P.T., Sección Concejo, Actos Comunes, 1474, fols. 14v-15r, 16r y 22r.

222 Miguel Ángel Motis Dolader, «Moral sexual y estrategias matrimoniales en el mundo judío y converso durante la Edad Media en la Península Ibérica», en Matrimonio y sexualidad: normas, prácticas y transgresiones en la Edad Media y principios de la Época Moderna, coord. Martine Charageat (Madrid: Casa de Velázquez, 2003) págs. 65-112: 74-79.

223 Huerga Criado, En la Raya de Portugal. Solidaridad y tensiones en la comunidad judeoconversa, pág. 77. 
Anexo

Tabla 1. Artículos de plata procedentes del ajuar doméstico 224

\begin{tabular}{|c|c|c|c|}
\hline Objeto & Ponderación & Ingresos & Adquirente \\
\hline $\begin{array}{l}\text { Cuatro platos de plata } \\
\text { de servicio de mesa }\end{array}$ & 7 marcos 3 cuartos & 815 sj. 10 d. & $\begin{array}{l}\text { Mosén Pujades } \\
\text { [Valencia] }\end{array}$ \\
\hline Un jarro de plata & $\begin{array}{c}15 \text { onzas } 2 \text { cuartos } 2 \text { arienzos } \\
{[1 \text { onza }=15 \mathrm{sj} .8 \mathrm{~d} .]}\end{array}$ & $245 \mathrm{sj}$. & Mosén Campos \\
\hline $\begin{array}{l}\text { Una jarra, tres tazones, } \\
\text { una taza y un salero }\end{array}$ & 78 onzas & $1.000 \mathrm{sj}$ & $\begin{array}{l}\text { Sancho Malo } \\
\text { [Teruel] }\end{array}$ \\
\hline $\begin{array}{l}\text { Dos tazas y dos } \\
\text { escudillas de plata }\end{array}$ & $\begin{array}{c}5 \text { marcos } 1 \text { onza } 2 \text { cuartos } \\
{[1 \text { marco }=110 \mathrm{sj} .6 \mathrm{~d} .]}\end{array}$ & 573 sj. 3 d. & Juan Boil \\
\hline Seis correas & $\begin{array}{l}6 \text { marcos } 6 \text { onzas } 1 \text { cuarto } \\
{[1 \text { onza }=11 \text { sj. } 6 \mathrm{~d} \text {. }]}\end{array}$ & $624 \mathrm{sj}$. & $\begin{array}{l}\text { Lucas Gregorio y } \\
\text { Maestro, canónigo }\end{array}$ \\
\hline $\begin{array}{l}\text { Una cadenilla de plata } \\
\text { dorada y dos piezas de } \\
\text { cordón negro }\end{array}$ & 2 onzas 3 cuartos & {$[\ldots]^{225}$} & \\
\hline Una cucharilla de plata & $\begin{array}{c}2 \text { cuartos } 2 \text { arienzos } \\
{[1 \text { onza }=15 \mathrm{sj} .]}\end{array}$ & $9 \mathrm{sj} .4 \mathrm{~d}$. & Pedro Barberán \\
\hline
\end{tabular}

Tabla 2. Fincas urbanas y explotaciones agrarias 226

\begin{tabular}{|c|c|c|c|c|c|}
\hline Inmueble & Ubicación & Tasación & Ingreso & Adquirente & Localidad \\
\hline Casas* & Puerta de Zaragoza & $280 \mathrm{sj} .^{227}$ & $200 \mathrm{sj}$. & Lorenzo Bernabe & Teruel \\
\hline Casas & PuertadeZaragoza & $1.100 \mathrm{sj}$. & $1.100 \mathrm{sj}$. & $\begin{array}{c}\text { Convento de } \\
\text { S. Francisco }\end{array}$ & Teruel \\
\hline
\end{tabular}

224 A.R.V., Maestre Racional, reg. 8322, fols. 8r-9r. Para la ponderación, ténganse en cuenta las siguientes equivalencias: 1 marco $[233,89$ gramos] $=8$ onzas; 1 onza $=4$ cuartos; 1 cuarto $=4$ arienzos.

225 No se incluye, por tratarse de plata dorada y no de oro, como se había declarado. No en vano, en las aduanas entre Aragón y Valencia se constata que del norte de África llegaban remesas de oro falso o de muy baja calidad, el oripel; cf. Concepción VilLaNUEVA MORTE, «El comercio de joyas y ornamentos registrado en las aduanas del Sur de Aragón en el siglo XV», Aragón en la Edad Media 20 (2008) págs. 829-847: 833.

226 A.R.V., Maestre Racional, reg. 8322, fols. 8v-11r y 12r. Se utiliza un asterisco (*) sobre el inmueble si afronta algún tipo de gravamen. Se aplican dos asteriscos $(* *)$ cuando se trata de una cantidad que restaba por pagar del precio convenido.

227 Abonará los 80 sueldos restantes en Carnestolendas de 1488.

228 Lázaro Romeu, vecino de Teruel, paga un alquiler de 35 sueldos hasta el 4 de septiembre de 1487. 


\begin{tabular}{|c|c|c|c|c|c|}
\hline Inmueble & Ubicación & Tasación & Ingreso & Adquirente & Localidad \\
\hline Casas & $\begin{array}{c}\text { Sobre la Barrera } \\
\text { Alta }\end{array}$ & $630 \mathrm{sj}$. & 200 sj. $^{229}$ & Juan Carroz, sastre & Teruel \\
\hline Casas & Puerta Zaragoza 230 & $900 \mathrm{sj}$. & $900 \mathrm{sj}$. & $\begin{array}{l}\text { Convento de } \mathrm{S} \text {. } \\
\text { Francisco }\end{array}$ & Teruel \\
\hline Casas & $\begin{array}{l}\text { Cerca de la } \\
\text { sinagoga }\end{array}$ & $200 \mathrm{sj}$. & $--{ }^{231}$ & Mosse Maçot & Teruel \\
\hline $\begin{array}{c}\text { Casas } \\
\text { pequeñas }\end{array}$ & Morería & $183 \mathrm{sj}$. & $183 \mathrm{sj}$. & {$[\ldots]$ Larqui, moro } & Teruel \\
\hline $\begin{array}{l}\text { Casas y } \\
\text { heredad }\end{array}$ & $\begin{array}{l}\text { Vega de Orrios } \\
\text { (Teruel) }\end{array}$ & {$[\ldots]$} & $--{ }^{232}$ & $\begin{array}{c}\text { Juan Garcés de } \\
\text { Marcilla }\end{array}$ & Teruel \\
\hline Huerto & Mulatilla & $315 \mathrm{sj}$. & $--2^{233}$ & Francisco Pérez & Teruel \\
\hline $\begin{array}{l}\text { Casas y } \\
\text { heredad }\end{array}$ & Tortajada & $3.500 \mathrm{sj}$ & $3.500 \mathrm{sj}$. & $\begin{array}{c}\text { Juan Garcés de } \\
\text { Marcilla }\end{array}$ & Teruel \\
\hline Casas & Puebla de Valverde & $800 \mathrm{sj}$. & $800 \mathrm{sj}$. & Juan de Galve & La Puebla \\
\hline Casas & {$[\ldots]$} & 140 sj. $^{* * *}$ & $140 \mathrm{sj}$. & [Antón Boix] & Teruel \\
\hline Casas & {$[\ldots]$} & $250 \mathrm{sj.}^{* *}$ & $250 \mathrm{sj}$. & $\begin{array}{c}\text { Juan de Tolosa, } \\
\text { clérigo }\end{array}$ & Teruel \\
\hline $\begin{array}{l}\text { Casas y } \\
\text { heredad }\end{array}$ & {$[\ldots]$} & $345 \mathrm{sj.}^{* *}$ & $300 \mathrm{sj}^{234}$ & Juan de Villalba & Villalba \\
\hline Casas & {$[\ldots]$} & $1.300 \mathrm{sj} .^{* *}$ & $1.300 \mathrm{sj}$. & Domingo Darocano & Teruel \\
\hline Casas & {$[\ldots]$} & $380 \mathrm{sj.}^{* *}$ & $380 \mathrm{sj}$. & $\begin{array}{c}\text { Juan Garcés, } \\
\text { pellejero }\end{array}$ & Teruel \\
\hline Huerto & {$[\ldots]$} & $550 \mathrm{sj}^{* * *}$ & $550 \mathrm{sj}$. & $\begin{array}{l}\text { Mujer de Juan de } \\
\text { Santángel }\end{array}$ & Teruel \\
\hline Heredad & {$[\ldots]$} & $250 \mathrm{sj}^{* * *}$ & $250 \mathrm{sj}$. & Juan Bellido & $\begin{array}{c}\text { Formiche } \\
\text { Bajo }\end{array}$ \\
\hline Azafranal & {$[\ldots]$} & 296 sj. $^{* *}$ & $296 \mathrm{sj}$. & Pedro de Miede & Teruel \\
\hline
\end{tabular}

229 Abonará los 430 sueldos restantes en Carnestolendas y san Juan de 1488.

230 Juan Martín, soguero, abona 7 sueldos de alquiler («loguero») por un cuatrimestre.

231 Se liquidará en Carnestolendas de 1488.

232 Donación real.

233 Se pagará en «Carnes moliendas» de 1488.

234 Finiquitará los 45 sueldos restantes en Carnestolendas de 1488. 
Tabla 3. Censales suscritos por aljamas mudéjares y concejos cristianos ${ }^{235}$

\begin{tabular}{|c|c|c|c|c|c|}
\hline Deudor & Localidad & Capital & Renta & Interés & Ingreso \\
\hline Aljama mudéjar & Teruel & {$[\ldots]$} & $500 \mathrm{sj}$. & {$[\ldots]$} & $500 \mathrm{sj}$. \\
\hline Concejo & Teruel & $8.000 \mathrm{sj}$. & $400 \mathrm{sj}$. & $5 \%$ & $1.200 \mathrm{sj}$. \\
\hline Concejo & Teruel & $15.000 \mathrm{sj}$. & $937 \mathrm{sj} .4 \mathrm{~d}$. & $6,25 \%$ & $2.812 \mathrm{sj}$. \\
\hline Concejo & Teruel & $9.000 \mathrm{sj}$. & $500 \mathrm{sj}$. & $5,5 \%$ & $1.500 \mathrm{sj}$. \\
\hline Concejo & Fababuix & {$[\ldots]$} & $210 \mathrm{sj}$. & {$[\ldots]$} & $420 \mathrm{sj}$. \\
\hline
\end{tabular}

Tabla 4. Préstamos y deudas de la ciudad y comunidad de Teruel ${ }^{236}$

\begin{tabular}{|c|c|c|c|}
\hline Deudor & Localidad & Ingresos & Observaciones \\
\hline Pascual Domínguez & Aldehuela & 94 sj. 10 d. & \\
\hline Martín del Forno & Caudé & $43 \mathrm{sj}$. & Resto de mayor cuantía \\
\hline Pascual Orero & Cubla & $115 \mathrm{sj}$. & \\
\hline Ferrán Pérez & Caudé & 422 sj. & \\
\hline Pascual de Orrios & Teruel & $130 \mathrm{sj}$. & \\
\hline Sancho de Obón & Teruel & $210 \mathrm{sj}$. & \\
\hline Antón de Vallecroche & {$[\ldots]$} & $800 \mathrm{sj}$. & $\begin{array}{c}400 \text { sj. restantes en } \\
\text { Domingo de } \\
\text { Resurrección }\end{array}$ \\
\hline Juan Romeu & Alfambra & $500 \mathrm{sj}$. & $\begin{array}{c}500 \text { sj. restantes en } \\
\text { S. Bartolomé/88 }\end{array}$ \\
\hline $\begin{array}{l}\text { Pedro Villarroya, } \\
\text { Comendador }\end{array}$ & Villel & $2.776 \mathrm{sj}$ & $\begin{array}{c}1.223 \mathrm{sj} .6 \text { d. restantes } \\
\text { en S. Bartolomé/88 }\end{array}$ \\
\hline Comunidad de aldeas & Torrelacárcel & $1.700 \mathrm{sj}$. & \\
\hline Concejo & Puebla de Valverde & $300 \mathrm{sj}$. & \\
\hline Mateo Torrecilla & El Pobo & $83 \mathrm{sj}$. & \\
\hline $\begin{array}{c}\text { Pascual Muñoz } \\
\text { y Domingo Bellido }\end{array}$ & Hinojosa & $500 \mathrm{sj}$. & \\
\hline Mateo Augusto & Torrelacárcel & $850 \mathrm{sj}$. & Tres plazos \\
\hline Lázaro León & Teruel & $100 \mathrm{sj}$. & \\
\hline Señor jurisdiccional & Escriche & 9 sj. 8 d. & 2 fustas \\
\hline Iglesia de San Martín & Teruel & $200 \mathrm{sj}$. & \\
\hline Pedro Jordán & Puebla de Valverde & $300 \mathrm{sj}$. & \\
\hline Juan Dolç & El Castellar & 131 sj. 4 d. & 25 fag. trigo 237 \\
\hline
\end{tabular}

235 A.R.V., Maestre Racional, reg. 8322, fols. 10r y 12v-13r.

236 A.R.V., Maestre Racional, reg. 8322, fols. 11r-14r.

23719 fanegas a razón de 5 sueldos 4 dineros y las 6 fanegas restante tasadas a 5 sueldos.

SEFARAD, vol. 80:1, enero-junio 2020, págs. 55-115. ISSN: 0037-0894. https://doi.org/10.3989/sefarad.020-003 


\begin{tabular}{|c|c|c|c|}
\hline Deudor & Localidad & Ingresos & Observaciones \\
\hline Martín Sebastián & Torrelacárcel & $20 \mathrm{sj}$. & $\begin{array}{c}2 \text { fag. trigo y } 2 \text { fag. } \\
\text { ordio }^{238}\end{array}$ \\
\hline Domingo Castiel y su hijo & Torrelacárcel & $500 \mathrm{sj}$. & $550 \mathrm{sj}$. \\
\hline $\begin{array}{c}\text { Pascual Silvestre y Juan } \\
\text { Simón }\end{array}$ & Albentosa & $100 \mathrm{sj}$. & $\begin{array}{c}\text { Segundo pago por } \\
\text { ganado }\end{array}$ \\
\hline El Ferreruelo, moro & Orrios & $203 \mathrm{sj}$. & $\begin{array}{c}35 \text { fag. trigo, } 2 \text { fag. } \\
\text { ordio y 18 fag. espelta } 239\end{array}$ \\
\hline Bartolomé Abad & Tortajada &
\end{tabular}

Tabla 5. Ejecución de bienes de Pedro Ruiz ${ }^{240}$

\begin{tabular}{|c|c|c|c|c|}
\hline Concepto & Deudor & Adquirente & Ingreso & Observaciones \\
\hline $\begin{array}{l}\text { Dos huertos } \\
\text { en el Molino } \\
\text { de La Torre }\end{array}$ & & Diego Vijuescas & $230 \mathrm{sj}$. & Con gravamen \\
\hline Cereales & & $\begin{array}{l}\text { Concejo de } \\
\text { Camarena }\end{array}$ & $255 \mathrm{sj}$. & \\
\hline 23 fag. trigo & $\begin{array}{c}\text { Miguel Pérez de } \\
\text { Cascant }\end{array}$ & Luis de Moros & $\begin{array}{c}126 \mathrm{sj} . \\
{[1 \mathrm{fag} .=5 \mathrm{sj} .6 \mathrm{~d} .]}\end{array}$ & \\
\hline Censal & $\begin{array}{l}\text { Luis Juan, } \\
\text { vecino de } \\
\text { Rubielos }\end{array}$ & & $300 \mathrm{sj}$. & Carnestolendas/ 88 \\
\hline Deuda & $\begin{array}{l}\text { Concejo de } \\
\text { Sarrión }\end{array}$ & & $1.211 \mathrm{sj} .4 \mathrm{~d}$. & \\
\hline Deuda & $\begin{array}{l}\text { Francisco Díez, } \\
\text { vecino de Teruel }\end{array}$ & & $30 \mathrm{sj}$. & \\
\hline
\end{tabular}

Tabla 6. Ejecución de deudas relativas a Gil Ruiz ${ }^{241}$

\begin{tabular}{|c|c|c|c|}
\hline Deudor & Localidad & Ingresos & Observaciones \\
\hline Micer Gonzalo Ruiz & Teruel & $250 \mathrm{sj}$. & Vino \\
\hline Pedro Miedes & Teruel (Arrabal) & $95 \mathrm{sj}$. & Resto de un pajar \\
\hline Sebastián de Orrios & {$[$ Teruel] } & $198 \mathrm{sj.} 4 \mathrm{~d}$. & Contrato \\
\hline Blas Buix y su mujer & Teruel & $200 \mathrm{sj}$. & Restan $246 \mathrm{sj}$. \\
\hline Concejo & Mezquita & $280 \mathrm{sj}$. & Pensión de dos años \\
\hline
\end{tabular}

2381 fanega de trigo $=5$ sueldos 4 dineros; 1 fanega de ordio $=3$ sueldos 4 dineros.

2391 fanega de trigo $=5$ sueldos; 1 fanega de espelta $=2$ sueldos.

240 A.R.V., Maestre Racional, reg. 8322, fol. 16r-v.

241 A.R.V., Maestre Racional, reg. 8322, fol. 18r-v. 


\begin{tabular}{|c|c|c|c|}
\hline Deudor & Localidad & Ingresos & Observaciones \\
\hline Pedro Martínez de Montagudo & Sarrión & $205 \mathrm{sj.} 10 \mathrm{~d}$. & \\
\hline Domingo Edo, mayor & Hinojosa & $400 \mathrm{sj}$. & De cuantía superior \\
\hline
\end{tabular}

Tabla 7. Bienes subastados y ejecutados a Francés de Puigmija ${ }^{242}$

\begin{tabular}{|c|c|c|c|c|}
\hline Concepto & Deudor & Adquirente & Percepción & Observaciones \\
\hline Unas casas & & $\begin{array}{c}\text { Convento de } \\
\text { S. Francisco de Teruel }\end{array}$ & $260 \mathrm{sj}$. & \\
\hline $\begin{array}{l}\text { Viña en los Planos } \\
\text { de San Cristóbal }\end{array}$ & & Miguel Pros, labrador & $35 \mathrm{sj}$. & \\
\hline Deuda & Pedro Besant ${ }^{243}$ & & $350 \mathrm{sj}$. & \\
\hline Trigo & $\begin{array}{l}\text { Miguel Cuenca y } \\
\text { Luis Besant, vecinos } \\
\text { de Torrijos }{ }^{244}\end{array}$ & & $30 \mathrm{sj}$. & $\begin{array}{c}6 \text { fag. trigo } \\
(1 \mathrm{fag} .=5 \mathrm{sj} .)\end{array}$ \\
\hline
\end{tabular}

Tabla 8. Patrimonio inmobiliario y fiduciario ${ }^{245}$

\begin{tabular}{|c|c|c|c|c|}
\hline Concepto & Ubicación & $\begin{array}{l}\text { Adquirente/ } \\
\text { deudor }\end{array}$ & Ingreso & Observaciones \\
\hline Unas casas & $\begin{array}{c}\text { Calle del } \\
\text { Chopo (Teruel) }\end{array}$ & $\begin{array}{l}\text { Pedro Pérez, } \\
\text { clérigo }\end{array}$ & $300 \mathrm{sj}$. & $\begin{array}{l}200 \mathrm{sj} . \text { del resto en } \\
\text { Carnestolendas } / 88\end{array}$ \\
\hline Un pajar & & $\begin{array}{l}\text { Miguel Claras, } \\
\text { labrador }\end{array}$ & $30 \mathrm{sj}$. & $\begin{array}{l}60 \mathrm{sj} . \text { del resto en } \\
\text { Carnestolendas/ } 88\end{array}$ \\
\hline $\begin{array}{c}\text { Dos «casalicios» } \\
\text { pequeños y contiguos }\end{array}$ & $\begin{array}{c}\text { Calle del } \\
\text { Chopo (Teruel) }\end{array}$ & $\begin{array}{l}\text { Juan Gil, } \\
\text { pregonero }\end{array}$ & {$[\ldots]$} & $\begin{array}{l}\text { Reversión a su } \\
\text { dueño }\end{array}$ \\
\hline Una parcela & $\begin{array}{l}\text { Val Paraíso } \\
\text { (Teruel) }\end{array}$ & Juan Gracián & $320 \mathrm{sj}$. & \\
\hline Una parcela & $\begin{array}{c}\text { Val Paraíso } \\
\text { (Teruel) }\end{array}$ & Juan Gracián & $30 \mathrm{sj}$. & $\begin{array}{l}300 \mathrm{sj} . \text { del resto en } \\
\text { Carnestolendas } / 88\end{array}$ \\
\hline Unas casas y heredad & Celadas & $\begin{array}{c}\text { Juan Pérez de } \\
\text { Caudé }\end{array}$ & $40 \mathrm{sj}$. & $\begin{array}{c}\text { Resto de la suma } \\
\text { total }\end{array}$ \\
\hline $\begin{array}{l}\text { Un solar y una } \\
\text { heredad }\end{array}$ & & Juan Íñigo & $490 \mathrm{sj}$. & \\
\hline Arriendo de primicia & Álava & Concejo & $75 \mathrm{sj}$. & \\
\hline Deuda & El Pobo & Juan Piquer & $160 \mathrm{sj}$. & \\
\hline Deuda & Visiedo & Antón Sánchez & 702 sj. 8 d. & \\
\hline
\end{tabular}

242 A.R.V., Maestre Racional, reg. 8322, fol. 19r.

243 Deuda conjunta con Diego de Toledo.

244 Adeudado a Manuel Pugmija.

245 A.R.V., Maestre Racional, reg. 8322, fols. 20r-22v. 


\begin{tabular}{|c|c|c|c|c|}
\hline Concepto & Ubicación & $\begin{array}{l}\text { Adquirente/ } \\
\text { deudor }\end{array}$ & Ingreso & Observaciones \\
\hline Deuda & Sarrión & García Valero & $85 \mathrm{sj}$. & \\
\hline Deuda & [Teruel] & {$[\ldots]$} & $80 \mathrm{sj}$. & \\
\hline Deuda & [Teruel] & $\begin{array}{c}\text { Jaime Berbegal, } \\
\text { vicario }\end{array}$ & $17 \mathrm{sj}$. & $\begin{array}{l}\text { A su hijo Gil de } \\
\text { Gonzalo }\end{array}$ \\
\hline Ganado & Bronchales & $\begin{array}{c}\text { Fernando Valero } \\
\text { y Bartolomé de } \\
\text { Anguita }\end{array}$ & $100 \mathrm{sj}$. & \\
\hline Ganado & Bronchales & Pedro Cubel & $95 \mathrm{sj} .9 \mathrm{~d}$. & \\
\hline Ganado & Bronchales & Pedro Soriano & 194 sj. 6 d. & Restante del total \\
\hline $\begin{array}{l}\text { Dos vacas, dos } \\
\text { novillos y tres } \\
\text { becerros }\end{array}$ & Bronchales & {$[\ldots]$} & $295 \mathrm{sj}$. & Contrato parciario \\
\hline 18 fag. trigo & Álava & Miguel Mateu & $99 \mathrm{sj}$. & 1 fag. $=5$ sj. 6 d. \\
\hline 7 fag. centeno & Torrelacárcel & Pascual Rubio & $21 \mathrm{sj}$. & 1 fag. $=3 \mathrm{sj}$. \\
\hline Loguero de casas & $\begin{array}{l}\text { Calle del } \\
\text { Chopo }\end{array}$ & Martín Çapatero & $22 \mathrm{sj} .5 \mathrm{~d}$. & 11 meses \\
\hline Deuda & Torrelacárcel & Pascual Rubio & 9 sj. & \\
\hline $\begin{array}{l}\text { Diezmo: } 128 \text { fag. } \\
\text { trigo, } 41 \text { fag. centeno } \\
\text { y } 13 \text { fag. } 2 \text { c. cebada }\end{array}$ & Álava & $\begin{array}{l}\text { Miguel Mateu, } \\
\text { recaudador del } \\
\text { diezmo }\end{array}$ & $\begin{array}{c}90 \mathrm{sj.} \\
{[18 \mathrm{fag} . \text { trigo }} \\
1 \text { fag.= } 5 \mathrm{sj} .]\end{array}$ & $\begin{array}{l}\text { Pendiente el resto, } \\
\text { salvo } 10 \text { fag. trigo } \\
\text { por gastos de } \\
\text { gestión }\end{array}$ \\
\hline
\end{tabular}

Tabla 9. Inmuebles subastados pertenecientes a Berenguer Ram ${ }^{246}$

\begin{tabular}{|c|c|c|c|c|c|}
\hline Inmuebles & Ubicación & Tasación & Adquirente & Ingresos & Observaciones \\
\hline $\begin{array}{c}\text { Bodegas y casa } \\
\text { con cubas y } \\
\text { fusta }\end{array}$ & $\begin{array}{c}\text { Junto a la } \\
\text { Puerta de } \\
\text { Zaragoza }\end{array}$ & $2.560 \mathrm{sj}$. & $\begin{array}{c}\text { Pedro Maestro, } \\
\text { vecino de } \\
\text { Teruel }\end{array}$ & $1.600 \mathrm{sj.}$ & $\begin{array}{c}\text { El resto en } \\
\text { Todos los } \\
\text { Santos/88 }\end{array}$ \\
\hline $\begin{array}{c}\text { Una casa, } \\
\text { botiga y corral } \\
\text { con casilla }\end{array}$ & $\begin{array}{c}\text { La Plaza y } \\
\text { calle Rossell }\end{array}$ & $3.900 \mathrm{sj}$. & $\begin{array}{c}\text { Juan Alamán y } \\
\text { Lluch Gregorio }\end{array}$ & $3.900 \mathrm{sj.}$ & $\begin{array}{c}\text { Incluye el } \\
\text { mobiliario } 247\end{array}$ \\
\hline $\begin{array}{c}\text { Unas casas } \\
\text { muy sotiles }\end{array}$ & $\begin{array}{c}\text { Frente a la } \\
\text { iglesia de } \\
\text { Villel }\end{array}$ & $150 \mathrm{sj}$. & Pere Antoni & --- & $\begin{array}{c}\text { Pago Carnesto- } \\
\text { lendas/88 }\end{array}$ \\
\hline
\end{tabular}

246 A.R.V., Maestre Racional, reg. 8322, fols. 23r-24v y 27v-28r. Se utiliza un asterisco $\left(^{*}\right)$ sobre el inmueble cuando pesa sobre él algún gravamen. Cuando se indica $(* *)$ se alude a la cantidad restante del precio convenido.

247 «Con mobles de steras caxas y fusta que en las dichas casas stavan». A.H.N., Sección Inquisición, Valencia, leg. 546/5, fol. 23r. 


\begin{tabular}{|c|c|c|c|c|c|}
\hline Inmuebles & Ubicación & Tasación & Adquirente & Ingresos & Observaciones \\
\hline Viña y albar & {$[\ldots]$} & $150 \mathrm{sj}$. & $\begin{array}{c}\text { Juan García, } \\
\text { tejedor }\end{array}$ & $150 \mathrm{sj}$. & \\
\hline Unas casas & {$[\ldots]$} & $200 \mathrm{sj}$. & León Maçot & $200 \mathrm{sj}$. & \\
\hline Unas casas & Judería & $160 \mathrm{sj}$. & Leví Açe & $160 \mathrm{sj}$. & \\
\hline Mobiliario & $\begin{array}{l}\text { Vivienda } \\
\text { familiar }\end{array}$ & $147 \mathrm{sj} .10 \mathrm{~d}$. & & 147 sj. 10 d. & $\begin{array}{l}\text { Restituidos por } \\
\text { Alonso de Mesa }\end{array}$ \\
\hline Bodega & $\begin{array}{l}\text { Puerta de } \\
\text { Zaragoza }\end{array}$ & 92 sj. 9 d. & $\begin{array}{l}\text { Pascual de } \\
\text { Alda }\end{array}$ & 92 sj. 9 d. & Alquiler \\
\hline Una tienda & $\begin{array}{l}\text { Puerta de } \\
\text { Zaragoza }\end{array}$ & 44 sj. & Erinet, sillero & $44 \mathrm{sj}$. & Alquiler \\
\hline $\begin{array}{c}\text { Botiga de } \\
\text { Fernando Ram }\end{array}$ & {$[\ldots]$} & $14 \mathrm{sj}$. & $\begin{array}{l}\text { Juan Valero, } \\
\text { mayor }\end{array}$ & $14 \mathrm{sj}$. & Mercancías \\
\hline $\begin{array}{c}\text { Botiga de } \\
\text { Fernando Ram }\end{array}$ & {$[\ldots]$} & $8 \mathrm{sj}$. & Miguel Teresa & $8 \mathrm{sj}$. & Mercancías \\
\hline
\end{tabular}

Tabla 10. Censales y deudas líquidas 248

\begin{tabular}{|c|c|c|c|c|c|}
\hline Deudor & Localidad & Capital & Renta & Ingreso & Observaciones \\
\hline$[\ldots]$ & {$[\ldots]$} & $40.000 \mathrm{sj}$. & $2.000 \mathrm{sj}$. & $4.000 \mathrm{sj}$. & $1486 / 87$ \\
\hline Generalidades & Zaragoza & {$[\ldots]$} & $1.000 \mathrm{sj}$. & $1.000 \mathrm{sj}$. & 1486 \\
\hline Generalidades & Zaragoza & {$[\ldots]$} & $1.000 \mathrm{sj}$. & $1.000 \mathrm{sj}$. & 1487 \\
\hline $\begin{array}{c}\text { Antón de } \\
\text { Vallecroche }\end{array}$ & Teruel & $300 \mathrm{sj}$. & $25 \mathrm{sj}$. & $375 \mathrm{sj}$. & $\begin{array}{l}\text { Amortización y } \\
3 \text { anualidades }\end{array}$ \\
\hline $\begin{array}{l}\text { Comunidad de } \\
\text { aldeas }\end{array}$ & Teruel & {$[\ldots]$} & $250 \mathrm{sj}$. & $500 \mathrm{sj}$. & 2 años \\
\hline Felipe Guillén & {$[\ldots]$} & {$[\ldots]$} & $125 \mathrm{sj}$. & $250 \mathrm{sj}$. & 2 años \\
\hline $\begin{array}{c}\text { Berenguer } \\
\text { Asensio, rector }\end{array}$ & Allepuz & {$[\ldots]$} & 41 sj. 8 d. & 83 sj. 4 d. & 2 años \\
\hline Juan Ezquierdo & Monteagudo & {$[\ldots]$} & 51 sj. $8 \mathrm{~d}$. & 103 sj. 4 d. & 2 años 249 \\
\hline $\begin{array}{c}\text { Juan Pérez de } \\
\text { Martín }\end{array}$ & Allepuz & {$[\ldots]$} & $250 \mathrm{sj}$. & $500 \mathrm{sj}$. & 2 años \\
\hline Concejo & Cubla & {$[\ldots]$} & 181 sj. 8 d. & 363 sj. 4 d. & 2 años \\
\hline
\end{tabular}

248 A.R.V., Maestre Racional, reg. 8322, fols. 23v-24r y 26v-27r.

249 Adeudadas a Fernando Ram. 
Tabla 11. Deudas y transacciones comerciales ${ }^{250}$

\begin{tabular}{|c|c|c|c|c|}
\hline Deudor & Localidad & Concepto & Ingresos & Observaciones \\
\hline Juan Climent & Yesa & $\begin{array}{c}\text { Aval de una provisión de } \\
\text { lana }\end{array}$ & $90 \mathrm{sj}$. & \\
\hline $\begin{array}{c}\text { Pascual } \\
\text { Ezquierdo }\end{array}$ & Monteagudo & Un buey & $90 \mathrm{sj}$. & \\
\hline $\begin{array}{l}\text { Domingo } \\
\text { Soriano }\end{array}$ & Riodeva & $\begin{array}{c}\text { Partición a medias de } \\
\text { unas yeguas }\end{array}$ & $100 \mathrm{sj}$. & \\
\hline Concejo & Munébrega & Arriendo del azafrán & $2.506 \mathrm{sj}$ & $\begin{array}{l}7.571 \text { sj. restantes en } \\
\text { Navidad/88-90 }\end{array}$ \\
\hline Juan Despills & Cedrillas & $\begin{array}{l}50 \text { fag. trigo } 251 \\
(1 \text { fag. }=5 \mathrm{sj} .)\end{array}$ & $140 \mathrm{sj}$. & $\begin{array}{l}110 \text { sj. restantes en } \\
\text { Pascua Florida/ } 88\end{array}$ \\
\hline Ferrando Dolç & Cedrillas & $\begin{array}{l}10 \text { fag. centeno } \\
(1 \text { fag. }=3 \mathrm{sj} .)\end{array}$ & $20 \mathrm{sj}$ & $\begin{array}{l}10 \text { sj. restantes en } \\
\text { Carnescultas } / 88\end{array}$ \\
\hline $\begin{array}{l}\text { Juan Ram, } \\
\text { mercader }\end{array}$ & Teruel & Aval de la botiga & $1.200 \mathrm{sj}$. & \\
\hline Juan Nadal & El Pobo & $\begin{array}{l}40 \text { fag. } 2 \text { cuart. trigo } \\
(1 \text { fag. }=5 \mathrm{sj} .)\end{array}$ & $50 \mathrm{sj}$. & $\begin{array}{l}150 \text { sj. restantes } \\
\text { en } 1488\end{array}$ \\
\hline $\begin{array}{c}\text { Pascual } \\
\text { Ezquierdo }\end{array}$ & Monteagudo & $\begin{array}{c}3 \text { fag. trigo } \\
(1 \mathrm{fag} .=5 \mathrm{sj} .)\end{array}$ & $15 \mathrm{sj}$. & \\
\hline Jaime Izquierdo & Monteagudo & $\begin{array}{c}3 \text { fag. trigo } \\
(1 \text { fag. }=3 \text { sj. })\end{array}$ & $9 \mathrm{sj}$. & \\
\hline Blas Guillén & Monteagudo & $\begin{array}{l}17 \text { fag. } 3 \text { cuart. trigo } \\
(1 \text { fag. }=5 \mathrm{sj} .) \\
13 \text { fag. } 3 \text { cuart. ordio } \\
(1 \mathrm{fag} .=3 \mathrm{sj} .) \\
13 \text { fag. espelta }\end{array}$ & $131 \mathrm{sj}$. & $\begin{array}{l}\text { Abonará la espelta } \\
\text { en } 1488\end{array}$ \\
\hline Juan Aguilar & Monteagudo & $\begin{array}{l}53 \text { fag. } 2 \text { cuart. trigo } \\
(1 \text { fag. }=5 \text { sj. } 2 \text { d. }) \\
23 \text { fag. } 8 \text { cuart. ordio } \\
(1 \text { fag. }=3 \text { sj. }) \\
3 \text { cuart. espelta } \\
(1 \text { fag. }=1 \text { sj. } 11 \text { d. })\end{array}$ & $335 \mathrm{sj}$. & $\begin{array}{c}24 \text { sj. } 7 \text { d. restantes } \\
\text { en Pascua } \\
\text { Florida/1488 }\end{array}$ \\
\hline Benet Senyor & Caudé & $\begin{array}{c}35 \text { fag. trigo } \\
(1 \text { fag. }=5 \text { sj. }) \\
33 \text { fag. centeno }\end{array}$ & $100 \mathrm{sj}$. & $\begin{array}{l}\text { Restan por pagar } \\
15 \text { fag. de trigo } \\
\text { y el centeno/1488 }\end{array}$ \\
\hline Juan Ximeno & Santa Olaya & $\begin{array}{c}15 \text { fag. centeno } \\
(1 \text { fag. }=2 \text { sj. } 6 \text { d. })\end{array}$ & $30 \mathrm{sj}$. & $\begin{array}{l}\text { Restan } 3 \text { fag. } \\
\text { centeno/1488 }\end{array}$ \\
\hline Mateo Polo & El Pobo & Deuda & 36 sj. $8 \mathrm{~d}$. & \\
\hline
\end{tabular}

250 A.R.V., Maestre Racional, reg. 8322, fols. 24r-28r.

251 En Teruel: 1 cahíz $=5$ fanegas; 1 fanega $=4$ cuartales; 1 cuartal $=6$ almudes. La fanega como media tradicional de áridos equivale a 21,40 litros, mientras que el cuartal tiene una capacidad de 5,35 litros. 


\begin{tabular}{|c|c|c|c|c|}
\hline Deudor & Localidad & Concepto & Ingresos & Observaciones \\
\hline Jaime Cervera & {$[\ldots]$} & Deuda & $85 \mathrm{sj}$. & $\begin{array}{c}\text { Acreedor Berenguer } \\
\text { Ram y Alonso de } \\
\text { Santángel }\end{array}$ \\
\hline Miguel de Pales & Tortajada & Deuda & $650 \mathrm{sj}$. & $\begin{array}{c}\text { Acreedor Fernando } \\
\text { Ram }\end{array}$ \\
\hline Pascual Vicent & Rubielos & Deuda & $379 \mathrm{~s}$. & \\
\hline $\begin{array}{l}\text { Pedro Estevan, } \\
\text { vicario }\end{array}$ & Sarrión & Deuda & $145 \mathrm{sj}$. & $\begin{array}{l}\text { Acreedor Fernando } \\
\text { Ram }\end{array}$ \\
\hline Gaspar Millán & Teruel & Una heredad & $300 \mathrm{sj}$. & $\begin{array}{l}\text { Restante del precio } \\
\text { pactado }\end{array}$ \\
\hline Pedro Adrián & Orrios & $\begin{array}{c}3 \text { fag. trigo, } 2 \text { fag. } \\
\text { centeno y } 3 \text { fag. espelta }\end{array}$ & 18 sj. 3 d. & \\
\hline Juan de Lamata & Teruel & 3 docenas de cabirones & $22 \mathrm{sj}$. & $\begin{array}{c}\text { En la bodega de } \\
\text { Berenguer Ram, en la } \\
\text { Puerta de Zaragoza }\end{array}$ \\
\hline Pascual de Xera & Cuevas & Deuda & $11 \mathrm{sj}$. & $\begin{array}{c}\text { Acreedor Fernando } \\
\text { Ram }\end{array}$ \\
\hline $\begin{array}{l}\text { Juan López de } \\
\text { Laserra }\end{array}$ & {$[\ldots]$} & Deuda & 27 sj. 2 d. & \\
\hline
\end{tabular}

Tabla 12. Inmuebles y heredades ${ }^{252}$

\begin{tabular}{|c|c|c|c|c|}
\hline $\begin{array}{c}\text { Inmueble/ } \\
\text { heredad }\end{array}$ & Ubicación & Tasación & Adquirente & Observaciones \\
\hline Unas casas & Judería & $300 \mathrm{sj}$. & Mossé Maçot & $\begin{array}{c}\text { Abona } 166 \text { sj. } 8 \mathrm{~d} . ; \text { el } \\
\text { resto en Pascua Florida/88 }\end{array}$ \\
\hline Unas casas & Allepuz & $170 \mathrm{sj}$. & Pedro Capilla & Censo de $2 \mathrm{sj}$. \\
\hline Un huerto & {$[\ldots]$} & $140 \mathrm{sj}$. & Miguel Muñoz & \\
\hline
\end{tabular}

Tabla 13. Intereses crediticios, pecuarios y cerealísticos ${ }^{253}$

\begin{tabular}{|c|c|c|c|c|}
\hline Deudor & Localidad & Concepto & Cuantía & Observaciones \\
\hline Juan Ramo & Fababuj & $\begin{array}{c}\text { Partición de ganado } \\
\text { vacuno }\end{array}$ & $133 \mathrm{sj}$. & $\begin{array}{c}\text { Abona } 110 \mathrm{sj} . ; \text { el resto } \\
\text { en } 1488\end{array}$ \\
\hline $\begin{array}{c}\text { Miguel de } \\
\text { Campos }\end{array}$ & Teruel & Heredad de Fababuj & $275 \mathrm{sj}$. & $\begin{array}{c}\text { Restan } 65 \text { sj; reclama } \\
5 \text { fag. trigo }\end{array}$ \\
\hline Jurados & El Pobo & $\left.\begin{array}{c}220 \mathrm{fag} .4 \text { cuart. trigo } \\
(1 \mathrm{fag} .\end{array} \mathbf{5 j .}\right)$ & $1.074 \mathrm{sj.} 2 \mathrm{~d}$. & El resto pendiente 254 \\
\hline
\end{tabular}

252 A.R.V., Maestre Racional, reg. 8322, fol. 29r.

253 A.R.V., Maestre Racional, reg. 8322, fols. 29r-30v.

254 Vende a terceros un total de 206 fanegas, 3 cuartales y 2 almudes de trigo. 


\begin{tabular}{|c|c|c|c|c|}
\hline Deudor & Localidad & Concepto & Cuantía & Observaciones \\
\hline Jurados & El Pobo & $\begin{array}{c}51 \text { fag. espelta } \\
(1 \text { fag. }=2 \text { sj. } 2 \text { d. }) \\
24 \text { fag. espelta } \\
(1 \text { fag. }=2 \text { sj. })\end{array}$ & $269 \mathrm{sj}$. & \\
\hline Jurados & El Pobo & $\begin{array}{c}35 \text { fag. ordio } \\
(1 \text { fag. }=2 \text { sj. } 6 \text { d. })\end{array}$ & $\begin{array}{c}30 \mathrm{sj} . \\
{[12 \mathrm{fag} .]}\end{array}$ & $\begin{array}{c}\text { El resto a Juan } \\
\text { Camanyas, vecino de } \\
\text { Teruel }\end{array}$ \\
\hline Antón Nadal & El Pobo & $\begin{array}{c}16 \text { fag. trigo } \\
(1 \mathrm{fag} .=5 \mathrm{sj} .)\end{array}$ & $80 \mathrm{sj}$. & \\
\hline Juan Sanz & El Pobo & $\begin{array}{l}10 \text { fag. trigo } \\
(1 \mathrm{fag} .=5 \mathrm{sj} .)\end{array}$ & $50 \mathrm{sj}$. & \\
\hline Pedro Nicolás & Monteagudo & $\begin{array}{c}6 \text { fag. trigo } \\
(1 \mathrm{fag} .=5 \mathrm{sj} .6 \mathrm{~d} .)\end{array}$ & $33 \mathrm{sj}$. & \\
\hline Sancho Burriel & Mezquita & $\begin{array}{l}30 \text { fag. cebada } \\
(1 \text { fag. }=2 \text { sj. })\end{array}$ & $60 \mathrm{sj}$. & \\
\hline $\begin{array}{l}\text { Francisco } \\
\text { Navarret }\end{array}$ & Camarena & $\begin{array}{c}4 \text { fag. trigo } \\
(1 \text { fag. }=5 \text { sj. } 6 \text { d. }) \\
5 \text { fag. trigo } \\
(1 \text { fag. }=5 \mathrm{sj} .)\end{array}$ & $47 \mathrm{sj}$. & \\
\hline Juan Aguilar & Monteagudo & Deuda & 86 sj. 6 d. & \\
\hline Juan Pastor & San Agustín & Deuda & $50 \mathrm{sj}$. & \\
\hline Antón Navarro & Fortanete & Deuda & $148 \mathrm{sj} .4 \mathrm{~d}$. & $\begin{array}{c}\text { Suma de mayor } \\
\text { cuantía }\end{array}$ \\
\hline $\begin{array}{l}\text { Domingo } \\
\text { Ferrera }\end{array}$ & Fortanete & Deuda & $146 \mathrm{sj}$. & \\
\hline
\end{tabular}

Tabla 14. Préstamos y censales ${ }^{255}$

\begin{tabular}{|c|c|c|c|}
\hline Deudor & Localidad & Cuantía & Observaciones \\
\hline Martín Sarzo, soguero & Daroca & $\begin{array}{c}40 \mathrm{sj} . \\
{[\text { Censal }]}\end{array}$ & Renta de 1486/87 \\
\hline Domingo Pastor y Juan Pérez & San Agustín & $200 \mathrm{sj}$. & $\begin{array}{c}\text { Adeudados a su suegra } \\
\text { Isabel Navarro }\end{array}$ \\
\hline Pascual Silvestre, mayor & Albentosa & $500 \mathrm{sj}$. & \\
\hline
\end{tabular}

255 A.R.V., Maestre Racional, reg. 8322, fol. 32r. 
Tabla 15. Orfebrería y ajuar doméstico ${ }^{256}$

\begin{tabular}{|c|c|c|c|c|}
\hline Ajuar & Peso & Ingreso & Adquirente & Observaciones \\
\hline $\begin{array}{l}\text { Ropa dorada de } \\
\text { talla grande }\end{array}$ & $\begin{array}{c}1 \text { marco } 3 \text { onzas } \\
1 \text { arienzo } \\
{[1 \text { onza }=16 \text { sj. }]}\end{array}$ & $177 \mathrm{sj}$. & $\begin{array}{c}\text { Lucas Gregorio, } \\
\text { mercader de Teruel }\end{array}$ & Marco de Teruel \\
\hline $\begin{array}{l}\text { Ropa dorada de } \\
\text { talla pequeña }\end{array}$ & $\begin{array}{l}7 \text { onzas } 1 \text { cuarto } \\
1 \text { arienzo } \\
{[1 \text { marco }=6 \mathrm{fl} .]}\end{array}$ & 109 sj. 9 d. & {$[\ldots]$ de Valencia } & $\begin{array}{l}\text { Marco de } \\
\text { Barcelona }\end{array}$ \\
\hline Picher antiguo & $\begin{array}{c}2 \text { marcos } \\
{[1 \mathrm{marco}=5 \text { fl. } 10 \mathrm{~s} .]}\end{array}$ & $220 \mathrm{sj}$. & $\begin{array}{l}\text { Juan Sánchez, } \\
\text { platero }\end{array}$ & $\begin{array}{l}\text { Marco de } \\
\text { Valencia }\end{array}$ \\
\hline Picher moderno & $\begin{array}{l}1 \text { marco } 5 \text { onzas } \\
{[1 \text { marco }=6 \mathrm{fl} .]}\end{array}$ & $195 \mathrm{sj}$. & $\begin{array}{l}\text { Micer Antich } \\
\text { Boqui }\end{array}$ & Marco de Teruel \\
\hline Plato & $\begin{array}{c}1 \text { marco } 1 \text { onza } \\
2 \text { cuartos } 2 \text { arienzos }\end{array}$ & \multirow{6}{*}{896 sj. 9 d. } & \multirow{6}{*}{$\begin{array}{l}\text { Juan Sánchez, } \\
\text { platero }\end{array}$} & \multirow{6}{*}{$\begin{array}{c}\text { Marco de } \\
\text { Valencia } \\
{[1 \text { marco = }} \\
5 \text { fl. } 11 \mathrm{~s} .]\end{array}$} \\
\hline $\begin{array}{l}\text { Seis tazas sin } \\
\text { grabar }\end{array}$ & $\begin{array}{c}4 \text { marcos } 4 \text { onzas } \\
3 \text { cuartos } 3 \text { arienzos }\end{array}$ & & & \\
\hline $\begin{array}{l}\text { Salero con su } \\
\text { cobertor }\end{array}$ & $\begin{array}{c}7 \text { onzas } \\
3 \text { cuartos }\end{array}$ & & & \\
\hline $\begin{array}{l}\text { Un perfumador } \\
\text { pequeño }\end{array}$ & $\begin{array}{c}1 \text { onza } 2 \text { cuartos } \\
1 \text { arienzo }\end{array}$ & & & \\
\hline Siete cucharillas & 5 onzas & & & \\
\hline $\begin{array}{l}\text { Dos manillas de } \\
\text { plata }\end{array}$ & 3 onzas 3 cuartos & & & \\
\hline $\begin{array}{l}\text { Correa ancha de } \\
\text { parge, pardillos y } \\
\text { barras }\end{array}$ & 13 onzas 3 arienzos & \multirow{7}{*}{$532 \mathrm{sj}}$. & \multirow{7}{*}{$\begin{array}{l}\text { Lucas Gregorio, } \\
\text { mercader de Teruel }\end{array}$} & \multirow{7}{*}{1 onza $=11 \mathrm{sj}}$. \\
\hline $\begin{array}{l}\text { Correa de parge } \\
\text { negro y verde }\end{array}$ & $\begin{array}{l}6 \text { onzas } 1 \text { cuarto } \\
3 \text { arienzos }\end{array}$ & & & \\
\hline $\begin{array}{c}\text { Correa azur con } \\
\text { cruceta y patena } \\
\text { de plata }\end{array}$ & 1 onza 1 cuarto & & & \\
\hline $\begin{array}{l}\text { Correa de parge } \\
\text { bermejo }\end{array}$ & 7 onzas 2 cuartos & & & \\
\hline $\begin{array}{l}\text { Correa plateada } \\
\text { de parge verde }\end{array}$ & 5 onzas & & & \\
\hline $\begin{array}{c}\text { Correa plateada } \\
\text { de parge verde y } \\
\text { blanco }\end{array}$ & $\begin{array}{l}11 \text { onzas } 2 \text { cuartos } \\
1 \text { arienzo }\end{array}$ & & & \\
\hline $\begin{array}{l}\text { Correa estrecha } \\
\text { de parge bermejo }\end{array}$ & $\begin{array}{c}2 \text { onzas } 2 \text { cuartos } \\
1 \text { arienzo }\end{array}$ & & & \\
\hline
\end{tabular}

256 A.R.V., Maestre Racional, reg. 8322, fols. 34r-35r.

SEFARAD, vol. 80:1, enero-junio 2020, págs. 55-115. ISSN: 0037-0894. https://doi.org/10.3989/sefarad.020-003 


\begin{tabular}{|c|c|c|c|c|}
\hline Ajuar & Peso & Ingreso & Adquirente & Observaciones \\
\hline $\begin{array}{c}\text { Dos zafiros de } \\
\text { coral }\end{array}$ & 5 onzas 2 cuartos & $55 \mathrm{sj}$. & $\begin{array}{c}\text { Juan Pérez y } \\
\text { Rodrigo de } \\
\text { Segovia }\end{array}$ & 1 onza $=10 \mathrm{sj}$. \\
\hline Mobiliario & & $665 \mathrm{sj}$. & & Según inventario \\
\hline
\end{tabular}

Tabla 16. Deudas de las aldeas de Teruel con los conversos condenados 257

\begin{tabular}{|c|c|c|c|c|}
\hline Deudor & Localidad & Importe & Ingresos & Aplazamientos \\
\hline Aljama judía & Teruel & 5.302 sj. 4 d. & $5.000 \mathrm{sj}$. & Carnestolendas/88 \\
\hline Concejo & Teruel & $\begin{array}{c}1.815 \mathrm{sj} .8 \mathrm{~d} \text {. [arriendo } \\
\text { de carnicerías] }\end{array}$ & 1.815 sj. 8 d. & \\
\hline Diversos vecinos & Santed & 827 sj. & $667 \mathrm{sj}$. & $\begin{array}{l}\text { Carnestolendas y } \\
\text { Corpus } \text { Christi/88 }\end{array}$ \\
\hline Diversos vecinos & Orrios & $447 \mathrm{sj}$. & $447 \mathrm{sj}$. & \\
\hline Ibañez Valero & Valconchán & $\begin{array}{c}\text { Luis de Santángel } \\
{[193 \text { sj. } 6 \text { d.] }} \\
\text { Diego de Toledo }[20 \text { sj.] }\end{array}$ & $20 \mathrm{sj}$. & $\begin{array}{l}\text { Carnestolendas y } \\
\text { Corpus } \text { Christi/88 }\end{array}$ \\
\hline $\begin{array}{l}\text { Pedro de Guerta y } \\
\text { Ferrando de Acheo }\end{array}$ & Used & $\begin{array}{c}\text { Diego de Toledo } \\
\text { [194 sj.] }\end{array}$ & $64 \mathrm{sj}$. & $\begin{array}{l}\text { Carnestolendas y } \\
\text { Corpus } \text { Christi/88 }\end{array}$ \\
\hline $\begin{array}{c}\text { Miguel López y } \\
\text { Sancho de Heredia }\end{array}$ & Daroca & $\begin{array}{c}\text { Diego de Toledo } \\
{[200 \mathrm{sj} .]}\end{array}$ & $100 \mathrm{sj}$. & Corpus Christi/88 \\
\hline Juan Ferrández & Castejón & $\begin{array}{c}\text { Diego de Toledo } \\
{[60 \mathrm{sj} .]}\end{array}$ & $60 \mathrm{sj}$. & \\
\hline $\begin{array}{l}\text { Juan García y } \\
\text { Juan Beuna }\end{array}$ & Castelberuco & $\begin{array}{l}\text { Gil de Gonzalo Ruiz } \\
{[18 \mathrm{sj} .]}\end{array}$ & $18 \mathrm{sj}$. & \\
\hline Diversos vecinos & Gallocanta & $\begin{array}{l}\text { Gil de Gonzalo Ruiz y } \\
\text { otros }[522 \mathrm{sj} .]\end{array}$ & $269 \mathrm{sj}$. & $\begin{array}{l}\text { Carnestolendas y } \\
\text { Corpus } \text { Christi/88 }\end{array}$ \\
\hline Diversos vecinos & Odón & $\begin{array}{l}\text { Gil de Gonzalo Ruiz y } \\
\text { otros }[307 \mathrm{sj} .]\end{array}$ & $307 \mathrm{sj}$. & \\
\hline Pedro Ruvio & $\begin{array}{l}\text { Torralba de } \\
\text { los Sisones }\end{array}$ & $17 \mathrm{sj}$. [lana] & $17 \mathrm{sj}$. & \\
\hline Diversos vecinos & Bello & $2.454 \mathrm{sj}$. & $1.596 \mathrm{sj}$. & $\begin{array}{l}\text { Carnestolendas y } \\
\text { Corpus } \text { Christi/88 }\end{array}$ \\
\hline Diversos vecinos & Blancas & 519 sj. $11 \mathrm{~d}$. & $519 \mathrm{sj.} 11 \mathrm{~d}$. & \\
\hline Diversos vecinos & Ojos Negros & $2.411 \mathrm{sj} .11 \mathrm{~d}$. & $1.780 \mathrm{sj} .11 \mathrm{~d}$. & $\begin{array}{l}\text { Carnestolendas y } \\
\text { Corpus } \text { Christi/88 }\end{array}$ \\
\hline Diversos vecinos & Pozuelo & $465 \mathrm{sj}$. & $31 \mathrm{sj}$. & $\begin{array}{l}\text { Carnestolendas y } \\
\text { Corpus } \text { Christi/88 }\end{array}$ \\
\hline Diversos vecinos & $\begin{array}{l}\text { Villar del } \\
\text { Salz }\end{array}$ & $441 \mathrm{sj}$. & $141 \mathrm{sj}$. & $\begin{array}{l}\text { Carnestolendas y } \\
\text { Corpus } \text { Christi/88 }\end{array}$ \\
\hline
\end{tabular}

257 A.R.V., Maestre Racional, reg. 8322, fols. 36r-42v. 


\begin{tabular}{|c|c|c|c|c|}
\hline Deudor & Localidad & Importe & Ingresos & Aplazamientos \\
\hline Diversos vecinos & Villafranca & $632 \mathrm{sj}$. & $117 \mathrm{sj}$. & $\begin{array}{l}\text { Carnestolendas y } \\
\text { Corpus } \text { Christi/88 }\end{array}$ \\
\hline Diversos vecinos & $\begin{array}{c}\text { Monreal del } \\
\text { Campo }\end{array}$ & 1.333 sj. 3 d. & $955 \mathrm{sj}$. & $\begin{array}{l}\text { Carnestolendas y } \\
\text { Corpus } \text { Christi/88 }\end{array}$ \\
\hline Diversos vecinos & Torrijo & 818 sj. 8 d. & $132 \mathrm{sj}$. & $\begin{array}{l}\text { Carnestolendas y } \\
\text { Corpus } \text { Christi/88 }\end{array}$ \\
\hline $\begin{array}{l}\text { Lorenzo de Sant } \\
\text { Martín y Miguel } \\
\text { Gorbe }\end{array}$ & Caminreal & $380 \mathrm{sj}$. & $160 \mathrm{sj}$. & $\begin{array}{l}\text { Carnestolendas y } \\
\text { Corpus } \text { Christi/88 }\end{array}$ \\
\hline Juan Sala ${ }^{258}$ & Caminreal & $4.234 \mathrm{sj}$ & $1.700 \mathrm{sj}$. & $\begin{array}{l}\text { Carnestolendas y } \\
\text { Corpus } \text { Christi/88 }\end{array}$ \\
\hline Diversos vecinos & $\begin{array}{c}\text { Fuentes } \\
\text { Claras }\end{array}$ & $3.045 \mathrm{sj}$ & $1.360 \mathrm{sj}$ & $\begin{array}{l}\text { Carnestolendas y } \\
\text { Corpus } \text { Christi/88 }\end{array}$ \\
\hline $\begin{array}{c}\text { Valero y Pero } \\
\text { Ramo }\end{array}$ & El Poyo & $\begin{array}{l}\text { Luis de Santángel } \\
{[150 \mathrm{sj} .]}\end{array}$ & $50 \mathrm{sj}$. & $\begin{array}{l}\text { Carnestolendas y } \\
\text { Corpus } \text { Christi/88 }\end{array}$ \\
\hline $\begin{array}{l}\text { Lorenzo Gonzalo } \\
\text { y Juan Ruzaquino }\end{array}$ & Bañón & $97 \mathrm{sj}$. & $97 \mathrm{sj}$. & \\
\hline Domingo Pascual & $\begin{array}{c}\text { Torre } \\
\text { Conejos }\end{array}$ & Diego de Toledo [48 sj.] & $48 \mathrm{sj}$. & \\
\hline $\begin{array}{l}\text { Lope Doria, Juan } \\
\text { Lario y otros }\end{array}$ & Cosa & $414 \mathrm{sj}$. & $414 \mathrm{sj}$ & \\
\hline Jaime Galindo & Pancrudo & $\begin{array}{l}\text { Ferrando de Toledo } \\
\text { [180 sj. } 6 \text { d. }]\end{array}$ & 180 sj. $6 \mathrm{~d}$. & \\
\hline Diversos vecinos & Cuencabuena & $2.104 \mathrm{sj}$ & $395 \mathrm{sj}$. & $\begin{array}{l}\text { Carnestolendas y } \\
\text { Corpus } \text { Christi/88 }\end{array}$ \\
\hline $\begin{array}{c}\text { Miguel Sancho y } \\
\text { Simón de Almança }\end{array}$ & Romanos & 99 sj. $3 \mathrm{~d}$. & 99 sj. 3d. & \\
\hline $\begin{array}{l}\text { Antón de } \\
\text { Mezquita }\end{array}$ & Villarroya & $\begin{array}{l}\text { Luis de Santángel } \\
{\left[\begin{array}{l}64 \mathrm{sj} .] \\
\end{array}\right.}\end{array}$ & $64 \mathrm{sj}$. & \\
\hline Diversos vecinos & Badules & 858 sj. 6 d. & 425 sj. 6 d. & $\begin{array}{l}\text { Carnestolendas y } \\
\text { Corpus } \text { Christi/88 }\end{array}$ \\
\hline Diversos vecinos & Villahermosa & $110 \mathrm{sj} .10 \mathrm{~d}$. & $57 \mathrm{sj} .4 \mathrm{~d}$. & $\begin{array}{l}\text { Carnestolendas y } \\
\text { Corpus Christi/88 }\end{array}$ \\
\hline Diversos vecinos & Burbáguena & $343 \mathrm{sj}$. & $67 \mathrm{sj}$. & $\begin{array}{l}\text { Carnestolendas y } \\
\text { Corpus } \text { Christi/88 }\end{array}$ \\
\hline $\begin{array}{l}\text { Martín Giralt y } \\
\text { Antón Julián, } \\
\text { clérigo }\end{array}$ & Báguena & $\begin{array}{l}\text { Gil de Gonzalo Ruiz y } \\
\text { otros [26 sj. } 10 \mathrm{~d} \text {.] }\end{array}$ & $26 \mathrm{sj} .10 \mathrm{~d}$. & \\
\hline $\begin{array}{l}\text { Miguel de Prebus } \\
\text { y Pedro de Cuellar }\end{array}$ & {$[\ldots]$} & $180 \mathrm{sj}$. & $180 \mathrm{sj}$. & \\
\hline
\end{tabular}

258 «Se obligo por diversas personas y de muchos lugares». 


\begin{tabular}{|c|c|c|c|c|}
\hline Deudor & Localidad & Importe & Ingresos & Aplazamientos \\
\hline $\begin{array}{l}\text { Cristianos y } \\
\text { mudéjares }\end{array}$ & Huesa & $375 \mathrm{sj}$. & $84 \mathrm{sj}$. & Año 1488 \\
\hline Diversos vecinos & Muniesa & 89 sj. 8 d. & $36 \mathrm{sj} .8 \mathrm{~d}$. & \\
\hline Pascual Royo & Blesa & $25 \mathrm{sj}$. & $25 \mathrm{sj}$. & \\
\hline Diversos vecinos & Olalla & $112 \mathrm{sj}$. & $112 \mathrm{sj}$. & \\
\hline Martín de Sancta & Montalbán & $\begin{array}{c}\text { Berenguer Ram } \\
{[271 \mathrm{sj} .]}\end{array}$ & $50 \mathrm{sj}$. & Indeterminado \\
\hline $\begin{array}{c}\text { Jaime de Bella y } \\
\text { la mujer de Antón } \\
\text { Valero }\end{array}$ & Montalbán & $90 \mathrm{sj}$. & $50 \mathrm{sj}$. & Indeterminado \\
\hline Diversos vecinos & Alfambra & $3.566 \mathrm{sj} .4 \mathrm{~d}$. & $2.868 \mathrm{sj}$. & Indeterminado \\
\hline Aljama mudéjar & Gea & 2.705 sj. 2 d. & $1.246 \mathrm{sj}$. & $\begin{array}{c}\text { Navidad/ } \\
88-89\end{array}$ \\
\hline Concejo & Villel & 1.985 sj. 6 d. & $100 \mathrm{sj}$. & $\begin{array}{c}\text { Navidad/ } \\
88-89\end{array}$ \\
\hline Concejo & Cascante & 2.309 sj. 2 d. & $60 \mathrm{sj}$. & $\begin{array}{l}\text { Navidad/ } \\
88-89\end{array}$ \\
\hline $\begin{array}{l}\text { Pascual Gómez y } \\
\text { Mateo Ruvio }\end{array}$ & {$[\ldots]$} & $125 \mathrm{sj}$. & $100 \mathrm{sj}$. & Indeterminado \\
\hline Concejo & Riodeva & $1.521 \mathrm{sj} .8 \mathrm{~d}$. & 174 sj. 3 d. & $\begin{array}{c}\text { Asunción/88 y } \\
\text { Navidad/89 }\end{array}$ \\
\hline Diversos vecinos & Ademuz & $11.192 \mathrm{sj} .6 \mathrm{~d}$. & 2.731 sj. 8 d. & $\begin{array}{c}\text { Asunción/88 y } \\
\text { Navidad/89 }\end{array}$ \\
\hline Concejo & Alpuente & $1.071 \mathrm{sj} .6 \mathrm{~d}$. & $87 \mathrm{sj}$. & $\begin{array}{l}\text { Natividad de la } \\
\text { Virgen } / 88\end{array}$ \\
\hline Martín de Viana & Sinarcas & $\begin{array}{l}\text { Manuel de Puigmija } \\
\text { [ganado vacuno] }\end{array}$ & $177 \mathrm{sj}$. & \\
\hline
\end{tabular}

Tabla 17. Honorarios fijados a los integrantes del tribunal 259

\begin{tabular}{|c|c|c|c|}
\hline Beneficiario & Cargos & Retribución & Observaciones \\
\hline Martín Navarro & Inquisidor & $3.500 \mathrm{sj}$. & \\
\hline Micer Sancho Marín & Asesor & $5.000 \mathrm{sj}$. & Cuando llegue de Valencia \\
\hline Juan Pérez & Notario & $2.500 \mathrm{sj}$. & \\
\hline Domingo Alcaçar ${ }^{260}$ & Notario & $2.000 \mathrm{sj}$. & Desde su incorporación \\
\hline García Rebolledo & Alguacil & $3.500 \mathrm{sj}$. & \\
\hline Pero Pérez & Fiscal & $2.500 \mathrm{sj}$. & Oriundo de Valencia \\
\hline
\end{tabular}

259 Pese a su inclusión en la cautela real, no consta retribución alguna a Sancho Marín o Pedro Pérez, de modo que es plausible que no llegaran a incorporarse. A.R.V., Maestre Racional, reg. 8322, fol. 6r-v.

260 A.H.N., Sección Inquisición, Valencia, leg. 534/16, fol. 14r. 
Tabla 18. Retribuciones percibidas por los funcionarios del tribunal 261

\begin{tabular}{|c|c|c|}
\hline Perceptor & Cargo & Cuantía \\
\hline Martín Navarro & Inquisidor & $2.820 \mathrm{sj}$. \\
\hline Alonso Daça & Escribano de receptoría & $2.650 \mathrm{sj}$. \\
\hline Juan Pérez & Notario & $3.342 \mathrm{sj}$. \\
\hline Juan Claver & Receptor & $3.330 \mathrm{sj} .4 \mathrm{~d}$. \\
\hline García Rebolledo & Alguacil & $3.179 \mathrm{sj}$. \\
\hline Jaime Mora & Asesor & $200 \mathrm{sj}$. \\
\hline Domingo Alcácer & Notario & $500 \mathrm{sj}$. \\
\hline Gil Gracián & Procurador fiscal & $150 \mathrm{sj}$. \\
\hline
\end{tabular}

Tabla 19. Asignaciones para el sustento de familiares de los condenados ${ }^{262}$

\begin{tabular}{|c|c|c|}
\hline Perceptor & Concepto & Cuantía \\
\hline $\begin{array}{c}\text { Rica de Toledo, viuda de } \\
\text { Juan Sánchez de Exarch }\end{array}$ & $\begin{array}{c}\text { Sustento alimenticio de la beneficiaria y de sus } \\
\text { hijos: un cofre con trigo y 8 sueldos }\end{array}$ & $37 \mathrm{sj}$. \\
\hline $\begin{array}{c}\text { Tolosana, mujer de } \\
\text { Alonso de Santángel }\end{array}$ & $\begin{array}{c}\text { Medios materiales para que inicie una nueva vida } \\
\text { en Valencia }\end{array}$ & $100 \mathrm{sj}$. \\
\hline Pedro Díez, mercader & $\begin{array}{c}\text { Tejidos destinados a Alba, hija de Jaime Martínez } \\
\text { de Santángel, para confeccionar sus vestidos }\end{array}$ & $121 \mathrm{sj}$. \\
\hline $\begin{array}{c}\text { Alba, hija de Jaime } \\
\text { Martínez de Santángel }\end{array}$ & Alimento y camisas por valor de 10 florines & $160 \mathrm{sj}$. \\
\hline Rica de Toledo & Un cahíz de trigo para el sustento de su familia & $27 \mathrm{sj}$. \\
\hline Rica de Toledo & Necesidades básicas de manutención & $27 \mathrm{sj} .6 \mathrm{~d}$. \\
\hline
\end{tabular}

Tabla 20. Cantidades percibidos por profesionales o personal auxiliar del tribunal 263

\begin{tabular}{|c|c|c|}
\hline Perceptor & Concepto & Cuantía \\
\hline $\begin{array}{c}\text { Pedro Martínez, correo, } \\
\text { vecino de Teruel }\end{array}$ & $\begin{array}{c}\text { Un viaje portando documentos consignados al rey y } \\
\text { Tomás de Torquemada, y una segunda embajada a } \\
\text { Valencia con cartas destinadas al monarca }\end{array}$ & $72 \mathrm{sj} .^{264}$ \\
\hline Juan de Berbete, correo & $\begin{array}{c}\text { Emisario remitido por los inquisidores de Zaragoza } \\
\text { a los de Teruel portando ciertos procesos de su } \\
\text { Audiencia }\end{array}$ & $32 \mathrm{sj.}$ \\
\hline
\end{tabular}

261 A.R.V., Maestre Racional, reg. 8322, fols. $62 \mathrm{r}-67 \mathrm{v}$.

262 A.R.V., Maestre Racional, reg. 8322, fols. 44v, 47r, 50r-v, 54v y 57.

263 A.R.V., Maestre Racional, reg. 8322, fols. 46v-47r, 48r-52r, 53r, 54r-57r, 58v-59r y $60 v$.

264 A.R.V., Maestre Racional, reg. 8322, fols. 44v-45v y 47r-v. 


\begin{tabular}{|c|c|c|}
\hline Perceptor & Concepto & Cuantía \\
\hline $\begin{array}{l}\text { Antón Sánchez, vicario de } \\
\text { Concud }\end{array}$ & $\begin{array}{l}\text { Crianza de un hijo de Juan Sánchez de Exarch, } \\
\text { ejecutado por la Inquisición }\end{array}$ & $55 \mathrm{sj}$. \\
\hline $\begin{array}{l}\text { Juan de Torremocha, } \\
\text { correo, vecino de Teruel }\end{array}$ & Un desplazamiento a Calatayud & $30 \mathrm{sj}$. \\
\hline Amador de Aliaga & $\begin{array}{l}\text { Detención de García Marzilla y Francisco Garcés de } \\
\text { Marzilla sospechosos de ocultar bienes de conversos }\end{array}$ & $33 \mathrm{sj}$. \\
\hline Amador de Aliaga & $\begin{array}{l}\text { Gastos por la declaración judicial de Domingo } \\
\text { Valero y su hija, vecinos de Mezquita }\end{array}$ & $12 \mathrm{sj}$. \\
\hline Domingo Matheu & $\begin{array}{l}\text { Once álabes para reparar la rueda del molino de } \\
\text { Juan Ruiz }\end{array}$ & $12 \mathrm{sj}$. \\
\hline $\begin{array}{l}\text { Pascual Nadal, vecino de } \\
\text { El Pobo }\end{array}$ & $\begin{array}{c}\text { Arriendo de una cambra donde estuvo almacenada } \\
\text { dos años la cebada de los campos de Luis de } \\
\text { Santángel }\end{array}$ & $12 \mathrm{sj}$. \\
\hline $\begin{array}{l}\text { Gil Martínez, rector de } \\
\text { Cascante }\end{array}$ & $\begin{array}{c}\text { Entrega de unas escrituras que le confiaron los } \\
\text { inquisidores }\end{array}$ & $3 \mathrm{sj}$. \\
\hline Vicario de Tramacastilla & $\begin{array}{c}\text { Diligencias efectuadas en la publicación de diversas } \\
\text { cartas monitorias }\end{array}$ & $3 \mathrm{sj}$. \\
\hline $\begin{array}{l}\text { Martín Sebastián, vecino } \\
\text { de Santa Olaia }\end{array}$ & Custodia de unas yeguas transferidas al rey & $10 \mathrm{sj}$. \\
\hline $\begin{array}{l}\text { Juan de Heredia, vecino de } \\
\text { Daroca }\end{array}$ & $\begin{array}{l}\text { Indagación de las deudas existentes en la Comuni- } \\
\text { dad de Daroca con los judeoconversos de Teruel }\end{array}$ & $50 \mathrm{sj}$ \\
\hline Juan Rubio & $\begin{array}{c}\text { Dietas por } 14 \text { o } 15 \text { días que permaneció en Valencia } \\
\text { presentando provisiones sobre las deudas contraídas } \\
\text { con los herejes de Teruel }\end{array}$ & $60 \mathrm{sj}$. \\
\hline Francisco Bonfill, nuncio & $\begin{array}{l}\text { Entrega de cartas monitorias a la villa de Vilacroche } \\
\text { y otros lugares }\end{array}$ & $10 \mathrm{sj}$. \\
\hline Gonzalo Miguel, nuncio & $\begin{array}{c}\text { Dietas por el viaje a Alfambra y otras aldeas con } \\
\text { monitorias que exhortaban a aflorar deudas con los } \\
\text { conversos de Teruel }\end{array}$ & $12 \mathrm{sj}$. \\
\hline $\begin{array}{c}\text { Diego Vijuescas y } \\
\text { Domingo Alcacer, notarios, } \\
\text { y Francisco Bonfil, nuncio }\end{array}$ & $\begin{array}{l}\text { Testificación de comparecientes y actuaciones } \\
\text { conexas al tribunal }\end{array}$ & $19 \mathrm{sj}$. \\
\hline $\begin{array}{l}\text { Miguel Mateo, vecino de } \\
\text { Ojos Negros, aldea de } \\
\text { Daroca }\end{array}$ & $\begin{array}{l}\text { Jornadas invertidas en Zaragoza y diez cartas de } \\
\text { comanda entregadas al receptor Alonso de Mesa }\end{array}$ & $130 \mathrm{sj}$. \\
\hline $\begin{array}{l}\text { Andrés de Valdezebro, } \\
\text { correo }\end{array}$ & $\begin{array}{c}\text { Entrega al monarca en Salamanca de unas cartas del } \\
\text { tribunal }\end{array}$ & $68 \mathrm{sj}$. \\
\hline $\begin{array}{l}\text { Francisco Bofill, nuncio, } \\
\text { Diego de Vijuescas y Juan } \\
\text { de Moros, notario }\end{array}$ & $\begin{array}{c}\text { Gestiones varias («cosas necesarias al officio de la } \\
\text { Inquisicion») }\end{array}$ & 38 sj. \\
\hline Luis Martínez, notario & $\begin{array}{c}\text { Actuación profesional en la emisión de documentos } \\
\text { requeridos por el tribunal }\end{array}$ & $14 \mathrm{sj}$. \\
\hline Francisco Laparra, labrador & Poda de las heredades de Juan Ruiz y Pedro Ruiz & 26 sj. 3 d. \\
\hline
\end{tabular}




\begin{tabular}{|c|c|c|}
\hline Perceptor & Concepto & Cuantía \\
\hline Juan Martínez, labrador & $\begin{array}{c}\text { Obras realizadas en la casa de Jaime Martínez de } \\
\text { Santángel, mayor }\end{array}$ & $20 \mathrm{sj}$. \\
\hline $\begin{array}{c}\text { Francisco Pérez, notario de } \\
\text { Teruel }\end{array}$ & $\begin{array}{c}\text { Dietas por } 30 \text { días que invirtió en investigar } \\
\text { en Daroca y sus aldeas las deudas con los } \\
\text { judeoconversos de Teruel }\end{array}$ & 178 sj. 8 d. \\
\hline $\begin{array}{l}\text { Miguel de Exea, correo, } \\
\text { habitante en Valencia }\end{array}$ & $\begin{array}{c}\text { Embajada ante el rey y el Inquisidor General sobre } \\
\text { la dinámica del tribunal }\end{array}$ & $154 \mathrm{sj}$. \\
\hline $\begin{array}{c}\text { Mosén Guarín, clérigo de } \\
\text { Teruel }\end{array}$ & $\begin{array}{l}\text { Confección de cuatro efigies relativas a otros tantos } \\
\text { condenados en la hoguera }\end{array}$ & $24 \mathrm{sj}$ \\
\hline $\begin{array}{l}\text { Juan Pérez, notario de la } \\
\text { inquisición }\end{array}$ & $\begin{array}{l}\text { Material de escritorio y otras actividades («paper } \\
\text { por a los processos e cosas necessarias del officio } \\
\text { de la inquisición») }\end{array}$ & $16 \mathrm{sj}$ \\
\hline $\begin{array}{l}\text { Miguel de Vera y Martín } \\
\text { López, fusteros, habitantes } \\
\text { en Teruel }\end{array}$ & $\begin{array}{c}\text { Fabricación de un cadalso para los inquisidores } \\
\text { desde donde leyeron las sentencias de mosén Gil } \\
\text { Ruiz, Alfonso de Santángel, Violante Ruiz y Beatriz } \\
\text { Martínez de Marcilla }\end{array}$ & $16 \mathrm{sj}$. \\
\hline $\begin{array}{l}\text { Domingo Alçacer, notario } \\
\text { de la Inquisición }\end{array}$ & $\begin{array}{l}\text { Actuaciones relativas a la Inquisición («cosas de la } \\
\text { Inquisicion») }\end{array}$ & $21 \mathrm{sj}$ \\
\hline $\begin{array}{l}\text { Miguel Matheu, vecino de } \\
\text { Álava }\end{array}$ & $\begin{array}{l}10 \text { fanegas de trigo por la recaudación de la } \\
\text { primicia del lugar de Álava }\end{array}$ & 55 sj. \\
\hline $\begin{array}{l}\text { Miguel Camanyas, jurista } \\
\text { de Teruel }\end{array}$ & $\begin{array}{l}\text { Asistencia letrada de Santángel, menor, condenado a } \\
\text { la hoguera }\end{array}$ & $80 \mathrm{sj} .[5 \mathrm{fl}]$. \\
\hline Mossé Arripol, judío 265 & Ejecución de una sentencia del inquisidor & $14 \mathrm{sj}$. \\
\hline $\begin{array}{l}\text { Juan Martínez, notario de } \\
\text { Teruel }\end{array}$ & Honorarios por trabajos en la Audiencia de Teruel & $30 \mathrm{sj}$. \\
\hline Mosén Jaime Cabrero & $\begin{array}{l}\text { Honorarios como procurador en las causas de Diego } \\
\text { de Quator y Donosa Besant }\end{array}$ & $40 \mathrm{sj}$. \\
\hline $\begin{array}{l}\text { Juan Gil, corredor de } \\
\text { Teruel }\end{array}$ & $\begin{array}{l}\text { Honorarios por la subasta de heredades y bienes } \\
\text { diversos }\end{array}$ & $42 \mathrm{sj}$ \\
\hline $\begin{array}{c}\text { Convento de San Francisco } \\
\text { de Teruel }\end{array}$ & $\begin{array}{l}\text { Beneficios, misas y obras piadosas que Jaime } \\
\text { Martínez de Santángel y Gil Gonzalo Ruiz } \\
\text { comprometieron con la congregación }\end{array}$ & $2.860 \mathrm{sj}$ \\
\hline Ferrando de Ucaña, pintor & Confección de cuatro efigies para el Auto de fe & $12 \mathrm{sj}$. \\
\hline Pedro Maestre, sastre & Servicios profesionales relativos a su oficio & $20 \mathrm{sj}$ \\
\hline Juan Rubio & Pliegos de papel y material de escritorio & 27 sj. 8 d. \\
\hline Mosén Francisco Allapuz & $\begin{array}{l}\text { Honorarios como miembro del Consejo Asesor en } \\
\text { las sentencias del tribunal }\end{array}$ & $200 \mathrm{sj}$. \\
\hline
\end{tabular}

265 Regidor de la aljama en 1480 junto a Açach Calvo y Salamón Benalrabi, cuando obtienen licencia del concejo para adquirir 9 cargas de vino «judayquo para lur provision» hasta marzo, y de ahí en adelante 7 cargas mensuales. El cargo lo vuelve a asumir once años después. A.H.P.T., Sección Concejo, Actos Comunes, 1479-80, fol. 57v y Liber procurationis, 1491, fol. 17r. 


\begin{tabular}{|c|c|c|}
\hline Perceptor & Concepto & Cuantía \\
\hline $\begin{array}{c}\text { Juan de Moros, notario de } \\
\text { Teruel }\end{array}$ & Escritura en un proceso incoado a Juan de Santángel & $28 \mathrm{sj.} .266$ \\
\hline $\begin{array}{c}\text { Francisco Pérez, alguacil } \\
\text { García Medina, nuncio } \\
\text { Comunidad de Teruel y Daroca, exigiendo el } \\
\text { afloramiento de deudas con los conversos de Teruel }\end{array}$ & $119 \mathrm{sj.}$ \\
\hline $\begin{array}{c}\text { Servicios prestados al tribunal } \\
\text { Domingo el Vaio, vecino } \\
\text { de Sarrión }\end{array}$ & $\begin{array}{c}\text { Detención de la mujer de un médico castellano } \\
\text { sospechoso de herejía en Sagunto y traslado a } \\
\text { Teruel y Zaragoza }\end{array}$ & $100 \mathrm{sj.}$ \\
\hline $\begin{array}{c}\text { Luis Martínez, notario de } \\
\text { Teruel }\end{array}$ & $\begin{array}{c}\text { Escrituras expedidas a instancia del procurador } \\
\text { fiscal }\end{array}$ & $42 \mathrm{sj.}$ \\
\hline $\begin{array}{c}\text { García de Heredia, vecino } \\
\text { de Teruel }\end{array}$ & $\begin{array}{c}\text { Derechos de un quinquenio sobre la capellanía de su } \\
\text { hijo, con un censo anual de 75 sueldos, y 5 sueldos } \\
\text { sobre unas casas de Martínez de Santángel, mayor, } \\
\text { en la Plaza Mayor }\end{array}$ & $350 \mathrm{sj.}$ \\
\hline
\end{tabular}

Tabla 21. Salarios pendientes del servicio doméstico de las familias conversas $^{267}$

\begin{tabular}{|c|c|c|c|}
\hline Vivienda & Servicio doméstico & Localidad & Salario \\
\hline Alfonso Santángel & Benedicta Yagüe & {$[$ Teruel] } & $60 \mathrm{sj}$. \\
\hline Berenguer Ram & Lucía Asensio & Caudé & $150 \mathrm{sj}$. \\
\hline Berenguer Ram & Juana Anguita & {$[$ Teruel] } & $150 \mathrm{sj}$. \\
\hline Diego de Toledo & Catalina Calvo & Monteagudo & $130 \mathrm{sj}$. \\
\hline Donosa Gracián & Catalina Mata & {$[$ Teruel] } & $65 \mathrm{sj}$. \\
\hline Francisco de Puigmija & Violante Ramo & {$[$ Teruel] } & $25 \mathrm{sj}$. \\
\hline Gil de Gil Ruiz & Pascuala Lecina & {$[$ Teruel] } & $100 \mathrm{sj}$. \\
\hline Gil Ruiz & Pascuala Rodríguez & Albarracín & $100 \mathrm{sj}$. \\
\hline Jaime Martínez de Santángel, mayor & Teresa Gómez & {$[$ Teruel] } & $50 \mathrm{sj}$. \\
\hline Jaime Martínez de Santángel, mayor & Juana Díaz & Tramacastilla & $150 \mathrm{sj.}$ \\
\hline Jaime Martínez de Santángel, mayor & Catalina Laguía & {$[$ Teruel] } & $25 \mathrm{sj.}$ \\
\hline Manuel de Puigmija & María Escovedo 268 & Utrillas & $30 \mathrm{sj.}$ \\
\hline Manuel de Puigmija & Catalina García & El Castellar & $70 \mathrm{sj.}$ \\
\hline
\end{tabular}

266 Equivalente a 1 castellano de oro.

267 A.R.V., Maestre Racional, reg. 8322, fols. 50r, 52r-53r, 54r, 56r y 57v-58r.

268 Correspondiente a la prestación de servicios durante un año. 
Tabla 22. Censos sobre inmuebles abonados por los judios a instituciones religiosas 269

\begin{tabular}{|c|c|c|c|c|c|}
\hline Perceptor & Arrendatario & Inmueble & Ubicación & Valor & Vencimiento \\
\hline $\begin{array}{l}\text { Cosme Trullols, } \\
\text { clérigo de S. Pedro }\end{array}$ & $\begin{array}{l}\text { Gil Ruiz, el } \\
\text { Dentudo }\end{array}$ & $\begin{array}{l}\text { Caballeriza } \\
\text { y granero }\end{array}$ & {$[\ldots]$} & $20 \mathrm{sj}$. & S. Miguel/85-6 \\
\hline $\begin{array}{l}\text { Cosme Trullols, } \\
\text { clérigo de S. Pedro }\end{array}$ & $\begin{array}{c}\text { Jaime de } \\
\text { Santángel, mayor }\end{array}$ & Huerto & Mulatilla & $20 \mathrm{sj}$. & S. Miguel \\
\hline $\begin{array}{l}\text { Cosme Trullols, } \\
\text { clérigo de S. Pedro }\end{array}$ & $\begin{array}{c}\text { Jaime de } \\
\text { Santángel, mayor }\end{array}$ & Huerto & $\begin{array}{l}\text { Puente de na } \\
\text { Alnira }\end{array}$ & $8 \mathrm{sj}$. & S. Miguel \\
\hline $\begin{array}{c}\text { Cosme Trullols, } \\
\text { clérigo de S. Pedro }\end{array}$ & $\begin{array}{c}\text { Jaime de } \\
\text { Santángel, mayor }\end{array}$ & Casas & $\begin{array}{c}\text { Carrera de } \\
\text { Zaragoza }\end{array}$ & $10 \mathrm{sj}$. & S. Luis/85-6 \\
\hline $\begin{array}{l}\text { Cosme Trullols, } \\
\text { clérigo de S. Pedro }\end{array}$ & $\begin{array}{l}\text { Juan Sánchez } \\
\text { Exarch }\end{array}$ & Casas & $\begin{array}{c}\text { Carrera } \\
\text { Domingo } \\
\text { Sadornil }\end{array}$ & $5 \mathrm{sj}$. & S. Miguel/85-6 \\
\hline $\begin{array}{l}\text { Cosme Trullols, } \\
\text { clérigo de S. Pedro }\end{array}$ & Pedro Ruiz & Casas & $\begin{array}{l}\text { Carrera de } \\
\text { S. Pedro }\end{array}$ & $20 \mathrm{sj}$. & $\begin{array}{l}\text { Santos } \\
\text { Inocentes }\end{array}$ \\
\hline Iglesia de S. Miguel & Aldonza Besant & Casas & Concud & $6 \mathrm{sj}$. & Cuaresma/87 \\
\hline $\begin{array}{c}\text { Monasterio de la } \\
\text { Merced }\end{array}$ & Familia Ruiz & Inmuebles & Teruel & $30 \mathrm{sj}$. & Marzo/86-7 \\
\hline $\begin{array}{l}\text { Monasterio de la } \\
\text { Merced }\end{array}$ & Aldonza Besant & Heredad & {$[\ldots]$} & 40 sj. & $\begin{array}{c}\text { S. Jorge/ } \\
86-7 \\
\end{array}$ \\
\hline Iglesia de S. Pedro & Aldonza Besant & Casas & Concud & $6 \mathrm{sj}$. & S. Miguel/87 \\
\hline Iglesia de S. Pedro & $\begin{array}{l}\text { Francisco } \\
\text { Puigmija }\end{array}$ & Casas & $\begin{array}{c}\text { Carrera } \\
\text { Puerta de } \\
\text { Zaragoza }\end{array}$ & $30 \mathrm{sj}$. & {$[\ldots]$} \\
\hline Iglesia de S. Pedro & Pedro Ruiz & Huerto & Cofiero & $10 \mathrm{sj}$. & {$[\ldots]$} \\
\hline Iglesia de S. Martín & $\begin{array}{c}\text { Jaime de } \\
\text { Santángel, mayor }\end{array}$ & Casas & Morería & $17 \mathrm{sj}$. & 1487 \\
\hline Iglesia de S. Martín & $\begin{array}{c}\text { Jaime de } \\
\text { Santángel, mayor }\end{array}$ & $\begin{array}{l}\text { Heredad y } \\
\text { casas }\end{array}$ & Tortajada & $50 \mathrm{sj}$. & $\begin{array}{l}\text { Septiembre/ } \\
85-6\end{array}$ \\
\hline Iglesia de S. Martín & $\begin{array}{c}\text { Jaime de } \\
\text { Santángel, mayor }\end{array}$ & Casas & $\begin{array}{l}\text { Carrera de } \\
\text { Zaragoza }\end{array}$ & $10 \mathrm{sj}$. & Cuaresma/85 \\
\hline Iglesia de S. Martín & $\begin{array}{c}\text { Jaime de } \\
\text { Santángel, mayor } \\
\end{array}$ & Casas & Arrabal & $10 \mathrm{sj}$. & S. Antón/85 \\
\hline Iglesia de S. Martín & $\begin{array}{c}\text { Jaime de } \\
\text { Santángel, mayor }\end{array}$ & Casas & Morería & $20 \mathrm{sj}$. & S. Miguel/85-6 \\
\hline Iglesia de S. Martín & $\begin{array}{c}\text { Aldonza de } \\
\text { Besant }\end{array}$ & $\begin{array}{c}\text { Parcela de } \\
\text { tierra }\end{array}$ & {$[\ldots]$} & $3 \mathrm{sj}$. & S. Miguel/86 \\
\hline Iglesia de S. Pedro & $\begin{array}{l}\text { Gil Ruiz, el } \\
\text { Dentudo }\end{array}$ & $\begin{array}{l}\text { Caballeriza } \\
\text { y granero }\end{array}$ & {$[\ldots]$} & $20 \mathrm{sj}$. & S. Miguel/86 \\
\hline
\end{tabular}

269 A.R.V., Maestre Racional, reg. 8322 , fols. $45 \mathrm{v}-46 \mathrm{v}, 49 \mathrm{r}-\mathrm{v}, 55 \mathrm{r}, 58 \mathrm{v}$ y $60 \mathrm{r}$. En lo que respecta a su ubicación, salvo que se indique lo contrario, se enclavan en Teruel. 


\begin{tabular}{|c|c|c|c|c|c|}
\hline Perceptor & Arrendatario & Inmueble & Ubicación & Valor & Vencimiento \\
\hline Iglesia de S. Pedro & $\begin{array}{c}\text { Gil Ruiz, el } \\
\text { Dentudo }\end{array}$ & $\begin{array}{c}\text { Caballeriza } \\
\text { y granero }\end{array}$ & {$[\ldots]$} & $20 \mathrm{sj}$. & S. Miguel/87 \\
\hline Iglesia de S. Pedro & Pedro Ruiz & $\begin{array}{c}\text { Casas y } \\
\text { bodega }\end{array}$ & {$[\ldots]$} & $20 \mathrm{sj}$. & S. Miguel/87 \\
\hline Iglesia de S. Pedro & Pedro Ruiz & Casas & $\begin{array}{c}\text { Calle de } \\
\text { S. Pedro }\end{array}$ & $20 \mathrm{sj}$ & $\begin{array}{c}\text { Santos } \\
\text { Inocentes }\end{array}$ \\
\hline Iglesia de S. Pedro & $\begin{array}{c}\text { Jaime de } \\
\text { Santángel, mayor }\end{array}$ & Casas & $\begin{array}{c}\text { Puerta de } \\
\text { Zaragoza }\end{array}$ & $10 \mathrm{sj}$. & S. Luis/87 \\
\hline Iglesia de S. Pedro & $\begin{array}{c}\text { Juan Sánchez de } \\
\text { Exarch }\end{array}$ & Casas & $\begin{array}{c}\text { Carrera } \\
\text { Domingo } \\
\text { Sadornil }\end{array}$ & $5 \mathrm{sj.}$ & S. Miguel/87 \\
\hline
\end{tabular}

Tabla 23. Balance contable del tribunal de la Inquisición de Teruel $(1487-91)^{270}$

\begin{tabular}{|c|c|c|c|}
\hline Período & Ingresos & Pagos & Saldo \\
\hline $13.11 .1486 / 31.12 .1487$ & 113.724 sj. 2 d. ${ }^{271}$ & 113.449 sj. 4 d. ${ }^{272}$ & +274 sj. $10 \mathrm{~d}$. \\
\hline $01.01 .1488 / 28.02 .1489$ & $143.257 \mathrm{sj} .10 \mathrm{~d}$. & $123.612 \mathrm{sj} .8 \mathrm{~d}$. & $+19.645 \mathrm{sj} .2 \mathrm{~d}$. \\
\hline $01.03 .1489 / 28.02 .1490$ & $76.235 \mathrm{sj} .9 \mathrm{~d}$. & $49.100 \mathrm{sj} .6 \mathrm{~d}$. & $+27.135 \mathrm{sj} .3 \mathrm{~d}$. \\
\hline $01.03 .1490 / 04.11 .1491$ & $\begin{array}{c}103.428 \mathrm{sj} .10 \mathrm{~d} . \\
11.600 \text { sv. } 273\end{array}$ & $\begin{array}{c}104.566 \mathrm{sj} .11 \mathrm{~d} . \\
740 \mathrm{sv} .10 \mathrm{~d} .\end{array}$ & $\begin{array}{c}-1.138 \mathrm{sj} .1 \mathrm{~d} . \\
+10.864 \mathrm{sv} .2 \mathrm{~d} .\end{array}$ \\
\hline
\end{tabular}

Tabla 24. Sinopsis de los ingresos generados por los bienes de los conversos

\begin{tabular}{|c|c|c|}
\hline Converso & Tasación & Ingresos \\
\hline Jaime Martínez de Santángel & $32.710 \mathrm{sj} .9 \mathrm{~d}$. & $30.728 \mathrm{sj} .3 \mathrm{~d}$. \\
\hline Juan Ruiz, el Generalero & $7.461 \mathrm{sj}$. & $5.161 \mathrm{sj}$. \\
\hline Pedro Ruiz & $2.152 \mathrm{sj}$. & $2.152 \mathrm{sj} .10 \mathrm{~d}$. \\
\hline Francisco Martínez de Rueda, alias Tristán & $9.618 \mathrm{sj} .2 \mathrm{~d}$. & $9.618 \mathrm{sj} .2 \mathrm{~d}$. \\
\hline Gil Ruiz el Dentudo & $1.875 \mathrm{sj} .2 \mathrm{~d}$. & $1.629 \mathrm{sj} .2 \mathrm{~d}$. \\
\hline
\end{tabular}

${ }^{270} C f$. las auditorías en A.R.V., Maestre Racional, reg. 8322, fols. 82r-84r; reg. 8313, fols. $88 \mathrm{r}-90 \mathrm{r}$; reg. $8330-3$, fols. $30 \mathrm{v}-32 \mathrm{v}$ y reg. $12092-4$, fols. $37 \mathrm{v}-39 \mathrm{r}$.

271 Se advierte una levísima desviación entre ambos: 113.724 sueldos 2 dineros (Luis Martínez Cano) y 113.723 sueldos 7 dineros (Alonso Daça).

272 Tras la compulsa minuciosa de los asientos del original, nuestro sumatorio se eleva a 113.448 sueldos 4 dineros jaqueses, es decir, apreciamos una desviación, salvo error u omisión por nuestra parte, de 1 sueldo. A.R.V., Maestre Racional, reg. 8322, fol. $68 \mathrm{r}-\mathrm{v}$.

273 Sueldos reales de Valencia. 


\begin{tabular}{|c|c|c|}
\hline Converso & Tasación & Ingresos \\
\hline Francés de Puigmija & $675 \mathrm{sj}$. & $675 \mathrm{sj}$. \\
\hline Gonzalo Ruiz y su hijo Gil de Gonzalo & 4.679 sj. 4 d. & $3.566 \mathrm{sj} .4 \mathrm{~d}$ \\
\hline Berenguer Ram e hijos & $30.132 \mathrm{sj} .7 \mathrm{~d}$. & 20.981 sj. 8 d. \\
\hline Pedro Pomar & $450 \mathrm{sj}$. & 332 sj. \\
\hline Luis Martínez de Santángel & $3.092 \mathrm{sj}$. & 2.760 sj. 2 d. \\
\hline Juan Sánchez Exarch, alias Royo & 62 sj. $8 \mathrm{~d}$. & 62 sj. 8 d. \\
\hline Diego de Toledo & 2.106 sj. $6 \mathrm{~d}$. & $2.106 \mathrm{sj} .6 \mathrm{~d}$ \\
\hline Juan de Toledo & 603 sj. & $603 \mathrm{sj}$. \\
\hline Martín Ruiz & 365 sj. 3 d. & 365 sj. 3 d. \\
\hline Aldonza Besant & $2.620 \mathrm{sj}$. & $1.600 \mathrm{sj}$. \\
\hline Gracia Ximénez, viuda de Fernando Ram & 229 sj. 9 d. & 189 sj. 3 d. \\
\hline Donosa Gracián & 4.315 sj. $8 \mathrm{~d}$. & 3.515 sj. $8 \mathrm{~d}$ \\
\hline Donosa Ruiz & 787 sj. 6 d. & 393 sj. 9 d. \\
\hline Herejes condenados de Teruel & $56.537 \mathrm{sj} .8 \mathrm{~d}$. & $27.283 \mathrm{sj} .6 \mathrm{~d}$. \\
\hline Total & 160.474 sj. & 113.724 sj. 2 d. \\
\hline
\end{tabular}

Tabla 25. Desglose de los gastos ordinarios y extraordinarios del tribunal

\begin{tabular}{|c|c|c|}
\hline Concepto & Cuantía & Porcentaje \\
\hline Salarios y suplidos & $16.173 \mathrm{sj} .11 \mathrm{~d}$. & $14,26 \%$ \\
\hline Asignaciones asistenciales & $472 \mathrm{sj} .6 \mathrm{~d}$. & $0,42 \%$ \\
\hline Mercedes reales & $17.025 \mathrm{sj} .4 \mathrm{~d}$. & $15,01 \%$ \\
\hline Financiación de la guerra de Granada & $69.000 \mathrm{sj}$. & $60,82 \%$ \\
\hline Servicios profesionales y personal auxiliar & $5.261 \mathrm{sj} .7 \mathrm{~d}$. & $4,64 \%$ \\
\hline Soldada del servicio doméstico & $1.105 \mathrm{sj}$. & $0,97 \%$ \\
\hline Abono de mercancías & $1.000 \mathrm{sj}$. & $0,88 \%$ \\
\hline Censales sobre inmuebles & $410 \mathrm{sj}$. & $0,36 \%$ \\
\hline Amortización de préstamos & $3.000 \mathrm{sj}$. & $2,64 \%$ \\
\hline Total & $113.448 \mathrm{sj} .4 \mathrm{~d}$. & $100 \%$ \\
\hline
\end{tabular}

